示- 1 幽門狭窄症状を有する胃癌症例の臨床病 理学的検討

公立八好総合病院外科

大旧隼二, 納富昌徳, 徳原宏治, 犬塚清久,

丸芣昌文, 田中喜久

胃部膨満，煰気および煰吐を主訴の(いわゆる幽門 狭窄症状)胃癌患者は進行例が多く，一般に予後不良 と思われる．幽門狭窄症状を有する A 領域胃癌症例の 臨床病理学的特幑について検討を行ったので報告する。 過去12年閒で幽門狭䆶症状を有する32例(5.7\%)を対 象とした．平均年令は70.0歳で，75歳以上が $34 \%(11 / 3$ 2)を占めた，術前，低蛋白血症を75\%(24/32)，貧血を 59\%(19/32)に認めた。手術は幽門側胃切が56\%(18/32) と多かったが, 非切除・バイバス術が34\%(11/32)にも

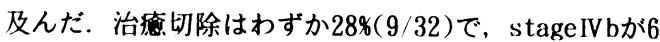
$5.6 \%$ 占めた. 非切除の理由は, 癌腫の膵頭部への直 接浸閵75\%(9/12)が多く，胃切症例の43\%(9/21)に組織 学的十二指腸浸潤を認めた。 さらに，十二指腸断端陽 性は24\%(5/21)で, 断端陽性のみで非治瘾切除に至っ た症例はなかった．また, $\mathrm{D}$,以上症例で $\mathrm{n}_{0}$ はなく, $\mathrm{n} 2$ 以上を $75 \%(9 / 12)$ に認めた.

幽門狭窄症状を有する胃癌症例は高齢者が多く，筷 養状態の低下した例が多かった，また，非治癒切除症 例が多く，十二指腸断端陽性例も多かった。

示- 2 根治手術不能胃癌に対する姑息的切除の 適応についての臨床的検討

藤沢市民病院外科

森脇義弘、小林俊介、山腰英紀、長堀優、今井信介、 城戸泰洋、笠岡千孝

(目的)根治手術不能胃燩に対する手術の指針、特に 姑息的切除の適応を検討するため過去の症例について 㛟討した。対象と方法110年間に姑息的手術を行った stage 4 胃癌症例272例について、幽門側と喷門側にわ け、(姑息的)切除群と非切除群の予後を比較した。結 果と考察1(1)門側：切除群(姑息的胃切除)は74例、 非切除群(胃空晹吻合)は72例であった。P-H+例の平均 生存期間は各487日、174日と切除群で有意に長期であ つたが、P+H-例では統計学的有意差はなかった。P+H 例では両群間に有意差はなく、P-H-例でも1年生存率 では切除群が良好な傾向にあったが、平均生存期間で は差がなかった。術中抗症詴投与の有無别にみても同 様の傾向であった。(2)嘖門側：切除群(姑息的胃全摘) は63例、非切除群(単開腹、胃瘦造設)は36例であった。 $\mathrm{P}$-H十例の平均生存期间は各734日、247日と切除群で長 期の傾向にあったが、P $+\mathrm{H}-$ 例では㧤計学的有意差はな かった。根治手術不能胃瘦では、非治恣因子がP因子 の場合には、生存期間の面での姑息的切除の効果は少 なく、切除の適応は慎重であるべきと思われた。

\section{示-3 内視鏡による邂及的钼寮からみた進展の速 い胃癌、遅い胃癌の比較検討}

\author{
福井県立病院外科 ${ }^{11}$
}

林 裕之、細川治、确下徹哉、白崎信二、谷川 裕、 渡辺国重、津田昇志 ${ }^{1)}$

【目的】内視鏡所見を検討し、進展の速い胃癌、遅 い胃㿋を抽出し検討した。【方法】過去 15 年間に当施 設では、前回の内視鏡検査で全く病変が認められない 状態から、4 年以内に進行癌が発生したものが14例、 また前回の内視鏡検査で癌を疑い得る所見を有してい ながら 2 年以上経過しても早期癌であったものが11例 存在した。前者を進展の速い胃癌、後者を進展の遅い 胃癌として、臨床病理学的検討、および免疫組織学的 検討を行った。【成績】進展の速い胃癌は、男女差は なく、体部腺領域の浸潤型低分化腺㿋に多く、PCN A 標識率、p53 蛋白発現率も高い傾向を認めた。また若 年女性に発生を認める事が注目された。これに対し進 展の遅い胃癌は男性の幽門前庭部付近の陥山型痹が多 く、分化型癌が中心であり、PCN A 標識率、p53蛋白 発現頻度も低かった。【結論】進展の速い胃癌は遅い 胃癌に比し増殖能は高く、その進展には癌遗伝子の発 現および各種増殖因子が関与している事が推察された。

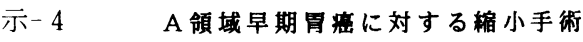

\section{群馬大学第 2 外科}

岩波弘太郎，大和田進，川島吉之, 中村正治 泉勝，小川哲史，佐藤啓宏，官沢直榯，洎下缼和 森下靖雄

当教室では, $\mathrm{A}$ 領域早期胃爱に対し $4 \mathrm{sb}$ 郭清の樎小と，

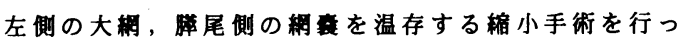
ている。今回, 樎小手術症例 27 例について, 肉眼型,

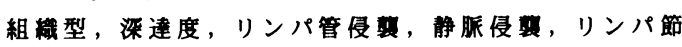
転移状況について娭討した。又，樎小手術例と，非縮 小手術 35 例との間で，手術時間，出血畺について比較 梚討した。樎小手術 27 例の原発单の大きさは, 平均 $2.7 \times 1.9 \mathrm{~cm}$ で, 肉眼型は II c型, 組樴型は高分化型管状 腺虫が高事であった。深達度は, 睰が半数以上を占 めていた。リンパ管侵要, 静脈侵意は, 深達度が增す につれて晹性のものがみられた。リンパ節転移は，組

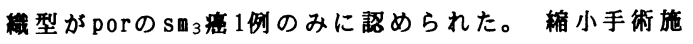
行例の平均手術時間は 3 時間 20 分で, 非樎小手術例の平 均 3 時間 45 分に比べ短樎していた。檘小手術例の平均 出血量は311gで, 非樎小手術例の平均 $467 \mathrm{~g}$ に比べ少量 であった。現在, 再発例はない。 $\mathrm{A}$ 領域に限局した 早期胃惠に，4sb郭清の省略と，左側の大網，椫尾側の 網鿓を温存する維小手術は，手術侵豆を減らし， Q O L 向上の点からも有用である。 
示- 5 リンハ節転移を有する胃粘膜内癌 4 例の検讨

獨協医科大学越谷病院外科

藤田正幸, 佐々木勝海, 岩見 昇, 中村哲郎,

大矢正俊，寺田春彦，赤尾周一，石川 宏

早期胃癌に対する治療法の適応を明確にするため胃粘膜内

癌のリンパ節転移症例の検討を行った。1984年6月より1994 年 5 月までの 10 年間に当科で切除された胃粘膜内痹114例を 対象とした。粘膜内癌でリンパ節転移を認めたのは4例 (35 \%)であった。

症例 $1 ;$;2歳 女性, tub 2, ly 1, v 0, n 1, M, 4×3.5, II c. 症例 2 ; 44歳 女性, por, ly 0, v 0, n 1, C, $5 \times 4.5$, II c. 症例 $3 ; 48$ 歳 男性, por, ly 0, v 0, n 1, C, $4 \times 4$, II c. 症例 4 ; 64歳 男性, por, ly $0, \mathrm{v} 0, \mathrm{n} 2, \mathrm{~A}, 9 \times 7.5$, II c. 腫場長径では転移例 $5.5 \pm 2.4 \mathrm{~cm}$ 、陰性例 $1.8 \pm 0.9 \mathrm{~cm}$ 之有意

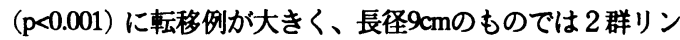
八節(No8)にも転移を認め、長径3.5cm以下の应例 (961例) には リンパ節転移は認めなかった。組織型では分化型よりも未分 化型に多い傾向 $(\mathrm{p}=0.09)$ がみられた。肉眼病型では転移例は すへて陥凹型であった。胃粘膜内癌の再発・死亡例はなかっ た。内視鏡的切除は宿凹を伴わない $3.5 \mathrm{~cm}$ 以下の症例まで道 応を搪大できる可能性があり、4cm以上の症例ではtub 1であ ればリンパ節廊清の縮小化 (D1) か可能で、それ以外の症例 ではD1+7番，8番の廊清が必要と思われた。

\section{示- 6 A F P 産生 II c 型早期胃癌の 1 例} 町立富来病院外科 ${ }^{11}$ ，金沢大学第 1 外科 ${ }^{21}$

椅本㙇生 ${ }^{1)}$, 大村健二 ${ }^{2)}$

alpha-fetoprotein (以下A F P) 産生胃癌のほ亡 んどは進行癌であり、早期癌はまれで本邦から約20例 が報告されているにすぎない。今回われわれは術後 1 年で旰転移再発をきたしたA F P 産生早期胃癌を経挽 したので報告する。

症例は74歳の男性で、食欲不振を主訴に来院した。 胃X線・内視鏡検查で胃角部後壁の II c 型早期胃癌之 診断し、1992年12月17日第 2 群 jンパ節郭清を伴う幽 門侽胃切除術を施行した。病変の大きさは $2.3 \times 2.0 \mathrm{~cm}$ で、病理組織学的には乳頭状に増殖する高分化型管状

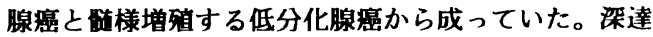

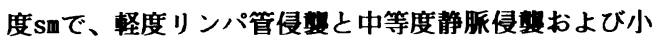
海リンパ節への転移を認めた。肝転移、腹膜転移は認 めなかった。退院後はUF T 400mg/dayの経口投与で 経㝵穓察していた。術後 1 か月では正常值であった血 中腫国マーカーが次第に上昇し、術後 1 年では A F P $209.2 \mathrm{ng} / \mathrm{ml}$, C E A $99.0 \mathrm{ng} / \mathrm{ml}$ と高值となり、腹部超 音波およびC T検查で多発性肝転移が明らかとなった。 そこで、胃癌組織を免度学的に検索したところ A F P の局在が証明された。化学寮法が奏効し、術後 1 年 9 か月を経過した現在、外来にて継続化療中である。
示-7 A F P 産性早期胃知の 1 例

健康保険諌早総合病院外科 ${ }^{1}$, 長崎大学原謴資料セン 夕一病理部 2)

中崎隆行 ${ }^{11}$, 飛永晃二1', 武富勝郎 ${ }^{1}$, 君野孝二1',

仲宗根朝紀 ${ }^{1)}$.岸川正大 $\left.{ }^{2}\right)$

A F P 産性胃癌の全胃㿋に占める割合は3.5-8.8\% と 報告されているが.その多くは進行胃政であり。早期冒

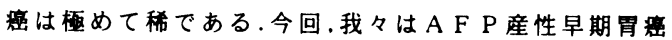
の1例を経虽したので報告する。症例は57歳男性で。 1994 年 2 月頃より心窝部痛出現し 5 月. 近医受診した.上

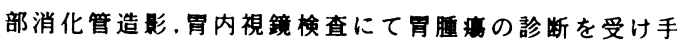
術目的に当科入院となった。入院時検査では，AF P か $17208 \mathrm{ng} / \mathrm{m} 1$ と著明に上昇していた。胃内視鏡検查で胃前

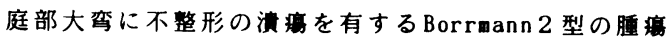

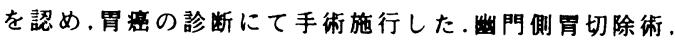
Billroth II 法による再建を行った. $\mathrm{H}_{0}, \mathrm{P}_{0} . \mathrm{T}_{2} . \mathrm{N}_{1}$. Stage II . D 2, 根治度 A であった.切除標本では前庭部大 弯に $3.0 \times 4.0 \mathrm{~cm}$ のBorrmann 2 型病変を認めた。組織学的 所見では異型細胞が中等度に分化し腺管を形成してお り深達度はsmで,tub2.1y3,v3,n1,stage I bであり，免疫 組織染色ではAF P 陽性であった.血清 A F P は術後 1 週目に $3016 \mathrm{ng} / \mathrm{ml}$ ，4週目に $410 \mathrm{ng} / \mathrm{ml}$ と渐娍している.A

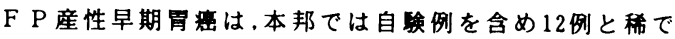
あり文献的考察を含め報告する。

示- 8 脾転移の A F P 産生残胃症の1切除例 いわき市立総合磐城共立病院外科1) 内科2)病理科3) 高橋 優1), 伊藤卓資, 平岡邦彦, 阿部 裕, 横田 隆, 阿部道夫, 伊藤順造, 渡部秀一, 九里孝雄, 里見孝弘, 新井元順, 佐々木高志2), 望月 衛3)

症例は59葴の男性、平成 4 年 10 月上腹部痡を訴之 受診。既往歷：約30年前に十二指腸潰場で幽門側胃切 除術。残胃に大きな腫瘤型腫瘍を認め、血清 AFP $8,000 \mathrm{ng} / \mathrm{ml}$ 示し、生検組織診で腺軠、AFP 陽性、 HCG 陽性と診断した。腹部C Tおよびエコーで脾䏸 に内部不均一な腫瘍性病変を認めた。治療は F P 療法

(5.FU $800 \mathrm{mg} / \mathrm{day}, \mathrm{iv}$, CDDP $35 \mathrm{mg} / \mathrm{day}$, iv, 五日 間）を4ク・ル実施し、AFP值は暫時低下した。平成6 年 5 月 30 日、左第 6 肋間開胸開腹にて残胃全摘術、膵 尾側切除術、脾滕摘出術、胆摘術を施行した。胃腫湯 は約 $8 \times 6 \mathrm{~cm}$ の棈円形の溃瘍浸潤型で、所属リンパ節腫 脤や腹膜播種、肝転移は認めなかった。脾䏚腫瘍は 径 $2 \mathrm{~cm}$ 大の黄色調の軟らかい腫瘍であった。胃腫堭の 病理組織像では、㿋組織の大部分は中分化型管状腺㿋 の像を呈したが、一部に㿋細胞の充実性ないしシート 状の増殖巣が混在していた(ss $\beta, v 3,1 y 3, n 0) 。$ 脾腫瘍 は壊死租織であった。術後3力月現在、外来通院中で あるが、AFPは正常で、再発の兆候もない。 
示-9 血清Alpha-fetoprote in陽性胃癌の細胞増 殖活性および基底膜形成からみた臨床病理学的特徽 岐皁大学第二外科 ${ }^{11}$ 、同臨床検査医学 ${ }^{21}$

国枝克行 ${ }^{11}$ 、佐治重豊、川口順敬、梅本敬夫、宮 喜一、深田代造、稲田 潔 ${ }^{2)} 、 下 川$ 邦泰 $^{2)}$

【目的】血清AFP陽性胃癌の臨床病理学的特徽をとくに 細胞増殖能と基底膜形成の観点から検討した。【対象と 方法】1981年以降に䅅験した血清AFP陽性例16例

(2.2\%)を対象として、PCNA、LamininおよびAFP免疫組 織染色を $\mathrm{ABC}$ 法を用いて行った。【結果】16例 (stage I $a+I b$ 5例、II 1例、II $a+I I b$ 3例、 $N a+I V b$ 7例)の肉眼 型は2型が8例 (50\%) と最も多く、AまたはAM領域に12例 (75\%)が占居していた。組織型ではpoor medullaryを呈 した症例が7例 (43.8\%) と有意に高頻度であった。転移 形式ではP (+)例が1例 (6.3\%)であったのに対し、H(+)例 が6例 (37.5\%) とAFP㓌性群に比べ有意に多かった。5年 生存率は37.5\%で、stage I a と II の2症例が肝転移再発 にて死亡した。AFP染色陽性率は81.3\%であった。PCNA 標識率は、AFP㓌性群の平均が44.1であったのに対し、 陽性群では63.9と有意に高值を示した。AFP陽性群の Laminin陽性率は81.3\%であり㓌性群での42.2\%に比べ 有意に高率であった。【結語】血性AFP陽性胃癌は㓌性 群に比べ有意に増殖活性、Laminin染色率が高く、肝転 移頻度が高いという特徵との関連性が示唆された。

示一10一卵性双生児に発症した周星の一家系と田

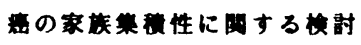
科 21

金沢大学がん研究所外科 "、成田赤十字病院外

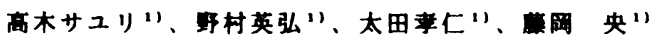

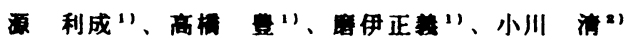

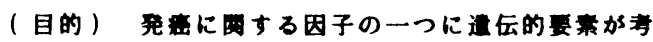

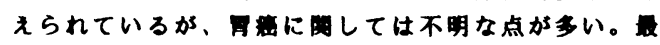
近われわれは一邲性双生呪に発症した可副の一家系を

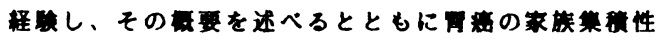
の間さも含め湌暏した。

（対稣と方法）1989年〜1994年8月31日までに当科で

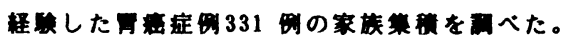

（庭1）45才、女性. 同のA、circに7x4c=の3型低

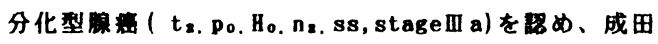

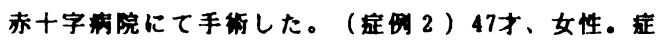

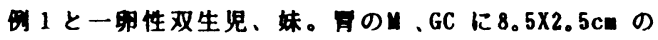
IIc 型低分化型照（sig. po. Ho, no, sm,stage I a)

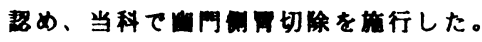

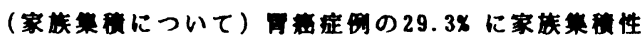
が見られ、同露家系においては消化器系の重の必要 性が䇰鬼された。

\section{示-11噴門部癌食道浸淍例の検討}

山形県立中央病院外科

福島紀雅, 高橋閨, 東敬之, 大江麻子, 渋間久, 池田栄一

【対象】1983年から1992年の10年間における噴門部 癌（病巣の中心がEC」より2.0 cm以内にあるもの）96例 中, 食道浸閏例54例対象とし, 食道浸閏距離, 食道浸 閏形式を他の臨床病理学的諸因子と比較検討した。

【結果】平均食道浸閏距離は早期癌 $6.9 \mathrm{~mm}$, B o r 1,2 型 $16.1 \mathrm{~mm}, B 0 \mathrm{r} 3,4$ 型 $31.2 \mathrm{~mm}$ てあり, 早期癌ては $15 \mathrm{~mm}$ 以上の浸閏例は認められなかった。深達度別では, 平 均浸閏距離は s m $6.9 \mathrm{~mm}, \mathrm{~m} \mathrm{p} 10.1 \mathrm{~mm}, \mathrm{~s} \mathrm{~s} 18.9 \mathrm{~mm}$, $\mathrm{s}$ e $34.8 \mathrm{~mm}, s$ i $21.5 \mathrm{~mm}$ てあり, $21 \mathrm{~mm}$ 以上の浸閏例 は全例 s s 以深てあった. 食道浸閏形式との関係ては 粘膜型（浸阔が粘膜層のみ），限局浸阔型，びまん浸 淍型，脈管型(癌浸阔の先端部が脈管侵震になってい るもの)の平均食道浸閏距離は，それそれ $5.5 \mathrm{~mm}, 15.3$ $\mathrm{mm}, 29.2 \mathrm{~mm}, 58 \mathrm{~mm}$ てあり，粘膜型ては $15 \mathrm{~mm}$ 以上の浸閏 例は認められなかった。食道浸閏距離の判定誤差は， 粘膜型ては10mmの1例を除いた7例が，限局漫閏型ては 32 例全例が $5 \mathrm{~mm}$ 以下てあった。これに対しびまん浸閏 型ては10例中4例に, 脈管型ては4例中2例に $10 \mathrm{~mm}$ 以上 の判定誤差が認められた.

\section{示-12精神分裂病患者における胃癌手術例の検討}

東京都立松沢病院外科

木田孝志, 羽生 丕, 片桐 一, 川端啓介

【目的】精神分裂病は䍜病期間が長く, 患者は長期 間にわたり向精神薬を投与されている。この間に消化 器癌を合併するととも少なくない。今回われわれは精 神分裂病患者の胃癌を対象として, 臨床病理学的特徴 の有無を検討した。

【方法】1989年から1994年までの 5 年間に, 胃癌で 当科に入院し手術を受けた精神分裂病患者17例を対象 とした。全国胃癌登録調査報告の昭和63年度症例を対 照として比較を行った。分類用語は胃癌取扱い規約 （第11版）に従った。

【成績】対象17例の平均年齢は59.1 歳で, 男性10例, 女性 7 例, 精神分裂病の羅病期間は平均 27.3 年であっ た。切除16例 (治癒 12 , 非治痹 4 ), 単開腹 1 例で, 癌の占居部位, 組織型, 転移 ( P.H.N)等対照群との 間に有意差を認めなかった。 $\mathrm{S}_{3}$ が 6 例 ( $\left.35.3 \%\right)$ ， Stage Nが 7 例 ( $41.2 \%$ )を占め, 対照群（それぞれ $14.99 \%, 18.3 \%)$ に比べ多かった $(p<0.05)$ 。

【結論】精神分裂病患者に発見された胃癌は, S因 子, Stageの進だ例が多いものの, 一般の胃癌に比べ 大きな差異は認みられなかった。 
示-13 Zollinger-Ellison 症候群の経遇中、残胃に発 生した多発性カストリノーマの 1 例

西宮市立中央病院外科、同病理 ${ }^{11}$

三木宏文、柴田信博、相川隆夫、山本秀薣、

中野克俊、野口貝夫、玉井正光 ${ }^{1)}$

近年 $\mathrm{A}$ 型胃炎に続発する高カスストリン血症による胃

カルチノイト腫富発生の報告例が增えているが、最も 典型的な高カススリン血症を呈するZollinger-Ellison 症 候群と胃カルチノイド重席との合併は極めて稀である。 今回我々はZollinger-Ellison 症候群の長期経遇中に残胃 に多発性ガストリノーマを生じた症例を経鈋した。

高カストリン血症に繶発して胃に発生するカルチノ イト腫褯はnon-functional tumor であり、functional tumor (カスストリノーマ) が多発した報告はなく、新発生し たものか、胃壁内枟移であるのかという点で興味ある 症例である。
示-15胃軸捻転が食道裂孔に㛶頓し、汎発性腹

膜炎を起こした一例

東京都済生会中央病院外科

松井哲、今津嘉宏、中田宗彦、茂木克彦、奈良貞博、 大山廉平、石飛幸三

胃軸捻転症は発生頻度が0.05\%という比較的稀な 疾患である。今回、成人胃軸捻転症が、食道裂孔ヘル ニア顸頓を起こした手術例を経倹したので、若干の文 献的考察を加えて報告する。

【症例】69藏男性医師、1994年1月28日より呕吐、 腹痛、下利にて発症した。2月1日になり、哐吐・腹 痛が增悪したため緊急入院となった。来院時、腹部は 板状硬で沉発性腹腽炎の状態であった。

【手術】2月1日、緊急開腹術を施行した。閉腹所見 は食物残渣を含む大量の腹水が眝留し、大網及び胃幽 門側が小鹙線を軸にして180度捻転し、食道裂孔に骀 頓していた。胃は胃角部から幽門前庭部にかけて、大 鸺側が広範な壊死状態にあった。塿死部を切除するよ うに、広範囲胃切除・B I 再建術を行った。術後、滕 頭部の仮性動脈瘤を生たが、再手術で事なきを得た。 【考察】本症例は、大網が先進部となり、胃の大签側 までがparaesophagial tapeのヘルニアとなっていた。

食道裂孔ヘルニアの合併症として重篤な内ヘルニア の欮頓を起こすを危険性を念頭におくべきである。

示-16高度食道浸洞を伴う進行胃瘦に対して 術前術後のintensive chemotherapyが有効であっ た一例

荅龍会 井上病院 ${ }^{1 ）}$ ，大阪大学腫瘍外科 2 )

阪本 康夫 ${ }^{1}$ ），藤田昌英 ${ }^{1}$ ，楠山剛紹1），山田 周立 ${ }^{2}$ ，高井 新一郎 2 )

[症例］52歳女性、食道に $6 \mathrm{~cm} に$ 及ぶ浸潤を伴い、噴 門部より胃角に及ふ $12 \mathrm{~cm}$ 径の巨大なボールマン2型の 胃癌を認めた。術前化学療法として、CDDP $70 \mathrm{mg} /$ body， $5 \mathrm{FU} 250 \mathrm{mg} /$ body $\times 3$ 日間の亜選択動注の後、全身投与 にてCDDP $140 \mathrm{mg} /$ body $5 \mathrm{FU} 500 \mathrm{mg} /$ body $\times 5$ 日間を2ク ール行った。その結果、腫瘍は著明に縮小し、胃及び 食道の壁伸展性もほとんど正常となり、bPR と判断さ れた。化学療法終了後28日目に、左開胸開腹下に下部 食道切除、胃全摘術の根治術が可能であった。病理学 的には、Po Ho mp noly3 vo stage Ibであった。化学療 法前に病変が存在した部位では筋層の断裂・消失や線 維化巣及び黄色肉芽腫での置換を認めた。術後経過良 好で、術後44日目、89日目に同化学療法を2クール施 行した。 [結語] 高度進行胃癌に対してCDDPと $5 \mathrm{FL}$ の併用療法を術前3クール、術後2 クール施行し、2年6 カ月間無再発で経過している症例を得、術前後の intensive chemotherapyの意義が檄めて高かったと考え られたので報告する 
示-17 low dose CDDP, 5FUによる胃癌術前化学 療法の検討 一組織学的効果およびTSIRについて一

千葉大学第一外科鈴木弘文, 布村正夫, 滝口伸浩, 幸田圭史，小田健司，早田浩明，寺戸孝之, 尾崎和義, 知久毅, 近藤英介, 若月一雄, 斎藤典男, 更科広美, 中島伸之【はじめに】胃癌症例に対して, down staging を目的として low dase CDDPを併用するフ卟コールを実施し ている。今回, 病理組織学的効果およびThymidylate Synthetase Inhibition Rate(TSIR)について評価検討し た。【対象と方法】進行胃癌と診断された 24 例 (男:女二 19:5, 平均年秢61.2)を対象とした。生検組織型は高分化 型(tub1, tub2, pap)11例, 低分化型 (por, sig, muc)13例で

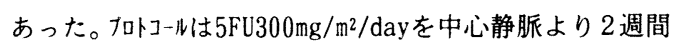
以上(平均 17.8 日) 持続静注し, CDDP $15 \mathrm{mg} / \mathrm{m}^{2} / \mathrm{day} 5 \mathrm{FU}$ 開 始日から 2 日間静注した。胃癌取扱い規約に従い効果判定 し, また切除標本より21例にTSIR值を計算した。【結果】 病理組織学的効果は, Grade 0-4例, Grade 1a-13例, Grade 1b-1例, Grade 2-5例, Grade 3-1例であり, Grade la以上は 83. 3\%, Grade 1b, 2, 3は, 29.2\%の効果を認めた。以下組織 学的効果との関連を検討すると, 生検組織型では有意差を 認めないか，壁深達度との関係では $\mathrm{t}_{1}$ 症例の効果が高く $(\mathrm{p}<0.01), 5 \mathrm{FU}$ 総投与量は多い程効果が高かった $(\mathrm{p}<0.05)$ 。 また, TSIR値はGrade 1b以上が有意に高値であった $(p<$ $0.05)$ 【結語】今後更に症例を重ね検討してゆきたい。

示-18UFTを用いた手術待機期間中の胃癌の Neoadjuvant chemotherapy 島根医科大学第一外科

佐藤仁俊、仁尾義則、矢野誠司、長見晴彦、 金 聲根、瀬下達之、角 昭一郎、田村勝洋 (目的)我々は,胃癌の手術待機期間中にUFT経口投与によ るmildな術前化学療法を行っており，現在32例に達し，そ の効果と有用性を検討した.(対象と方法)UFT投与量(日) は,300-600mgで,投与期間は7-36日(平均18.3).効果は胃癌 取扱い規約に基つきき判定したが, 手術が前提のため,肉眼 的効果は奏効期間を考虑せず,腫瘍縮小効果のみで判定 した.また投与後の血清及び組織中薬剂濃度も測定した. (結果)26例で投与前後の画像を比較でき,胃病変ではCR が2例,PRが8例,NCが16例であった(奏効率38.5\%). 病理学 的効果は,grade2が32例中6例にみられた.いずれも投与量 が多く,投与期間が長い程有効であった. 組織内薬剂濃度 (mg/g tissue)は17例で測定でき,FT,5-FUの平均は2.445, 0.054. 副作用は消化器症状が主で, 術後合併症は繾合不全 が2例,穿孔性MRSA腸炎が1例みられたが,投与量過多が 原因之考えられ,体重の少ない例や副作用出現例では, 長 期投与により術後合併症の発生する可能性がある. 予後 ついては,32例中P3の2例とn4の1例か，それぞれ12,6,21力月 で,残胃再発胃癌の1例が16力月で死亡している.(結論) UFTによる胃癌の術前化学療法は,簡便で副作用が少な く,外来通院で投与可能である点, 静注化学療法より優れ, 奏効率も高いところから, 手術待機期間中の癌の進行予 防のみならず,Down-stagingを計りうることが示唆された.

\section{示-19 Stage $\mathbb{1}$ 進行月癌, 再発㾔に対する} MTX/5F U交代療法の治療成䋶

富士宮市立病院外科

大久保忠俊, 梅原靖彦, 長渡裕子, 土屋泰夫, 中村利夫, 坂元隆一, 佐野佳彦, 森山龍太郎

[目的 ]Stage N 進行胃癌および再発胃癌に対してMTX ／5F U交代療法を施行し，その治療成績を報告した。 [対象と方法]対象はStage N進行胃癌（進行群） 23 例と再発胃癌(再発群) 15 例である。方法はMTX 100 $\mathrm{mg} / \mathrm{m}^{2} \mathrm{c}$ 静注, 1 時間後飞 5 FU 600mg $/ m^{2}$ を静注, MTX 投与 終了 24 時間後から leucovor in $15 \mathrm{mg}$ を 6 時間ごとに 4 回 投与した。外来患者はMTX 40〜 $50 \mathrm{mg} / \mathrm{m}^{2}, 5 \mathrm{FU} 500 \mathrm{mg} / \mathrm{m}^{2}$ とした。以上を 1 サイクルとして毎週繰り返した。な お開腹した症例は CDDP 50〜 100mg 腹腔内散布した。 [結果]進行群完全例 20 例の奏効率は30\%, 再発群完 全例12例の奏効率は15\%であった。進行群の60\%に CEA , CA19-9 オすれれかの改善を認めた。進行群の1 年 生存率は $28.1 \%$ で, 50 \% 生存期間は 10.5 ケであった が, 奏効例のみでは26ケ月と有意に良好であった。再 発群の50\%生存期間は 8 力月で, 1 年生存率は $28.1 \%$ であった。副作用は高率にみられたが，汪とんどが Grade 2 以下であり, 重篤なるのは認められなかった。 [結論] MTX/5F U 交代療法は, Stage $N$ 進行胃癌に対 して試みる価値のある治療法であると思われた。

示 -20 腹腔細胞診

東京都立大久保病院外科 ${ }^{1)}$, 病理科 ${ }^{2)}$

丸山道生 ${ }^{1)}$, 江淵正和, 菅野範英, 高松督, 片田雅 孝, 小林利子, 滝沢登一郎 ${ }^{2}$ )

(目的) 我々は消化器䂏の再発もしくは再発予防に 腹腔ポートをもちい腹腔内化学療法を入院, 外来で長 期施行している。腹腔ポートを用い, 腹水の認められ ない例でも細胞診が可能である，化学療法による腹腔 内癌細胞の变化を経時的に観察した。（対象）腹腔内 細胞診陽性胃癌 8 例, 膵癌 1 例, 食道癌 1 例の計 10 例で ある.（方法）1）腹腔内化学療法 1-2週ごと MTX-CDDP-5FU, MTX-5FUを生食1000-1500mlに 溶解し腹腔ポートより注入. 腹水例では適宜生食制限. 投与期間は1-9月, 平均 3.5月 2) 細胞診 定期的に 腹腔ポートより腹腔内液を $5 \mathrm{ml}$ 採取. 腹水(-)例では腹

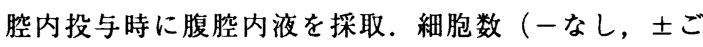
く少数, +少数, ++多数) および癌細胞の変性の程 度（D0変性なし, D1軽度変性, D2高度変性）を観察.

(結果) 腹水 $(+)$ 例では治療にともない細胞数 ++ から $\pm に$, 癌細胞変性はD0からD2へ2月で変化. 腹水(-) 例では細胞数は+で約 1 月で細胞数は+から士, 変性 はD0，D1からD2に変化. 腹腔ポートを利用した腹腔 内液細胞診は化学療法の効果のfollowに有用であった。 
示-21胃内多発癌の臨床病理学的特徴と外

科治療上の問題点

国立病院九州がんセンター消化器部外科

馬場秀夫、大城辰雄、足立英輔、鴻江俊治、松岡秀夫 瀬尾洋介、斎藤貴生、友田博次

【目的】胃内多発癌の臨床病理学的特徵を明らかにし 外科治療上の問題点と対策について検討した。

【方法・結果】当院で切除された胃癌2500例を対象 とした。1）多発癌は157例(6.3\%), 326病変であり、 80 歳以上では $21.8 \%$ と高齢者に多かった。早期病変 のみは74例、進行癌を含むものが81例であり、2病 変が154例、5病変が3例であった。2）多発癌では単 発癌に比べ年㱓が高く、男性の割合が多く、分化型癌 の割合が高かった。早期多発癌では隆起型の割合が多 く、進行多発癌ではBorrmann I,II型が多かった。3） 多発癌症例中、胃部分切除術後の残胃再発率は $1.5 \%$ で あり、単発胃癌と差はなかった。4）多発瘦157例中 重複癌は17例(10.8\%)であり、単発癌の7.3\%に比し重 複癌合併頻度が高かった。5）多発癌、単発癌治瘾切 除例について予後を比較したところ、5生率は各々 65.9\%、70.7\%で有意差は認められなかった。

【まとめ】胃内多発癌に対しては術前の十分な検索に よる適切な術式の決定と切除胃の詳細な組織学的検討 が必要と考えられた。

\section{示-22当院における多発胃虹の臨床病理学的検討}

一外科的立場から-

\section{太田西ノ内病院 外科}

馬場裕之、山崎 若山 宏、高橋正泰、

三浦則正

[目的] 多発胃疾は術前に指摘されるようになった か、術後の病理組織学的梌索により指摘される場合も 数多い。外科的治療上問題点か残されている。

[対象と方法] 1990年から1994年6月までの4年6r 月に切除された胃疾602例を検討し、病理組絤学的に 多発胃疾の32例を対象とした。年柃、性別、占拠部位、 大きさ、肉眼型、組織型、深達度、リンパ節転移、術 前䛦断を比較検討した。

[成結] 多発胃癌の比梨5.3\%で、平均年柃69.5嵅、

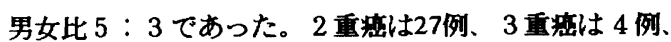
4 重教は 1 例認めた。肉眼型ではさIIを主体とする陥凹 型が33病変、隆起型は19病変であった。組䋘学的に分 化型が62病変、未分化型 8 病変であった。発生部位は A、M領域に多く、C 領域は 6 病変のみであった。術 前見落としは 7 病変にのほった。

[結論] 高糩者男性で萎縮性変化が強い症例では多 発胃恣の頻度が高い。紡小手術が選択され残胃が大き い今日、胃疾は多発することを念頭に術前検査を十分 に行わなくてはいけない。

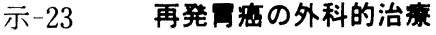

岐皁市民病院外科

大下裕夫, 田中千凯, 種村廣已

【はじめに】再発胃癌に対する治療は可能な限り再切除 することが望ましいが，切除率は低く，再手術後の生存期 間も短い，今回，われわ机は根治手術が行われた胃癌症例 のうちで，過去10年間に再発入院した76例を対象に，再発 胃癌の特徵と再発例に対する有効な外科的治療について の検討を行った。【結果】初回手術から再発までの平均 期間は22.3力月であった. 再発形式は腹膜42例（51.9\%）, 局所 23 例 $(28.4 \%)$, 肝転移 7 例 $(8.6 \%)$ ，全身転移 5 例 (6.2\%)，残胃 4 例 (4.9\%) であった. 40 例（52.6\%）に 延べ45回の再手術が行われた。再発形式別の再手術率は腹 膜26例 $(61.9 \%)$, 局所11例 $(47.8 \%)$, 残胃 4 例 $(100 \%)$, 肝転移 4 例（57.1\%）であった。再手術術式は腸錬のみ 16 例, 腫瑒切除 7 例, バイパス 7 例, 肝切除 4 例, 残胃全摘 4 例などであった. 再発病巣を切除しえた症例（治窟切除 例）は8 例で, 肝転移 4 例, 残胃再発 3 例, 局所再発 1 例 であった. 再発からの平均生存期間は外科的治療例13.9力 月，非外科的治療例7.6力月，全体10.9力月であった．外科 的治療例の再手術からの平均生存期間は 11.2 力 月であるが, 非治瘾例の 4.7 月に対して治瘾切除例は 37.4 力月と良好 であった。【結語】肝転移や残胃再発例では腹膜再発や 局所再発例と比へてて治痹切除となる可能性が高く，再手術 後の生存期間の延長も十分期待できる.

\section{示-24進行胃痘治瘾切除症例の再発形式、時期} の検討

国立病院九州がんセンター消化器部外科

白水章夫、長嶺信治、宮崎信彦、大城辰雄、

足立英輔、馬場秀夫、鸿江俊治、松岡秀夫、

瀬尾洋介、斎藤貴生、友田博次

【目的】進行胃癌治瘾切除症例について臨床病理学的 因子の解析を施行し、再発形式、再発時期の検討を行 い、再発のhigh risk症例の特徽を明らかにした。

【対象と方法】1972年4月から1992年1月までに当科 にて治瘾切除が施行された進行胃癌915例のうち、不 明 115 例(12.6\%)除く再発例250例(27.3\%)、非再発例 550 例(60.1\%)を対象とし検討を行った。

【結果】(1)再発形式の内訳は、腹膜播種135例(54.5\%)、

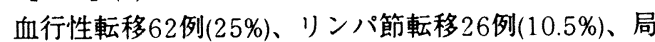

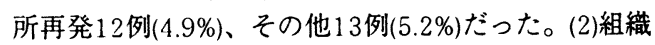
型では腹膜播種が未分化型(76.7\%)に、血行性転移が 分化型(60.7\%)に多かった。(3)再発時期では3年以内の 早期再発例が195例(82.9\%)と大部分を占めていた。

【結語】進行胃癌症例では、たと之治瘡切除がなされ ても、その臨床病理学的因子をふまえた術後のfollow upが必要であり、また、術後 3 年以内に腹膜播種や肝 転移による再発が多いため、再発のhigh risk症例に対 しては術後钽重なfollow upが必要と考えられた。 
示 -25

田要術後の晩期再発例の模剖

一特に早期再発例との比䩙を中心に一

自简像中央病院外科

伊英人 長谷和生野辟一 小川也

宇部宫勝之村山道典小林秀粑 山田省一

渡逢千之石山资

【目的】今回我々は，田虫の晩期再発と早期再発を臨

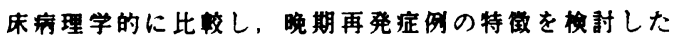

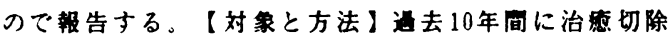
後再発をした44例を対象にし，術後30か月以内に再発 した34例を早期再発群，31か月以上柽透して再発した

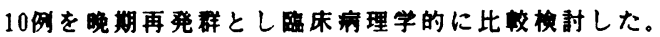

【蛣果】1)再発時期は，平均57か月で長 72 かであ った。2）再発形式は，局所再発 $(50 x)$ 腹㬺再発 $(40$ x）がはとんどで，局所再発では垡胃再発了㽝，枟移り 八・節牫存による大渴狭空を2例認めた。3）臨床病理学 的な特徽は，全例男性で，肉眼型は限局型，占居部位

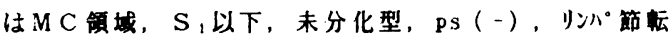
移は四性でも1群以下，师節䖝移個数 4個以下が多か ラた。4)手術は全例部分切除例であり，占居部位（M C）のため追加切除やtonyをおいた症例があった。

【桔語】1，晚期再発の场合，追加切除やtｏmyによる手 術の䒬の癌のimplantationや，部分切除から生じる枟 移リンパ節の残存("10,11)により時期が星れて局所に 再発した可能性があると思われた。

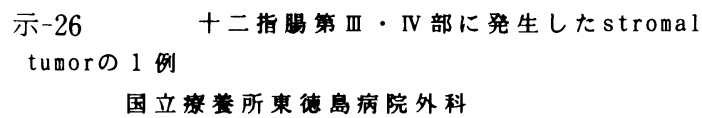

福本泰三，田中克浩，先山正二，六田媈朗

十二指渴原発腫癌の頪度は低く，上皮性腫㾺と非上

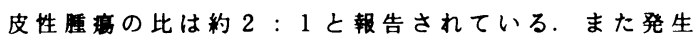
部位は第I 部から肛門側に向かって頻度が低くなると

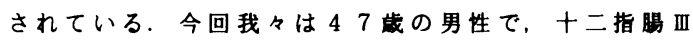

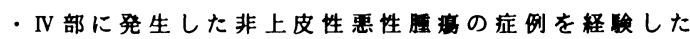
ので報告する

全身倦急感，めまいを主訴に来院。血液検査にて高 度の低色素性實血を琵めた。低䋈張性十二指晹造影に て, 十二指晹水平部・上行部の上方に約 $3 \mathrm{~cm}$ 大の除影

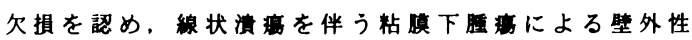
の压迫所見を梕めた。腹部 C T, 超音波桧査では，上

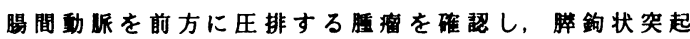
との境界は不明瞕で一部浸间を疑った，以上ょり十二

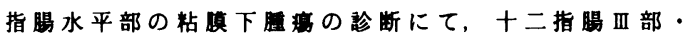
$\mathrm{IV}$ 部と上部空腸切除を施行した。また勝鈎状突起の一

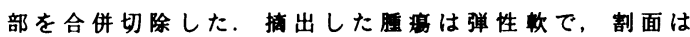
黄色湖で光沢を有し，中央部に壤死紧を認め, 十二指 腸内㓐に瘦孔を形成していた。組織学的にはspindle

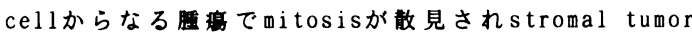
of duodenum, lov grade malignantと參断された.

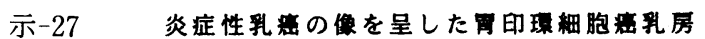
枟移の一甽

掼浜市立大学医学部第一外科学教室

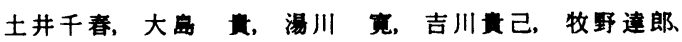
野口芳一，天野畐签，松本昭彦

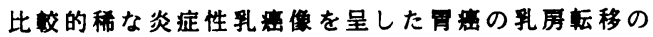

一例を報告する。

症例は 51 歳女性。主訴は左拜房の発赤腷脹。平成6 年

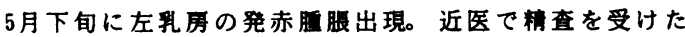

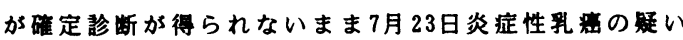
で当科を稆介受診した。外来で精查を進めたが、全身

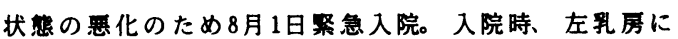

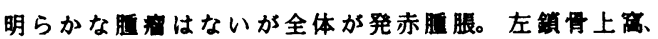
左渡密に大豆大のリンパ節を脶知。腹部所見上、心空

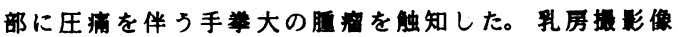
で左秏房の皮度の著明な肥原、航腺除影の增強を認め た。上部消化管造影で月体中下部に著明な等硬化、伸

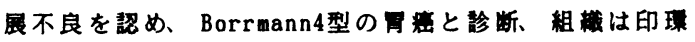

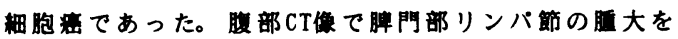

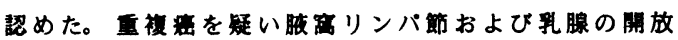

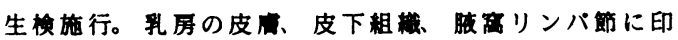

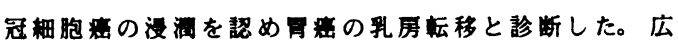

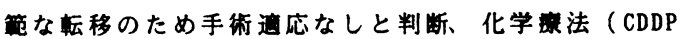
, 5-FU）を施行、現在左乳房の発赤腰脤は怪快している。

示-28早期胃瘦2病变と胃原発性覀性リンパ

缰の共存した 1 例 浜松赤十字病院外科、藤田保健衛生大学病理 ${ }^{*}$ 河野光智、奥田康一、久 晃生、西脇 畺、 保田健太郎、曽我良平、住山正男、堀部良宗*

癌腫と覀性リンパ腫とが同一胃内に共存する例はま れで本邦報告例は約60例である。われわれは Borrmann 2 型様の胃原発性覀性リンパ腫と IIC+III 型及び IIc 型早 期胃癌の3病変が併存した1例を経験したので報告する。

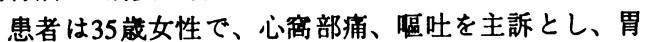
内視鏡検査にて胃体中部後壁に Borrmann 2 型病変、胃 体下部前壁に IIc+III 型病変、胃体下部後壁に IIc 型病 変を認め、生検病理検査で前者からは低分化型腺癌、 後者2病変からは低分化型腺癌と印環細胞癌が検出され た。3重複胃㿋の診断のもと幽門側胃切除術を施行した。

切除標本の病理検査結果は、Borrmann 2 型病変は悪 性リンパ腫, diffuse, inter 〜 large cell type、IIc+III 型病 変と IIc 型病変は印環細胞癌であった。他病変、転移は 認めなかった。術後経過は概ね良好で現在外来にて経 過観察中である。

胃悪性リンパ腫と癌腫の鑑別は容易ではなく、其存 例で術前に両者ともに診断されている例は少なく、本 症例も術前に悪性リンパ腫の診断は得られなかった。 以上、症例を若干の文献的考察を加え報告する。 
示-29蛋白漏出性胃腸症の発症を契機として発 見された I 型早期胃癌症例 査部 ${ }^{2)}$

健康保険岡谷塩嶺病院外科 ${ }^{1)}$, 信州大学中央検

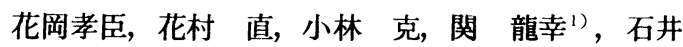
恵子, 勝山 努 ${ }^{2)}$

蛋白漏出性胃腸症の発症を契機として発見された非 常に稀な I 型早期胃癌の 1 治験例を報告する。

[症例] 70 歳女性。高血圧症・脳梗塞後遺症にて 経過観察中、利尿剂投与にても持続する四肢の著明な 浮腫と黒色便を主訴に入院した。 入院時, 高度の低蛋 白血症 ( T. P. 4.4 g/d l ), 低アルブミン血症 ( A 1 b 2. $7 \mathrm{~g} / \mathrm{d} 1$ ) および貧血 ( RBC $295 \times 10^{4} / \mathrm{mm}^{3}$ $\mathrm{Hb} 8.4 \mathrm{~g} / \mathrm{d} \mathrm{l}$ ) を認めた。上部消化管内視鏡検査で は，胃前庭部後壁に隆起性病変を認め，生検の結果， 高分化型管状腺癌であり，I 型早期胃癌と診断した。 アルブミン製剤投与と輸血にて低蛋白血症と負血の改 善をはかった後，幽門側胃切除術を施行した。第17病 日には，T.P. $6.6 \mathrm{~g} / \mathrm{d} 1 ， \mathrm{Al} \mathrm{b} 3.5 \mathrm{~g} / \mathrm{dl}$ と著明 に改善し，第37病日軽快退院した。

[考察]病理組織検査から，本症例では，癌主病巣 からの蛋白漏出というょりも，むしろとれに随伴する 癌周井移行带の過形成性粘膜の透過性九進により, 多 量の血桨蛋白の漏出が引き起こされたと考えられた。

\section{示-30枟移性胃裙についての湌討 東京都立的込病院外科}

山本哲久, 北村正次, 荒井邦佳, 岩崎善数, 稻田一爑, 谷口忠明

転移性胃索は非常にまれな疾患であり、その多 くは剖湌時などに倜然発見されることが多い。今

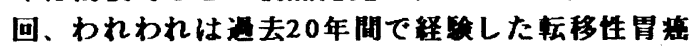

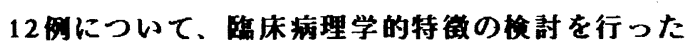

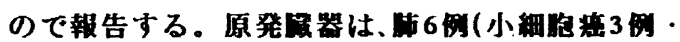

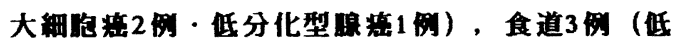

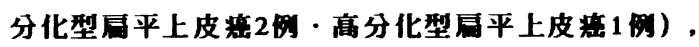

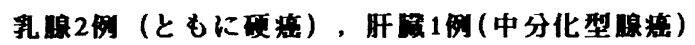

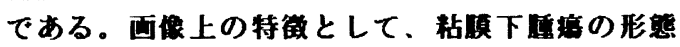
をとることが多く、最大径も $3 \mathrm{~cm}$ 以下が7何 $(58$ \%)であった。病聁の占居部位はM領域が6场 (50\%) て、C，A領域にみられたのは各々3仿

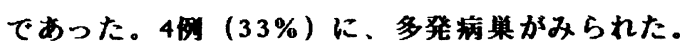

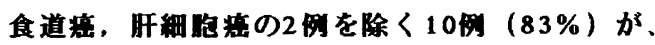

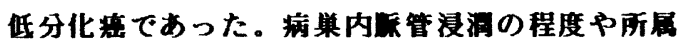
リンバ節転移，他目器血行性転移の有等より捈郡 すると、9份 (85\%) については血行性轱移が考

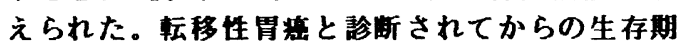
間は、1力月から德長28力月 (平圴11力月) であ り、予後は不良であった。

\section{示-31転移性胃腫瘦の 4 例}

千葉県がんンタ- 消化器外科

辛太廣、本田一郎、藤田昌宏、渡辺一男、渡辺敏、 山本宏、山田滋、山本尚人、神宮和彦、古谷成慈 くはじめに>癌腫の転移部位として胃は稀な䑏器であ る。4例の転移性胃腫瘍を経験したので報告する。 <対象>肺癌 2 例、乳癌 2 例で肺癌例は非切除、乳癌例 は胃切除が行われている。

一結果>肺癌例は共に胃癌の診断にて来院している。両 者とも胃全域に多発する小さな 2 型病変を有し、生検に て未分化癌（小細胞癌？）の診断を得て胸部 X-Pを施 行したところ䳕卵大と手拳大の腫瘤陰影を各々認め、気 管支鏡による生検で小細胞癌が確認された。しかし、診 断時点で他臓器にも転移が見られ 2 例ともに 3 力月後に 死亡した。乳癌例は胃転移の診断の 3 年、9 年前に乳癌 の手術を受けており、肺転移、骨転移を何九も胃切除 前に有し、1 例は肺部分切除を受けており、胃切除後 3 年 10 力月生存中である。もう 1 例は胃穿孔で緊急手術、 2 個の転移巣を認めたが増覀した肺転移のため胃切除後 10 力月で死亡した。

人結語>癌腫の転移部位としては稀な転移性胃腫瘍 4 例 を経験したので報告する。

\section{示-32消化管平滑筋肉腄症例の検言 仙台赤十等病院外科 \\ 中川国利、佐藤 俊、臼井律郎、豊島 隆、}

桃野哲、佐々木陽平

消化管平滑筋肉腄手術例を臨休病理学的に検討し、

若干の知見を得たので報告する。

，対象了過去 11 年 8 月間に手術を行った消化管平滑

筋肉腫 15 例 (胃 10 例小腸 5 例) を対象とした。

| 結果、男女比は $8: 7$ 、平均年齢は 61.3藏であった。 胃での発生部位は噴門部が多く、小腸では全例が空腸 に存在した。術前に平滑筋肉腫と診断しえたのは㠵の

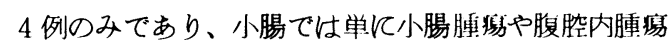
としか診断でをなかった。手術は、直接浸膶していた 蔵器を含めて積極的に切除したが、組織学的にリンパ 節転移を認めた例はなかった。なお他缄器浸閏を認め た例は管外型や管内外型で、強倍率で平均核分裂数が 5 以上の 4 例ではんずれる朋転移を来たした。死亡例 は 6 例で、いずれも最大腄第径が $6 \mathrm{~cm}$ 以上と大をく、 管外型や管内外型であった。再発巣に対しても積極的 に再手術を行い、予後の改善を認めた。

（結語了消化管平滑筋肉腫の術前診断は困難であり、 管外型や管内外型、椫控径か $6 \mathrm{~cm}$ 以上、核分裂数が 5 以上の例では予後が不良であった。しかし、積極的 に切除することにより、予後の改善が期街できた。 


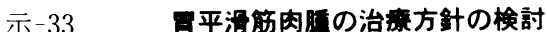

\section{平塚市民病院外科}

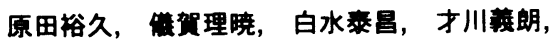
石田秀檄，会沢健一郎，小野崇典，金井被雄， 石川度記

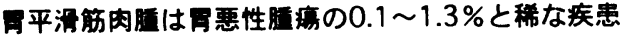
である。今回我々は当施設において1989年10月から 1994年9月までに切除を行った需平滑筋肉腷8例を対 象として模討し、治㫫方針について若干の知見を得た ので報告する。

[結果および考睻] 男性2例女性6例で、平均62.6 端であった。術式は、用全摘・脾合併切除3例、幽門 侧切除2例、部分切除3例であった。胉瘄最大径は平 均 $8.3 \mathrm{~cm}$ で、周囲学器への直接浸洞やリンパ節坛移は 1例も现めなかった。1例において、術前より肝枟移 $\left(\mathrm{H}_{2}\right)$ を眼めた。再発死亡例は1例のみで、術後2年目 のCTにて肝枟移 $\left(\mathrm{H}_{1}\right)$ か発見された後、3度にわたる TAEにて2年4ケ月生存しえた例である。他の6例は

再発なく生存中である。以上の結果より、本疾患に おける術式は、可能な限り司部分切除が妥当であり、 巨大な置曒に対しては術中の肝動脈へのカニュレーショ ンの有効性が示唆される。また、術後の肝枟移に対し てはTAEを䅡極的に施行することにより、生存期間の 延長がはかれるものと思われた。

示-34胃平滑筋肉腫に対する局所切除術の適応 国立がんセンタ一中央病院外科 ${ }^{11}$, 同研究 所病理 21 , 久留米大学内科 ${ }^{31}$

片井均 ${ }^{11}$, 笹子三津留 ${ }^{11}$, 佐野 武 ${ }^{1}$, 岡島一雄 ${ }^{1)}$, 丸山圭一 ${ }^{11}$, 落合淳志 ${ }^{21}$, 古賀浩徳 ${ }^{3}$

[目的]胃平滑筋肉腫は比教的稀な疾患でその治療 方針については、わが国でもいまだ合意が得られてい ない。当院では本腫度（特に小腫苦）のリンパ節転移 頻度が極めて低いことより1982年以来 $5 \mathrm{~cm}$ 末満の腫䫓 に対して局所切除を中心とした治療を行なっている。 今回はその成績から適応の是非を検討した。【対象と 方法了1972年1月から1994年6月までの初発胃平滑筇肉 腫 92 例の臨床・病理学的所見, 再発形式, 生存率を検討 した。[成繶] C領域が腫癌の好発部位で59例，以領域2 4 例，A領域 9 例であった。術式の内訳は核出術 1 例, 局所 切除 60 例，胃切除 31 例であった。系統的リンパ節郭清 が行われた22例でリンパ節転移を認めた症例はなく、 転移を認めたのは姑息手術中に迅速診断で確認した 1 例（腫湶径 $15 \mathrm{~cm}$ )のみであった。予後追跡中の死亡は 10 例、うち腫死は8例であった。局所再発は核出術の 行われた1例のみでリンパ節再発はいずれの術式でも 認めなかった。 5 年生存率は全例で $85.6 \%$, 局所切除 89.8\%，胃切除 95.8Xであった。

[結論] 当院での局所切除の適応は妥当と思われた。
示-35術前画像診断にて胃壁内外混合発育型の

胃平滑筋肉腫と診断された胃悪性神経鞘腫の 1 症例 益子病院胃腸科 ${ }^{\nu}$ 、東京慈恵会医科大学病理 ${ }^{2)}$ 、

同第 2 外科 ${ }^{3)}$

二村浩史 ${ }^{1)}$ 、池上雅博 ${ }^{2}$ 、佐藤慶一、二階堂 孝、 上符正志 ${ }^{1}$ 、益子 博、佐野芳史 ${ }^{3)}$ 、高山澄夫、 青木照明

胃原発の悪性神経鞘腫は極めて稀な疾患である。今 回我々は、術前画像診断にて胃壁内外混合発育型の平 滑筋肉腫と診断された胃悪性神経鞘腫を経騃したので、 若干の文献的考察を加えて報告する。症例は、46 歳、 男性。検診の上部消化管 X線にて胃角から幽門にかけ て $5 \mathrm{~cm}$ 大の粘膜下腫瘍を認めたため、精査入院となっ た。腫湯マーカーを含めて血液検査は正常であった。 腹部超音波にて胃に辺縁不整で内部.コ一不均一な低. コ一域を認めた。胃カメラにて胃角に中心潰瘍を形成した 隆起性の粘膜下腫瘍老認めた。上腹部CTにて胃の内外 突出した腫瘤を認めた。転移は認めなかった。てれらより、 混合発育型胃平滑筋肉腫亡診断し、幽門側広範鬲切除術 $D_{1}$ 郭清)を施行した。肉眼では、 $84 \times 43 \times 33 \mathrm{~mm}$ の胃壁内外に 突出した腫瘤で、割面は白色の充実型腫瘍であった。組織学 的に怯、紡鏵型細胞力不規則な交錯をし核のWaving,Palisading、 周辺リンパ球漫潤さらと核分裂像も認めた。NSE,S-100陽性、 Desmin, $\alpha$-SMA陰性であり、胃覀性神経鞘腫と診断された。

示-36 肺瘭を合併したCarney症候群の 1 症例 日本医科大学第一病院外科 ${ }^{\prime \prime}$, 同消化器病センタ-21

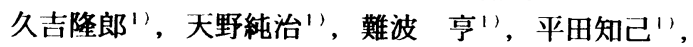
栗原雄司 ${ }^{1}$, , 赤若 順 ${ }^{21}$, 田崎達也 ${ }^{21}$, 的場康德 ${ }^{2}$

[症例] 72才男性。主訴：咳。家族歴と既往歴に悪性 疾患なし。胃平滑筋肉腫：昭和58年 7月胃内視鏡で弓 隆部および体上部に隆起吽病変を発見された。同特期 に左卜肺野の円形陰影を指摘されたが良性病変と診断。 開腹手術ではC 領域後壁, 大弯側に鶏卵大で表面やや 不整の腫留があり, 周囲との瘉着やリンパ節の腫脹は なく, 噴門部切除十空腸間置術を施行した。摘出標本 では $4 \times 3 \mathrm{~cm}$ の腫煌が胃壁外性に約 $4 \mathrm{~cm}$ 発育していた。 病理組織検查では噴門部の腫瘍は類円型の核を有した 紡鍾状の細胞からなる充実性腫瘍でleiomyosarcoma 診断した。体上部の小腫溜はleiomyoma であった。 睍病歴 : 平成 5年10月再診時の胸部 X線写真で右上葉 の無気肺がみられ, 気管支鏡検査では気管分岐部から 右主気管支の狭控部があり, 生検では高分化型扁平上 皮癌であった。肺血管造影では右肺動脈幹の閉寨像が みられ, 術前化学燎法後に右肺sleeve pneumonectomy を行った結果, t4n0m0であった。術後 6 ヶ月に癌死, 剖検により左肺結節病変は軟骨成分に富むhamartoma と判明。本症例は本邦 3 例目のCarney症候群であり, 肺癌と合併した報告は文献上見いだせなかった。 


\section{示-37 小細胞疾と腺癌が同一病集内に共存した \\ 早期再癌の1例}

福井総合病院外科

藤田 隆、伊藤 雅之、北村 秀夫

胃原発の小細胞癌の1切除例を経験したので報告する。 症例は、72才の男性。平成6年6月胃集団検診で異常 を指摘され、胃内視鏡を施行し幽門部大弯にIIa+IIcの腫 瘍を認めた。入院時血液生化学データーに異常值はな く、既往歴として陳旧性肺結核があったが、胸部X線写 真及び胸部 C T 上、肺原発の腫瘍を疑わせる所見はな かった。7月29日 胃严全摘術(R2 郭清, B-2法再建)を施 行し、手術時診断はA, Maj, IIa+IIc, $3.5 \times 2.0 \mathrm{~cm}, \mathrm{~N}_{1}(+)$, $\mathrm{P}_{0}, \mathrm{H}_{0}, \mathrm{~S}_{0}$ であった。組織学的には、腫瘍の中心部に 円形又は楕円形の核を有する未分化な小型細胞がびまん 性に増殖し、一部に索状配列や偽口ゼット構造が認めら れたことから小細胞癌と考えられた。組織診断は、sm, $\mathrm{Ly}_{1}, \mathrm{v}_{0}, \mathrm{INF} \alpha$, ow $(-)$, aw $(-), \mathrm{n}_{1}(+)\left[\mathrm{n}_{1} 4 / 24, \mathrm{n}_{2} 0 / 8\right.$ で あった。また中心部小細胞癌の周囲には、中分化型の腺 癌の共存が認められ、腺癌部は深達度 $\mathrm{m} 、 1 \mathrm{y}_{0} 、 \mathrm{v}_{0}$ で あった。小細胞癌部は、グリメリウス染色陽性、クロモ グラニン染色陽性、サイトケラチン(CAM 5.2)染色陽性 で、腺癌部は、これらの染色は陰性であった。

手術後3週目よりCDDPとVP-16を用いた化学療法を 施行し、現在のところ再発の兆候なく経過良好である。

\section{示-38胃原発扁平上皮癌の 1 例}

梅原病院外科 ${ }^{1}$, 日本医科大学第一外科 ${ }^{2)}$

渡辺 章 ${ }^{1}$ ，梅原松水 ${ }^{1}$ ，梅原松臣 ${ }^{21}$, 堀場光二 ${ }^{21}$, 笹島耕二2'，山下精彦 ${ }^{2)}$, 恩田昌彦 ${ }^{21}$

胃原発の扁平上皮癌は極めて稀で本邦報告例は10数 例を数えるに過ぎない。その組織発生については腺癌 が扁平上皮化生したとする説が比較的諸家に支持され ているが未だ定説はない。最近, 我々は胃原発扁平上 皮癌の 1 切除例を経験したので若干の文献的考察を加 え報告したい。

症例は62歳の男性。上腹部重圧感, 下血を主訴とし て近医で胃潰瘍と診断されたが, 貧血が強く入院治療 のため平成 6 年 3 月 30 日に入院した。入院時胃内視鏡 検査では胃体上部，小彎側に深い潰瘍を認めた。4月 27日の再検査時には病変部の辺縁にビラン, 発赤を認 めたので生検をおこなったところ結果はGroup V ，扁 平上皮癌が疑われた。5月14日に胃全摘出術および脺 体尾部, 脾を合併切除した。切除標本では食道胃接合 部より約 $1 \mathrm{~cm} の$ 胃体上部, 小彎側にBorrmann 2 型の腫 瘍を認めた。病理組織では角化傾向を伴い大小の充実 性胞巣を形成して増殖する扁平上皮癌で腺癌成分の混 在は認めなかった。また, 食道粘膜との連続性はなく 食道断端にも癌は認めなかった。術後経過は良好で術 後32日目に退院した。

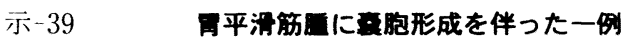 佐贺罢立病院好生馆外科、同放射稳科 ${ }^{11}$ 同病理模查科 ${ }^{2)}$}

沖英次、渡辺昭博、岡 直威、吉田朗

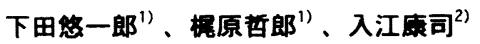

われわれは、萛胞形成をきたし、診断が因素であっ た平滥筋浐の症例を経験したので報告する。

【症例】69被、女性。因透裸、内视鏡では、胃体上

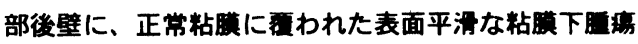

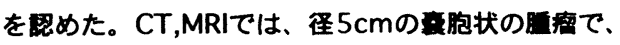
血管造野ではvascularityはあまり睌められなかった。 以上より、平滑筋肉目あるいはduplicationを考え、

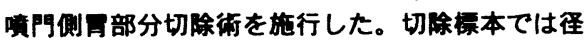

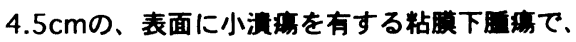
割面では小泣胞の形成を多数思めた。病理学的には、 leiomyomaと診断された。梱胞間は浮腷状で索胞を

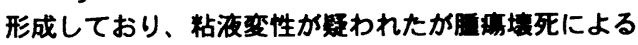
可能性もあると考えられた。覀性所見は既められなかっ た。【結語】的床的にきわめてまれな、胞を形成し

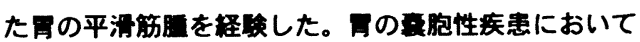

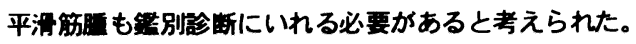

示-40再発のみられた胃原発悪性顆粒細胞腫の 1 例

国立金沢病院外科、研究検査科 *)、放射線科 **)

松本尚、小島端彦、竹川茂、井上哲也、木下睦 之、津田宏信、渡辺騏七郎*)、小林昭彦**)

【臨床释過】症例は64藏、女性。腫疾は胃内視鏡上、 粘膜下腫场の形態を示し、Echo、CTでは肝左葉に接し て径 $6 \mathrm{~cm}$ と $5 \mathrm{~cm}$ のダルマ状の腫㾇を認め、契音波内視鏡

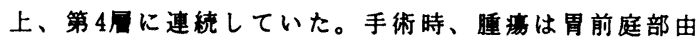
来で幽門側胃切除術を施行した。病理組維所見では、 細胞は超大型の充実性腫施で、豊富な顆粒状の淡好酸 性胞体と大型の異型核を有し、核分裂像もよく認めら れ、悪性の顆粒細胞腫と診断された。しかし臨床所見 上は他䐬器浸潤、リンバ節転移などはみられず、悪性 と判断するには疑問が残されていた。【退院後経過】 初回手術から1年9力月後に右上腹部に腫箩を触知、CT

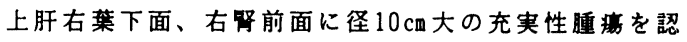
めた。【手術所見】腫㑥は横行結腸間膜内に位置し被 膜に包まれており、結腸を含め周辺筥器への浸润はみ られず、横行結晹切除術を行った。【病理組䋨所見】 組織学的には腫湯細胞は初回手術の所見と同様であっ た。【考察】顆粒細胞腫は一般に良性腫饬とされる稀 な疾患であるが、本症例では胃原発の顆粒細胞腫で、 臨床的、組織学的に悪性と孝えられた。 
済生会山形済生病院外科”, 㸪形大学医学部 第2病理 ${ }^{2}$ ，大泉胃腸科内科クリ二ック”，

太田圭治，吾妻正章，瀨尾伸犬'，川监和彦”， 大泉晴史

胃カルチノイドは, 全胃悪性腫瘍の().1\%と稀であ るが, 曽我らの報告によると，消化管カルチノイド 中，直腸に次いで多く，約3割を占める。

胃カルチノイドは, 腺萵に存在する銀親和性細胞 が発生母地と考えられており，上皮性腫場であるが， 粘膜下に容易に浸潤し，粘膜下腫瘍状の形態を呈す ることが多い。

背景として，高ガストリン血症，及び萎縮性胃炎 の存在が報告されており，幽門洞部を切除された残 胃は発生母地に成り難いと考えられる。

今回我々は，出血性胃潰瘍にて幽門側胃切除術を 施行され，30年目に残胃にカルチノイドが発生した1 例を経験したので，若干の考察を加えて報告する。

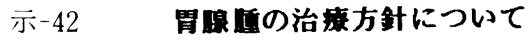

大阪医科大学一般 - 消化器外科

$\begin{array}{lll}\text { 泉 信行, 岡島邦雄, } & \text { 磯崎博司, } \\ \text { 中田英二, } & \text { 一八名正, } & \text { 仁木正己, } \\ \text { 奥田準二, 野村栄治, } & \text { 藤井敬三, }\end{array}$

[目的] 近年, 内視鏡下甾粘膜切除術 (以下, E M R) の普及により胃腺腫の治療にも変選かみられるように なった。今回, 教室で経験した胃腺腫の腺腫内蛅合併 率およびE M Rの治療成績から胃腺腫の治療方針を検 討した。[万法] 遇去10年間について経験した胃腺腫

(腺腫内疾を含む) 47例49病変について，その腫㢈死 径と腺腫内密合併事を検討するとともに，胃等を含め たEM Rの切除率についても榙討を加えた。

[成績] 腺腫内站は長径 $20 \mathrm{~mm}$ 以上の腺腫では 9例中5 例(56\%)に，10〜19mmの腺腫では25例中9例(36\%)に認 めた。また手技的にEMRにて確実に単回切除できる のは, 大きさ別には $20 \mathrm{~mm}$ 末淗の病変であるが, 占居部 位別には胃体部, 前庭部の前後壁の完全切除率は低率 である。[結論] $10 \mathrm{~mm}$ 以上の胃腺腫は腺腫内窟合併率 が高く皘極的な切除が必要と考えられた。切除法は10 〜19mmの腺腫には E M Rを，20mm以上の腺腫には胃 局所切除が妥当であり,またEM Rに際してはその占 居部位を考虑して慎重に適応を決める必要があると考 える。
示-43胃縮小切除術式の厂大

公泣学校共済組合近畿中央病院 外科

青木太郎、西哃清訓、宮开博志、請井敏定、 上村佳央、宮内啓輔、寺島 毅、金子 正、 水谷澄夫、阙川 和弘

【日的】胃切除術後には種々の愁訴が起こるが、こ れを子防し患者のQOLを改善するため縮小切除を試み てきた。今回これらの症例について検討した。

【方法】最近の6年間に縮小切除を施行した14例を 対象とした。術式別にみると輪状切除 3 例、楔状切除7 例、局所切除5例となっている。これらの症例に対し 術後の消化器生理機能を術後愁訴、UGI、GIFの所見 をもとにして評価した。

【結果】いずれの症例においても術後の愁訴は軽度 で常食への復䡅も早い。ダンピング症候群、逆流性食 道炎の発生もみられていないし、食事摄取量も術前と 大差ない。UGIにても造影剂の通過は良好で乎術によ る胃変形の影響はあまりない。GIFにても著変は認め られていない。

【考察】縮小切除といっても部位によって上述の如 き術式の亡大が必要であり、今後さらに検討を続けた w。

示 -44 胃全摘後空腸pouch再建の有用性に関す

る検討

天保山記念病院外科

奥村 浩、喜入 厚、上門千哲、前之原茂穂、 1993年1月より1994年7月までに施行した胃全摘25 例を I . 従来のRoux-Y群 $(\mathrm{n}=11)$, II . 空腸pouch作成 群 $(\mathrm{n}=5)$, III. 空腸pouch作成及び腸瘦併設群 $(\mathrm{n}=9)$ の3群に分け、術後の栄養状態の指標として血夜学的 検討、体重増加率、食事摄取状況、術後愁訴に関し て3群間の比較を行った。その結果、血夜学的には各 群間に有意差を認めなかったか、、体重増加率で四群 は他の 2 群と比較すると体重減少の割合が少なかった 。食事摄取状況では各週における全量摄取が可能で あった患者の割合は I 群64、82、82\%、II 群60、100 100、III群56、67、78、であった。術後愁訴はダンピ ング症状は I 群で18\%、II 群では認められず群で $11 \%$ あっった。逆流性食道炎はそれぞれ27、20、11 $\%$ 、腹満は55、40、33\%、吐気・煰吐は36、20、44 \%に認められた。以上より腸㿉併設した空腸 pouch作 成群は食事摂取量は不十分ながら体重減少の割合が 少なく術後の栄養改善に有用でありまた、空腸pouch 作成群は術後早期に食事摂取量の増加を期待でき,さ らに術後愁訴の軽減をはかり、QOLの向上に寄与でき うると思われる。 
示-45 胃切除後のバルトラック使用経験

旭川市 唐沢病院 唐沢洋一, 小嶋信博、工藤浩市

目的 : 胃の広範切除後と胃全摘後空腸間置後の胃十二 指腸球部、空腸十二指腸球部端々吻合、 B - II 法胃空 腸端側吻合に使用した経験を得たので報告する。 はじめに : 生体内分解性消化管吻合器 (VA L T RA C）は1981年よりアメリカンサイアナミッド社とトー マス・G・ハーディ医師との共同開発として始まった 。日本では小西、桝井らによる大腸の吻合が多数行わ れ、安全性が確認され、94年 4 月 4日より保険適用と なり使用が可能となった。

対象と方法 : 1994年平成 6 年 3 月 22 日から胃広範切除 3 例、胃全摘後空腸間置術 3 例、胃覀全摘術 1 例に使 用した。この内、胃全摘空腸十二指腸球部吻合部に小 吻合不全が 2 週間後に発生したが、開腹せず経過観察 した。B－II法の胃空腸吻合部のガストログラフィン の通過が10日までが通過不良であり、13日から流動食 を始める。

結論 : 大腸の吻合には適するが、胃腸吻合には利点も 多いが、一考を要する。

示 -46 自動吻合器を用いた胃十二指腸吻合術

の検討

\section{日生病院外科}

吉川幸伸, 宗田濼夫, 森匡, 奥野慎一郎, 中島清一, 栗原陽次郎

[目的・対象]幽門側胃切除術にて切除可能な胃悪性 腫瘍を対象とし, 自動吻合器を用いた胃十二指晹吻 合術を施行し，その有用性を検討した．[方法]十二 指腸を切離し, circular staplerのanvilを十二指腸断 端に巾着縫合する.予定切離線を定め,これより肛 㑡前壁にて胃切開し，病巣部を肉眼的に確認する。 切開部より circular staplerのshaftを㨉入し, 残胃後 壁と十二指腸を端側吻合する．粘膜面から直視下に 吻合部を観察する.ついでlinear staplerを用いて幽 門側胃切除を施行する. [結果]1991年6月から1994 年8月まで86例の胃悪性腫湯に対し，本法を施行し た。術中に胃十二指腸吻合部の i n c o m plete doughnut4例, 動脈性出血3例を認め, 追加䋖合を施 行したが,これらの症例に術後合併症は認めなかっ た．術後合併症としては䋖合不全 1 例，吻合部㹨窄 1 例を認めた。[まとめ]本法は腫場の浸潤籁囲，口㑡 断端への浸閵の有無, 吻合部を肉眼的に確認でき, しかも簡便な術式である。また術後合併症は少なく ，遠隔成績も十分満足しうる術式と考えられた。
示-47器械吻合を用いたBill roth I 法およびBi

11 roth II 法再建術

南ヶ医病院外科 ${ }^{2}$ 、全沈大学第一外科”

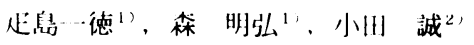

【月的】半成 5 年10月よりBill roth I法およびBill roth II 法在器械吻命で行い、手術特間の短縮に努めた。 【対象之 j法】11Billroth I 法（7例）：E E Aの分 解アンビルを十二指晹断端に㨉人した。划除予定の胃 の前壁大敖側に小切開を加え、E E A の本体を挿入し、 後壁大管側に罱十二指腸吻合を作成した。次にT A 90 を用い、盟幽門側を横断吻合そして切離切除した （哭械２碑）(2)Bill roth II 法（3例）：T A - 55 で ト二指腸断端を吻合閉銷した，トライッより約10〜15 $\mathrm{cm}$ 空腸に小切開を加え、E E Aの分解アンビルを㨉 人した、次に(1で述べた方法で、胃空晹吻合を作成し、 さらに T A - 90を朋い、製を切除した。（器械 3 個） 【成績と結論】10例全例、手縫い法の䫉より手術時間 が短縮され、䋖合不全や吻合部狭窄などの合併聇は認 められなかった、リンバ節郭清などの嵒の根治術操作 に全精力を注ぐことができるようになり、矤撩コスト の面加らも経済的であった。また吻合技術に差がない 利点も持ち命わせており、この们用な吻命法をより適 比に心用すべきと觉えられた。

\section{示-48胃悪性リンパ腫に対する治療方針 岡山済生会総合病院 外科}

戸田耕太郎，広瀬周平，筒井信正，大原利憲，木村 秀幸, 三村哲重, 岡本康久, 赤在義浩, 玉木孝彦, 竹 内義明, 大塚真哉, 児玉雅治, 松村年久, 片岡和男

（目的）胃悪性リンパ腫手術例の予後を検討し, 進 行度に応じた治療方針を決定する。（対象と方 法）1965年から1993年までに 当科で経験した 胃悪 性リンパ腫手術例37例のうち, 胃癌合併例 1 例, 盲 腸癌合併例 1 例および直死 2 例を除く，33例を対象 とした。うちわけは, 切除術単独例 7 例, 切除術十術 後化療例24例, 術前化療 +切除術例 1 例, 非切除例 1例で，それぞれの予後を検討した。

その結果，次の結論を得た。(1)根治度（胃癌取扱い 規䄪）は胃悪性リンパ腫の予後を良く反映した。(2)根 治度 $A$ 症例では切除術のみで良好な予後が期待できる。 (3)根治度 $\mathrm{B}$ 症例のうち, noないしn1(+)にとどまるも のに対しては, 術後化療の付加が適応である。(4)根治 度 $\mathrm{B}$ 症例のうち, $\mathrm{n}_{2}(+)$ 以上之根治度 $\mathrm{C}$ 症例では切除 術+術後化療の治療成績は全く不良であった。従って, 術前検查で明らかに, $\mathrm{N}_{2}(+)$ 以上ないし, 根治切除不 能（根治度C）之診断された症例に対しては, 術前化 療が適応であり，長期生存も期待できると考える。 
娌医協中央病院外科

河島秀昭, 石後网正弘, 皇山広已, 山崎左雪, 細川誉至雄, 平尾雅紀

[対象および方法]1976年6月より1994年3月まで に当院において手術を受けた再要性リンパ通は 21 例 で、そのうち深逢 s m 77 例を対象とした。性別は、

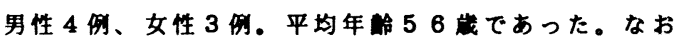
生存曲線は、Kaplan-Meier法にて算出した。

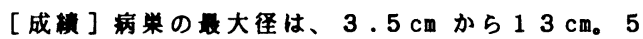
$\mathrm{cm}$ 以下の症例か3何にみられた。肉眼型は、表首拡大

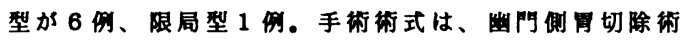

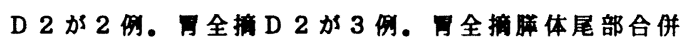
切除 D 3 を 2 例。術得の化学综法は、3例に施行され た。病理組織学的検查結果で、リンパ節枟移はn 1 か

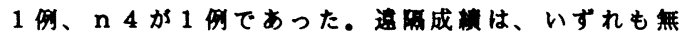
再発生存中であり、5年生存率は $100 \%$ あった。

[考案]肉眼型の多くは表四拡大型で、浸洞籍囲か 術前に碓定できない症儌もあり、全揞術が必要と考 えられた。リンパ節部清の程度はD 2 が妥当と考えら れた。化学㾣法に良く反応すると考元られ、予後は良 好で㤓尾部啸合併切除は行わす、リンパ節枟移淂性 例に対して術後の化学恶法を付加するべをと考える。

示 -50 胃悪性リンパ腫手術例の予後因子に関す る検討

大阪厚生年金病院外科、“同病理検査科 李 千万、山崎芳郎、愁田圭司、大野喜代志、 橋本純平、山崎 元、山本重孝、西田幸弘、坂口太一、 *小林 曼、“小武内優

過去 14 年間に経験した胃原発覀性リンパ腫手術施行 27 例の予後を DNA Ploidy Pattern を含む各種臨床病理 学的要因について検討した。DNA 量測定はつローサ仆外 リーにより解析を行った。性別, 年榆は、男性 13 例 (57.1土14.1葴)，女性 14 例 (62.6土6.2墄)で生存率 に有意差を認めなかった。治療は、幽門側胃切除 5 例， 胃全摘 22 例 (脾，膵体尾部，腸管合併切除 9 例を含む) で手術根治度において有意差を認めた。術後補助療法 は化学療法のみで、21 例で静注施行しており、その 有無により有意差を認めなかった。胃癌取り扱い規約 上の深達度, リンパ節転移の有無については、生存率 に有意差を認めなかったが、Ann Arbor 分類,Naqvi 分 類で有意差を認めた。核 DNA 量では diploid 例が良好 な傾向にあり、根治度 Bでも術後 139 ヶ月の長期生 存を認めたが、根治度 A,aneuploid 例では早期肺転移 死亡例を認めた。まとめ)各種要因の中では、根治度， リンパ節転移，他膈器浸潤が予後に関与しており、核 DNA 量は、生物学的悪性度を反映していた。
示-51早期胃悪性リンパ腫症例に対する化学療法 の効果についての検討

大阪府立病院消化器一般外科 ${ }^{1)}$, 同消化器内科 ${ }^{2)}$ 、 同病理科 ${ }^{3)}$ 、大阪警察病院外科 ${ }^{4)}$ 、市立芦屋病院外科 ${ }^{5)}$ 田中康博 ${ }^{1)}$ 、高尾哲人 ${ }^{1)}$ 、渡辺洋敏 ${ }^{1}{ }^{2}$ 、城戸哲夫 ${ }^{11}$ 、 宮本 岳 $^{2)}$ 、井上善文 ${ }^{1)}$ 、砂田祥司 ${ }^{1)}$ 、虎頭 廉 $^{3)}$ 、 仲原正明 ${ }^{4)}$ 、中尾量保 ${ }^{4)}$ 、佐谷 稔 ${ }^{5)}$ 、志水洋二2 ${ }^{21}$

【目的】胃悪性リンパ腫に対する治療は、一般に、手術 療法が第一選択とされる。今回、手術に先行して化学療 法を施行した早期胃墨性リンパ腫症例において、切除標 本を病理組織学的に詳細に検討しその成績について報告 する。【対象】1990-94年6月に手術を施行した早期胃覀 性リンパ腫症例10例を対象とした。病期(Ann Arbor分類) はIE7例、IIE3例。年路40-65歳、男4例、女6例。組織型 (LSG分類)はdiffuse, medium sized cell type 7例、diffuse, small 2例、diffuse, large 1例である。【治療・成績】手術 に先行してVEPA2クールの化学療法を施行した。化学療法 終了後、第2群までのリンパ節郭清を伴う幽門側胃切除 術または胃全摘術兼膵体尾部脾荗合併切除を施行した。 病理組織学的にIEの2例において切除胃の粘膜下小範囲 に腫瘍細胞の残存を認めた。しかし、他の8例において は切除標本に腫瘍細胞の残存を認めなかった。

【結語】早期胃悪性リンパ腫に対して、化学療法を第一 選択とし、全胃を温存し得る可能性が考えられる。

示-52胃悪性リンパ腫 5 例の検討一現在の治療 方針にもとついた最近の症例の検討

浜松医科大学大 2 外科

丸尾祐司、今野弘之、金井俊和、松田絾、

田中達郎、西野惕彦、馬敬正三

平成 4 年 4 月以降当科において 5 例（男 3 例、女 2 例、51〜75歳、平均61.2歳）の進行胃悪性リンパ腫に 対し現在のわれわれの治療方針にもとついて治療を行 い良好な成結をおさめたので報告する。

組織型は L S G 分類で、びまん性大細胞型 4 例（こ のうち 1 例にびまん性小細胞型の胃悪性リンバ腫を合 併）、びまん性中細胞型 1 例であった。4 例に胃全摘 術、1 例に胃亜全摘術を行い、うち 3 例に D 2 以上の リンバ節廓清を行った。胃癌取り扱い規約による分類 では、stage II 1 例、stage III a 1 例、stage IIIb 1 例、stage IVb 2 例であり、総合的根治度では、根治 度A 1 例、B 2 例、C 2 例であった。術後 4 例に化学 療法を行い、うち 2 例に CAMB0-VIP療法を、2 例に Weekly-CHOP 療法を行った。根治度 Cとなった 2 例に おいては化学療法後残存腫瘍は消失し、また現在まで に全例とも再発なく生存中である。 


\section{示-53 小渴平滑筋肉腫と肺癌の同時性重複曹 \\ 性腫㴼の1例}

国立大竹病院外科

古川雅文、星野修司、長尾由尚、片山繁、小野栄治

【㫌例】58歳、男性。平成5年11月頃から咳濑あり、胸部 X線にて、右中肺野に異常陰影を認め、入院となる。 【人院後経過】超音波下経皮針生検にて、肺腺癌との診 断があり、平成6年2月7日、右肺葉切除を施行した。術 後第15病 日、消化管穿孔による汎発性腹膜炎にて緊急 手術となった。開腹にて、トライツ勒带から約 $30 \mathrm{~cm}$ 䏠 門側の空腸に管内、管外性に発亩する充字性腫痹を認 め、約 $30 \mathrm{~cm}$ 空腸を切除した。病理学的には、非常に 悪性度の高い低分化な平滑筋肉腫と診断された。病理 組織学的に、肺腺㾔組織には、肉腫様变化があり、光 初、肺癌からの転移が疑われたが、免疫組織学的検查 により肺と小腸の重複悪性腫啺と診断された。

【考察】小晹平滑筋肉腫の悪性度の評価としては、腫瘍 径、核分裂像の数が予後を反映する重要な因子である が、本症例においても、最大腫㾖経 $8 \mathrm{~cm} 、$ 核分裂像 10 個/10視野と高い悪性度を示し、早期に遠隔転移を来た し急速な臨床経過をたどったものと思われる。また、 免疫組織学的検查により、小腸平滑筋肉腫が、肺癌の 肉腫様変化を来たした部位からの転移ではなく、冬々 独泣した悪性腫瘍であるということが判明した。

\section{示-54胃と多荗器重複癌症例の検討} 福井医科大学第 2 外科

下松谷匠、谷川允彦、青竹利治、天谷博一、松村光誉 司、藤井秀則、増田靖彦、村岡隆介

当科で経験した胃癌手術例之多葴器の重複癌症例につ いて検討した。【対象】1984年より施行された胃癌手術 例は387例であり、重複癌は23例(5.9\%)に認められ、3重 複癌は1例のみで、同時性14例、異時性9例であった。性 別では男性18例、女性5例であった。平均年齢は同時性 72. 1歳、異時性64. 2歳で全体の63.8歳に比べ高かった。 他臓器癌の内訳は、肺癌と大腸癌が多かった。前期( 1989年) と後期 (1990年-)で検討すると、前期9例 (4. 2\%) に対し後期 14 例 $(8.0 \%)$ と有意に増加し $(\mathrm{p}<0.01)$ 、特に 肺癌が増加していた。【治療】8例で同一入院で両臓器 の癌の切除手術が行われたが、大腸癌 5 例と食道癌 1 例は 一期的手術が行われ、肺癌の2例は二期的に行われた。 手術は胃全摘4例、幽切15例、噴切2例、局所切除2例で あった。郭清は1群以下が8例、2群以上が15例であっ た。【成績】進行度は I aが13例と多く、根治度はAが 15例と多かった。早期病変は15例 $(65.2 \%)$ と多かった。 組軄型は17例(73.9\%)が分化型であった。生存率は胃癌 之他臓器の癌の一方あるいは両方が進行している例が不 良で、予後は両者の進行度に影響されており、それに応 じた治療内容を選択すべきと考えられた。
示-55一期的に切除し得た消化管原発の同時性三 重複悪性腫演の一例

足利赤十字病院外科

小柳和夫、藤崎真人、長谷川博俊、平畑 忍、

前田大、小島由光、阿部仁郎、松本昌久

同時性に発見した胃癌、盲晹癌、胃原発平滑筋肉腫 を一期的に切除し得た症例を経䀫したので文献的考察 を加えて報告する。症例は54歳男性で、食欲不振を 主訴に近医を受診し、便潜血陽性を指摘された。大晹 ファイバーで 1 型の盲腸癌を認め、胃十二指腸ファイ バーでは胃体上部から幽門輪にかけ3型の胃癌を認め た。また大弯側よりの圧排所見を認めた。腹部 C Tで は、胃大弯側に約 $12 \mathrm{~cm}$ 大の腫瘤を認め、巨大なリン パ節転移と診断した。胃癌と盲晹癌の重複癌と診断し、 7 月 8 日手術を施行した。胃㿋は墏膜面に露出してお り（SE）、横行結腸間膜に腹膜播腫（P 1) (+) を認 めた。術前、リンパ節転移と思われた胃大弯側の巨大 な腫瘤は、胃体部より連続しており胃原発の肉腫と診 断し消化管原発の三重複悪性腫富の術中診断であった。 胃全摘術、腹膜播腫転移栄切除術、回盲部切除術およ び胆震摘出術を施行した。病理組織学的所見：胃は中 分化型䋐毛腺癌で、盲腸は、中分化型腺癌、肉腫は胃 原発平滑筋肉腫であった。経過順調にて、術後補助化 学療法を1クール施行後、退院した。

示-56濃厚な癌家族歴を持つ三重複窝の 1 切除例 東邦病院 ${ }^{1)}$, 群馬大学第 2 外科 ${ }^{21}$, 最上胃晹科外科 ${ }^{31}$ 荒井清充 ${ }^{11}$, 大和田進 ${ }^{21}$, 森島榐 ${ }^{11}$, 高橋仁 ${ }^{11}$, 荻野隆史 ${ }^{21}$, 小川哲史 ${ }^{21}$, 中村正治 ${ }^{2)}$, 泉勝 ${ }^{21}$, 最上建治 ${ }^{3)}$, 森下靖雄 ${ }^{21}$

今回，濃厚な祦家族歴を有し結晹，胃，肝に発生し た三重複癌手術症例を経験したので報告する.

症例は70才男性. 家族歴で父は胃癌で, 母は脺搭癌 で, 姉は胆衰癌で, 妹は大腸癌・卵巣癌で, 弟は大腸 癌でいずれも死亡している．また既往歴では，1992年 12月にS状結腸癌(mod.diff. adenoca.) でS状結腸切除 術を受けた。1993年3月初旬，発熱を主訴に来院した。 腹部超音波検査で肝左葉外側区域に低エコ一性の腫瘤 と肝内胆管の拡張を, また上腹部CT検查では肝左葉外 側区域に周囲が造影剂で增強される等吸収域を認めた. 腫癔マーカーはAFPか2.8ng/mlと正常であったが, CEA は13.8ng/ml, CA19-9は995.1U/mlと高値であった. HBs $\mathrm{Ag}, \mathrm{HCVAb}$ は陰性であった，以上より転移性肝腫㙞又 は胆管細胞癌を疑った。さらに上部消化管内視鏡検査 で胃体上部大弯側後壁に3型の腫㾇がみられ, 生検は Group V，卵環細胞癌であった。1993年5月胃全摘，肝 左葉切除術を施行した. 病理組織学的に胃癌はmucinous adenoca.であり, 肝腫瘍はadenosquamous ca.で あった。術後約 $2 力 月$ 目に残存肝多発転移で死亡した。 
示-57 消化管癌、特にMuir-Torre症候群に

おけるgenetic instability

名古屋大学第 2 外科

日比健志、伊藤浩明、仲田和彦、近藤建、秋山清次、 伊藤勝基、高木弘

[目的]最近種々の㿋においてreplication error(RER) が報告されてきている。我々は消化管嘴およびMuirTorre症候群についてこうしたgenetic instabilityを調 ベたので報告する。［方法］消化管癌症例114例から DNAを抽出し、これを Templateに3種類の microsatellite markerを用いてPCR を行い、その産物 を denaturing polyacrylamide gel に流すことによって、 正常組織と癌組織とで移動度の違いを調べる。[結論] HNPCC familyに頻度の高い胃癌、大腸癌では、それ ぞれ29例中3例 $(10 \%) 、 72$ 例中11例(15\%)において RERが認められたが、頻度の低い食道癌では13例中 0 例（0\%）とRERを認めず、同じ消化管においても遺 伝的な病因は単一でないことが明らかとなった。また Muir-Torre症候群の症例においては9個の癌について genetic instabilityを調べたが、全ての癌において3種 類の microsatellite markerのうち少なくとも1つにRER が認められた。このことから考えてMuir-Torre症候群 の中にはHNPCCと同様にDNA repair geneに異常が生 じてRERを起こすものがあると考えられた。

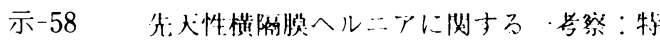

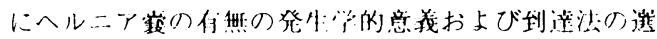
扒に一いて

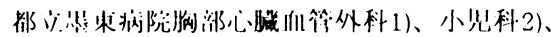

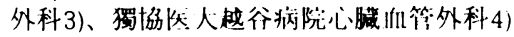

禹雅祥1）、佐野英基1）、田辺貞雄1）、松永裕司 1 )、

関一郎 2) 、福留厚3)、山目崇之4)

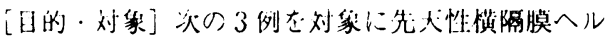
ニアの到達法の選択とヘルニ学の有無の意我に一い

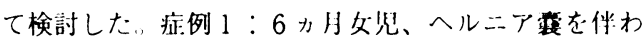
ず、ヘルニア門後縁横隔膜の久損したた:Bochdalek孔 ヘルニアをト腹部横切開で厅術した。为: 例 $2 ： 74$ 诚

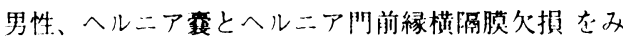

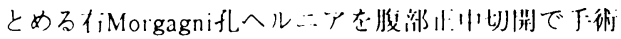

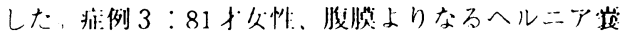

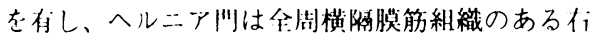
Morgagni孔ヘルニアを㺃骨正中切開で手術した。

[考察・結枋] ヘルニア囊の有無、ヘルニア門の横 陑膜筋成分の伯血は：pleuroperitoneal hiatusが筋成分 やpleuroperitoneal membraneにより閉鎖される時期と の関係で説明される。横隔膜へルニアの構成成分でへ ルニア衰を有し、ヘルニア門に横隔膜筋組織の欠落の ない高龆者では後天的荘因の関与が疑われる(症例 3 )。

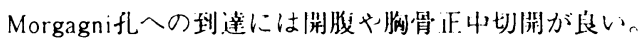

\section{示-59的鎖孔ヘルニア12例の検討 長猗步立島原温泉病院外科}

山口聡, 大久保仁, 石井辰洋, 松尾繁年, 籍崎卓雄 [目的］成制孔へルニアは診断側の認識の欠如により 術前診断か困難なことか多い. 我々は12例の閉鎖孔へ ルニア症例について筤床的に検討したので報告する.

[方法] 1984年6月から1994年4月までに12例の閉鎖 孔ヘルニアを経験し，瞖床的な検討を行なった.

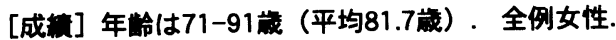
分婏回数1-8回（平均5.1回）。体重は31-45kg（平均 $36 \mathrm{~kg}$ ） ，症状はほとんどかイレウス症状でHowship-R omberg徽候（以下HR徽候）は12例中9例（75\%）に みられた，術前診断での正診率は58\%（12例中7例） だった．当科に紹介される前の段陼での正診率は8.3\% （12例中1例）で9例中8例にH R 微候の認識かなされて いなかった. 最近の2例はCTで診断した. 病依期间は 3-22日 (平均8.8日) だった. 左右差は右側9例, 左側

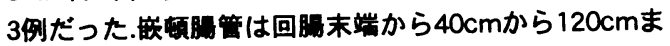
での部位にあった. 腸切除を要したものは9例であった. ヘルニア門は全例結節䍩合のみ行なった. 術後合併症

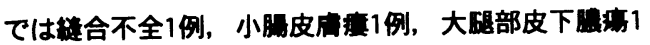
例であった. 手術死亡例はなく，再発も認めていない.

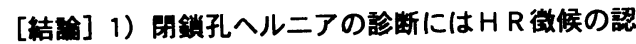
酸が要である．2）C Tは磪定診断に有用であった.

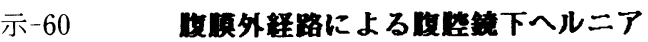

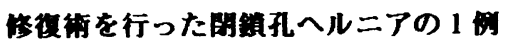 赠科赤十字病院外科}

横山隆秀, 宗像康博, 上島哲哉, 荻原迪唐

我々は，術前嗐断できた非嵌頓性の閉鎖孔へルニア に対し，腹嘋鏡下にヘルニア修復術を行い得た 1 例を 経験したので報告する。

[症例] 84嵗の女性で，体重32kg と廈せており，2年前 から右大腿部内侧部にへルニアの脱出を自觉していた。 ヘルニア涚出時に腹部不快感と右下肢のしびれを感じ ていたが，自分で䅉刺していた。これらの症状から右 明鎖孔ヘルニアと診断し，予定手術を行った。

[万法] 呼吸機能の高度の障害を慧めたため，碩䐜外 麻醉下に腹䐜外経路で复巆鏡下へルニア修復術を行っ

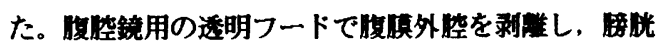

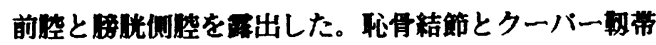

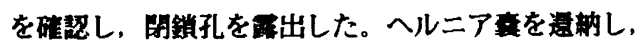
ポリフロヒレンメッシュを当て，手術を終了した。

[結果] 的鎖神経の損伤なく，術後7日目退院した。

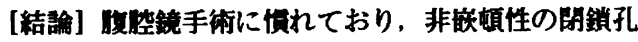
ヘルニアを術前影断できれは，腹傎外経路による腹脴 鏡下ヘルニア修得術は有効な方法と思われた。 
示-61 腹腔鏡下鼠径ヘルニア修復術における prolene meshと周囲組織との結合力に関する研究

帝京大学溝口病院外科、臨床病理科*

加納宣康、春日井 尚、阿部宏之、石山純司、山川 達郎、水口國雄*

[目的]著者らは腹腔鏡下鼠径ヘルニア修復術施行時、 inguinal floorの補強にポリプロピレン製材である prolene meshを使用している。そこで今回、メッシュ が周囲組織と安定した固定状態を形成するのに必要な 時間を確定するため以下の実験を行った。

[方法]ラットをエーテル麻酔下に開腹、鼠径部およ び腹直筋部で腹膜を切開し、鶃径部では大腿動静脈が 露出する層で、腹直筋部では腹直筋や腹斜筋群が露出 する層で約 $2 \times 2 \mathrm{~cm}$ の範囲を剥離、 $1 \times 1 \mathrm{~cm}$ 大のprolene mesh片を剥離面に置き、ヘルニアステイプラーで固定 し、切開した腹膜は繾合閉鎖した。このようにメッシ ユを植え込んだラットを術後第 1 、第 3 、第 5 、第 7 、 第10病日に再開腹し、メッシュと周囲組織の経時的変 化および固定状態を肉眼的、組織学的に観察した。

[結果と結論]プローリンメッシュ周囲の肉芽形成は、 第 5 病日より始まり第 7 病日から第 10 病日にかけてほ ぼ完成した。肉芽形成が完成するまでの期間のヘルニ アステイプラーによる固定は安定しており、両者を組 み合わせた壁補強は合理的な術式と考えられる。

\section{示-62腹壁瘕痕ヘルニア手術症例の検討 名古屋市立大学第 2 外科}

川村弘之, 片岡 誠, 桑原義之, 三谷员已 加帛健利, 佐藤䉆司, 服部浩次, 中野浩一郎 隅田英典；木村昌弘，西脇巨記，加藤丈博 成田 清, 小山浩, 正岡 昭

腹壁瘕痕へルニア手術75例を検討した。男性 15 例， 女性60例で女性に多く，平均年龄は57.1藏であった。 腹壁㾥痕へルニア発生の原因手術は産媂人科領域 18 例, 虫垂炎16例，胆道系13例，胃切除9例，イレウス5例， 大渴切除4例であった。開腹創別では上腹部正中 20 例， 下腹部正中 22 例, 上下腹部正中 7 例, 右下腹部18例であ った。腹壁痕痕へルニアの発生の原因手術術後合併症 は創感染 12 例, 同一創開腹 4 例, 術後創多開2例の計 18 例で，発生原因の多くは閉腹手術操作に起因すると考 えられた。開腹創別のへルニア発生部位の特徽は, 上 腹部，下腹部正中いずれも，創中央部が55\%と高事で， 次いで腈周囲 $31 \%$ あっった。ルニア門の平均長径は， 下腹部正中㓣の中央部で最も大きかった。既住手術か らへルニア発生までの期間は, 上腹部正中創で 1 年以内 の早期発生が多く, 右下腹部創では 11 年以降の晚期発 生が多かった。手術終了時にはそれぞれの疾患におけ るへルニア発生の可能性を十分に考虑し閉腹すること が重要である。

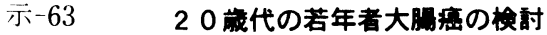

国立大阪病院外科

中川英刀、吉川豆誼、三崲秀行、柳生俊夫、辛栄成、

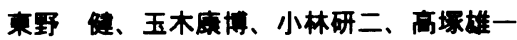

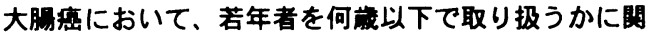
して刑端の多いところである。1966〜1993年の 間に当科にて手術を施行した 2034 例の大嵒度におい て 5 年生存率でみると、40耀以上 $57 \% 、 30$ 耀代 5

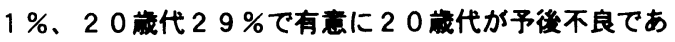
った。そこで 30 成末满を若年者とし、その裙床病理学 的検討を 30 就以上の非若年者群との比較にて行った。

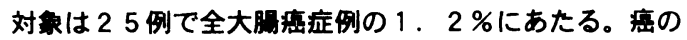
発生部位では、右半桔㴔が $6 \%$ て、同時性多発度の割

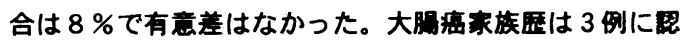
め有意差はなかったか、すべてHNPCCの定媇に合致 した。組穫型では分化型腺癌以外の割合は $16 \%$ で有意 差はなかった。進行度ではstagelV,Vの高度進行癌か 60 \%を占め、非切除に终わった症例の割合は $48 \%$ と有意

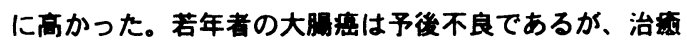
切除できた症例の予後は非若年者と变わらず、また、非 治缌切除症例の 1 年生存率も非若年者と变わらなかっ た。以上より若年者大膘鷹の予後不良なのはその生物学 的悪性度か高いよりも、むしろ発見が㜊れ手術時点で既 に高度進行癌であるためではないかと、考えられる。

示-64大晹signet-ring cell carcinoma(印環細 胞癌） 9 例の検討

癌研外科、同病理 ${ }^{11}$

畦倉恶、上野雅資、太田博俊、中岛㮩縂、

西満正、久保起与子”、柳沢昭夫“、加藤 洋”

[目的]稀な組織型である印環細胞竦の臨床上の特 徵の解明。[対象と方法] 大晹印㻴細胞癌手術症例 9 例（直晹 6 例、結晹 3 例）を臨床病理学的に比较検討。 [結果] 頻度: 单発直晹䄈の約 $0.4 \%$ 、单発結晹煰 の約 $0.25 \%$ 。平均年齛：直晹 47.5 才、䊅腸 6 6. 7 才。性比、肉眼型、理周度、深達度、リンパ節 転移では明らかな差なし。根治度: 直晹で治愈切除 3 例、非治愈切除 2 例（局所 1 、局所 $+N \quad 1$ ）、非切 除 1 例（P）。結晹の 3 例は非治愈切除（いずれも $\mathrm{P}$ ) 。予後：直腸 4 年 8 力月生存中 1 例、 2 年 4 力月 1 例、 1 年以上 2 例、 1 年末满 2 例。結渴では 1 年 1 力月生 存中 1 例、7 7 月および 4 力月各 1 例。再発因子：直 晹の治愈切除例 3 例の再発因子は局所 2 例、 $N+$ 血行 性転移 1 例。なお 4 年 8 力月生存中の直晹痘症例は術 前照射 $30 \mathrm{~Gy}$ と術後亜選択的大功脈注射卖法の施行 例。（まとめ）直晹は平均年踰が低く、治愈切除率も 高く、予後良好。死因は直晹では局所と $N$ 、結晹では $\mathrm{P}$ が重要。また直晹瘦では集学的治療をを併用するこ とで拡大手術の適応となり得る可能性か示唆された。 
示-65大闖数肝枟移症例における原発巣及び

肝転移部のP-glycoprotein 発現の模討

佐世保市立總合病院・外科

西田卓弘、石川綮、暒原辟司、赤間史隆、成松政治 系柳則昭、南宽行、涪田关佐雄、中村淁

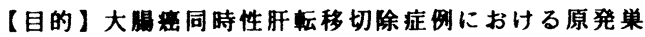
及ひ肝枟移部でのP-glycoprotein (P-gp)の発現につい て、以oAbを用いて兔疫粗化学的に比模討した。 【対象・方法】対象は当科で原発紧・肝転移部ともに 切除された症例（枟移部は試切徐を含む）13侧で、

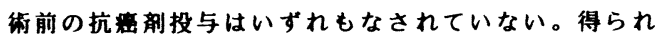
た組槽の凍結切片は、cold4\% paraformaldehydeで固 定。免度染色は $\mathrm{ABC}$ 法にて行い、P-gpに対する抗体は C-219 (Centocor.Inc.) を用いた。【結果】原発巣で は、13例中 5 例(38.5\%)発現隄性であった。肝転移 部では、13侧中 6 测 $(46.2 \%)$ が発現阳性であった。原

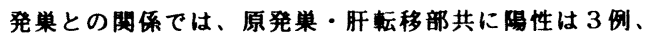
原発策・肝転移部共に陰性は5例、原発紧が隄性で転 移部陰性は 2 例、原発单が陰性で転移部陵性は 3 例に

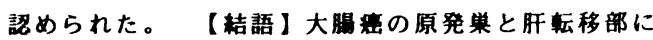
おいてP-gp発現の異なる症例が少なからず存在したこ とは、街後肝移紧に対する化学寮法の効果を予湖す る上で、予め原発巣のみならず肝枟移部におけるP-gp の発現を検討する必要性のあることが示唆された。

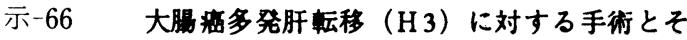
の危険性

秋田大学第一外科

相沢鉴、小棚木均、吉岡年明、柴田裕、

斎藤由理、小山研二

[目的]多発肝転移例では手術後急速に状瑟が悪化 して死に至るものを経凔する。どのような要因のもの がそのような例であるかを検討し、いかなる術式を選 択すべきか考察した。

[対象と方法] H3大渴舟手術34例を対象に、術後急 速に肝病変が、あるいは肝不全が進行して100日以内に 死亡したものをA群（12例）、それ以上の生存例をB群 （22例）として、術前トランスアミラーゼ颠、術前 CEA值、術中出血至、手術時間、術式を比较検討した。

[成耤] A、B両群の肝転移個数に差はなかった。術 前トランスアミラーセ值の比较ではA群 12例中6例 (50 \%) でGOTあるいはGPTが60U/1以上であった。一方B 群で60U/1以上の例は22例中3例 (14\%) にすきなかっ た。術前CEA值、術中出血兵、手術時間、術式の比较 では、西群に差を噁めなかった。

[結諭] 術前のトランスアミラーゼ值高值のもので は、術式や出血量、あるいは他の因子とは间係なく早 期死亡例が多いことから、出来るだけ倛堭の少ない術 式を選択すべきと考えた。
示-67大腸癌肝転移症例の臨床病理学的検討 国家公務員等共済組合連合会広島記念病院 外科 藤本三喜夫, 増田哲彦, 中井志郎, 河毛伸夫, 結城常譜, 上村健一郎, 坂下吉弘

【目的・方法】原発巣に対する根治術の確立された大 腸癌においては肝転移が遠隔成績の鍵をにざっている。 そこで最近経験した大腸癌肝転移62症例（同時性38例， 異時性24例）について臨床病理学的に比較検討した。

【結果】(1)肝転移症例の原発巣は非転移症例に比べ有 意に S 状結腸例が多かった. (2)原発巣が右半結腸では 肝両葉に, 左半結腸ては肝右葉に有意に多く転移を認 めた. (3)治療法別では肝切除例の腫瘍マーカー速やか に正常値まで低下し, 累積生存率も動注化学療法群に 比べ有意に良好であった。（4)異時性肝転移例の 7 割以 上は初回手術後 2 年以内に肝転移を認め, それが 2 年 以降の症例に比べ有意に生存率が不良であった。

【考察】(1)とくに S 状結腸原発の進行癌症例ては肝転 移の可能性を常に念頭に置を，肝右葉を中心とした術 中超音波検査を行い, 症例によっては術中化学療法剂 門脈内注入も考慮すへをと考えられた. (2)肝転移巣に 対しての全身化学療法および動注化学療法の有效性は 確認できず; 原発巣手術後 2 年以内は慎重な経過観察 を行い, 肝切除術適応範囲内の早期に発見し積極的な 肝切除術を行うことか新要と考えられた。

示-68大腸 $\mathrm{s} \mathrm{m}$ 癌治療における医原性問題点の

検討

東京共済病院外科 (1)、昭和大学第 1 病理 ${ }^{(2)}$

後小路世士夫、矢部清寿、宮本洋寿、佐藤雅昭 ${ }^{(1)}$ 、 副島和彦 ${ }^{(2)}$

（目的）大腸 $\mathrm{sm}$ 癌治療の医原性問題について検討する。

(対象・方法) 1994年4月までの11年間に当科で切除し た大腸原発 $\mathrm{sm}$ 癌109例を対象とする。局所切除のみ 31 例 ( I 群)、追加切除39例( II 群)、腸切除のみ39例( III群) に分類し、初回切除方法や機械的侵襲から最終治療ま での間隔について検討した。

（結果）当科では、大腸癌取り扱い規約に則って追加 切除を施行している。I 群中、II群に含まれるべき症 例は3例で、1例に局所再発、肝転移再発を認めた。低 分化癌、経肛門分割切除例である。II群の内訳は断端 陽性2例、脈管浸潤陽性37例、 sm2以上浸潤15例（重複 あり）で、追加切除は全例30日以内に行われリンパ節 転移も再発もない。III群では全例に術前生検診断が行 われており、生検診断から切除までの平均間隔は25.6 日であるが、リンパ節転移3例ではすべてこれを上回り、 2例は60日以上かかっている。

（結語）予後を決定するリンパ節転移や肝転移には、 初期治療の質と最終治療までの対応が大きく関与して いる可能性があると思われた。 
示 $-695 \mathrm{FU}$ 持続静注 $+\mathrm{CDDP}$ 少量反復投与により切 除しえた直腸癌局所再発の一例

市立赤平総合病院外科 ${ }^{1)}$ 、札幌医科大学第一外科 ${ }^{2)}$

縫 明大、古畑智久、渡部公祥 ${ }^{1)}$ 、佐々木一晃、 平田公一2)

直腸癌局所再発例に対して5FU持続静注とCDDP少量反 復投与を行ない切除し得た一例を経験したので報告す る。(症例) 53 才、男性。直腸癌で低位前方切除術の 12 力月 後、左殿部痛を主訴とし当科受診。CEA6. 2ng/m1、CA19$9298.8 \mathrm{U} / \mathrm{ml}$ と高值を示した。骨盤内 CT 検查で、吻合部 に4. $7 \times 3.4 \mathrm{~cm}$ の腫瘍像を認め局所再発と診断した。腫瘍は 尿管を圧排し、仙骨前面に接していた。治疻切除を行なう ために術前に $5 \mathrm{FU}$ 持続静注とCDDP少量反復投与を行なっ た。(方法)中心静脈より $5 \mathrm{FU} 500 \mathrm{mg} /$ dayを79日間持続静注 した。CDDPは $10 \mathrm{mg} / \mathrm{day}$ で週 5 日間投与、その後 $5 \mathrm{mg} / \mathrm{day}$ と減 量した。(結果)化学療法開始3週目から左殿部痛消失した。 腫瘍はCT上 $2.8 \times 1.0 \mathrm{~cm}$ となり、縮小率は $81.2 \%$ あった。 腫瘍マーカー値は正常化した。化学療法中に全身倦意感、 食欲不振を訴えたのみであった。この時点で、治瘾切除可 能と判断し腹会陰式直腸切断術を行なった。手術切除標 本の病理組織学的検討では粘液の貯留巣を認めるのみ で、癌細胞を認めずGrade3の効果を認めた。(まとめ)本治 療法はCDDPの投与量、投与間隔など今後検討すべき課題 はあるものの、有効な治療法の一つであると考えている。

\section{示-70 大腸多発疾、特に大腸癌家族歴淂性 多発虚の検期 \\ 広島大学第 2 外科}

豊田和広、岡島正純、浅原利正、有田道典、 小林理一郎、中原雅浩、正岡良之、小島康知、 伊藤敬、藤高阙生、川堀勝史、土肥雪彦

[目的・対象］近年大腸多発癌はよく経耠され、家族 内発生との関連も報告されている。当科での最近14年間 の大晹多発癌 (37例) について、大腸癌家族歷の有無て 分けて、比較検討した。

[結果] 2親等以内に大腸窝家族歷を認めるもの（陽 性例) は 7 例 (18.9\%)、認めないもの（陰性例）は 30 例 $(81.1 \%)$ であった。性別は陰性例では男性にやや多 く認めた。平均年跉は陽性例て55.9才で、陰性例では 61.2才であり、陽性例で若い傾向にあった。また原煇被 爆歴を調べと、陽性例に42.9\%と多くの被爆歴を認め た。各病巣の癌占居部位は、陰性例では直晹とS状結晹 に46病巣 $(70.8 \%)$ と多く認めたが、その分布は単発癌 とほほ同様であった。一方、陽性例では全大腸に分布し ていた。組織型は陽性例の第 1 癌に高分化腺癌は 1 例も 認めず、中分化腺富が6例であった。

[結語] 大腸多発癌が窝家族歴を有する頻度は高く、 遗伝的因子の関与が考えられる。大腸富家族歴陽性の大 腸多発癌は若年発症て、原爆被爆歷のあるものが多く、 全大腸に分布し、中分化腺癌が多い傾向にあった。
示-71 十二指晹Vater 秚頭部癌を合併した家族 性大腸ポリポージス（F P C）の一例と同疾患におけ る大腸外消化管病変の検討

度応義塾大学医学部外科

千葉洋平、寺本龍生、山本聖一郎、酒井信行、 藤井俊哉、安井信隆、川野幸夫、川本清、渡扨昌彦、 北島政樹.

今回我々は十二指晹Vater 乳頭部癌を合併した F P Cの一例を経験したので若干の文献的考察を加え報告 するとともに、当教室において経験したF P C 30 症 例（1970年～1993年）の大腸外消化管病変に ついて検討した。 [症例] 59 歳男性。経過 ; 昭和 4 8 年家族性大腸ポリポージス（F P C) に対し大腸亜 全摘術施行、以後当院にて経過観察されていた。平成 6 年 2 月残存直腸ポリポージス精查加度目的にて再入 院となった。消化管精查より十二指晹Vater 秏頭部癌 の合併を確認し、4月 12 日、幽門輪温存膵頭十二指 腸切除術を施行、二期的に残存直晹切除・回晹肛門管 端々吻合術を行った。当教室において経検した F P C 30 症例について検討したところ、大腸外消化管病変 を合併したものは 11 症例（胃 10 、十二指腸 4、回 腸 1 症例、内 4 例に癌の合併を契めた）であった。本 疾患では大腸外消化管病変を合併することが稀でなく、 経時的な大腸外消化管病変の検索が必要と思われた。

\section{示-72 悪性リンバ腫を疑った腫瘦形成大腸炎の \\ 1 例} 市立稚内病院外科1）、国立札幌病院病理 ${ }^{2)}$

越前谷勇人、浜田弘巳、上泉洋、山本急治、青木贵德、 宮田睦彦、高木知敬 ${ }^{1)}$ 、山城勝重 ${ }^{21}$

（はじめに）炎症性腸疾急の病態についてはかなりの ところまで明らかになってきているが病癿が不明な例 も多い。今回我々は腫㾔を形成した非特異性大腸炎の 1 症例を経铪したので報告する。（症例） 22 歳、男 性。（主訴）右下腹部痛。(現病歴) 平成 6 年 1 月よ り右下腹部痛出現するも放正していた。3月14 日当 科受診、入院となった。（入院時検査成績）炎症所見 を認めた。（腹部CT模査及び大渴内視鏡検査）上行結 腸に全周性䏦瘠を認めた。生湌にてMalignant lymphoma が疑かれた。(手術) 結腸右半切除術を行った。（組 䋘所見）高度な炎症を認めたが黑性所見はなかった。

(考察) 1986年武藤らは次症性腸疾患を 1 、感染症 $2 、$ 感染以外で原因が証明される炎症 3、原因不明だが疾 患単位として碓立されているもの 4、分類不能な晹炎 の 4 つの型に分類した。今回我々が経覽した症例は、 分類不能な晹炎に属するが、腫癌形成例は、検索しえ た籍囲内では認められなかった。腫瘠を形成する非特 異性大腸炎の病態把握のためには、本例のような症例 の積み重ねが必要であると思われた。 
示 -73

两的大野望室症の柃討

帝京大学第 1 外科 ${ }^{1)}$, 社会保険埼玉中央病院 外科 2)

三浦誠司 ${ }^{1)}$, 野沢屡次郎 ${ }^{1)}$, 青木久巷 ${ }^{1)}$, 三重野 寛治 ${ }^{1)}$, 小平 進 ${ }^{1)}$, 前田耕太郎 ${ }^{2}$ )

[目的ならびに方法] 11 年間に施設2)で行った注腸 検査7、543例を前、後期に分けて見直すことにより、

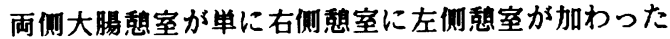
ものか，あるいは固有の分布を示すのかを検討した. [成績] 両侧憩室の、(1) '発見頻度” の年秢別分布 は左侧憩室に類似したが，年次別には右侧憩室に似 て中年で後期に增加していた，(2)大腸右半に分布す る蒩室 “数”は，右侧嚊室より多かったが、左半に 分布する数は，左侧憩室と差がなかった，他方、(3) 大腸右半と左半にみられる馝室数の相関は低かった。 (4)大腸右半の燱室数は年粭別, 年次別にみて変化に そしく右侧喤室と同核であったが、左半にみられる 数は有意差はないが加粭とともに，また後期に增加 する傾向がうかがわれ，左侧頢室と異なっていた。

[結論］大腸の左侧に覟室が㘿えているのは、左侧

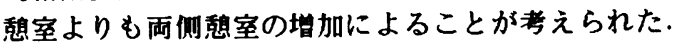

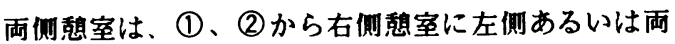
侧の憩室が加わったものと解积しえたが、(3)、(4)か ら央侧嚊室が固有の分布を示すことも否定できない.

\section{示-74当院における大腸穿孔手術症例の检討} 德島県立三好病院外科

安藤 趿、高井茂治、高木敏秀、三村誠二、拫 正宏 藤逢正昭

[目的］当院における大腸穿孔の手術症例を検討し、 術後 4 用閒以内の死亡の術死例の特徽と、当院の地域 的特色について検討したので報告する。

[方法] 平成元年 9 月から平成 6 年 8 月までの 5 年間 に経験した大腸穿孔手術症例 22 例を対象とした。同 期間の胃十二指腸および小腸穿孔例とも比較検討した。

[成績] 固十二指腸は 23 例、小腸は 18 例、大腸は 22 例で、大腸穿孔の比率が高かった。平均年令も高 く、女性の占める割合が高かった。腹㓐内遊離カスの 出現は、 $50.0 \%$ 、術死率は $36.1 \%$ だあた。大腸穿 孔症例では、術死群が平均年令も高く、男性の割合も 高かった。原因は、大腸疼 3 例、㓤室 8 例、虚血性 3 例、放射性 1 例、良性渭富 1 例、外倩 3 例、特発性 3 例であった。平均手術時間は術死群が3.3時間、生存群 が2.7時間であった。症状発現から手術までの平均時間 は、術死群が43.5時間、生存群が16.8時間であった。

[結論] 当院では腹部消化管穿孔症例中大腸穿孔の比 率が高く、その原因疾患では大晹虫の占める割合が低 かった。その予後因子として、年令、性差、手術時間、 症状発現から手術までの時間か関与していた。

\section{示-75 当院における大腸穿孔例の検討}

健康保険南海病院 外科

中村 彰、田原光一郎、立麻敏郎、亀川隆久、 秦 良平、恒松芳洋

（目的）大腸穿孔は、汎発性腹膜炎をおこし予後不 良となることも多い疾患である。今回、当院における 大腸穿孔例について臨床的に検討したので報告する。

（対象）1985年10月より1994年 5 月までに当院で経 験した大腸穿孔14例（虫垂穿孔を除く）について、年 粠、穿孔の原疾患、穿孔部位、術前診断、手術方法、 予後等の検討を行った。（結果）年齢は30歳から96 歳、平均66歳で男性 8 例、女性 6 例であった。穿孔の 原疾患は、特発性が 8 例、医原性が 2 例、大腸癌、外 傷性、異物、クローン病が 1 例ずっであった。穿孔部 位は、S 状結腸が10例（71\%）と最も多く、次いで、 横行結腸 3 例 (21\%)、上行結腸 1 例 ( $8 \%$ ) であった。 腹部単純 X線写真で腹腔遊離ガスを証明出来たものは、 14例中10例 (71\%) であった。死亡例は 2 例 (14\%) お り、術前にショックを呈していた。手術術式は人工肛 門造設 7 例、閉鎖術 4 例、腸管切除 3 例である。

（まとめ）大腸穿孔は、重篤な合併症を伴う事が多 く、早期診断につとめ、手術侵襲を必要最小限にとど める事が重要と思われた。

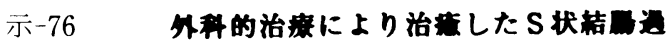

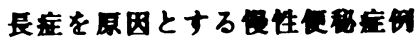

北毛病院外科 群馬大学第一外科1)

根本雅明 小林正則 笹本 管1) 竹内邦夫1)

小意公毒1)

我々はS 状結昌墖長症を原因とする惯性便秘症患者を 手術的に治就せしめたので報告する。

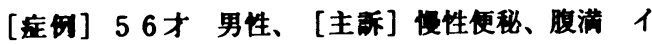

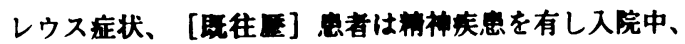

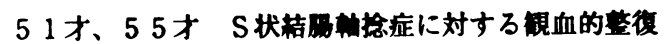

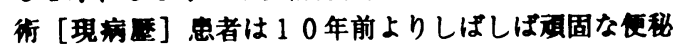
が珫き二度吿血的整復術を受けている。しかし、すぐ

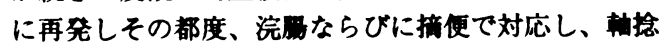
転に对してはsigmoid fiber scopeによるS 状結易の整復 を行っていたが、更に、浿回に高度な耐症を発症す

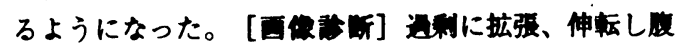

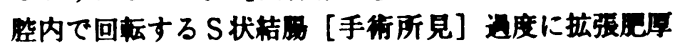
したS状結易が右㑡腹部まで伸展していた。造長な S

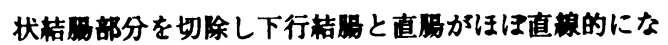

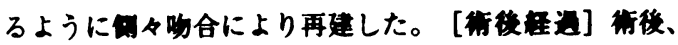

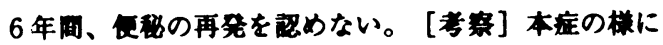
侵性便秘运の原因がはっきりしているものには外科的 な治夷が过択されるべきである。 
示-77 低位前方切除術後難治性排便障害を来たし た症例の分析と対策

福岡高野病院

过 順行, 高野正博 河野洋一, 徳嶺章夫

〔目的〕低位前方切除術（LAR）後に 1 年以上も頻 便症状の改善しない症例の原因と対策を検討した.

【対象】当院 他院にてLAR施行後に 1 年以上も排 便回数 7 回 /day 以上の 8 例を対象とした。【万法〕 精神面のケースワーク，結腸直腸朋門機能検查を行な い，対照群にも同様な検查を施行した。治療は精神的 サポート, バルーン拡張術, バイオフィードバック療 法（ＢＩＯ），腸管運動抑制剤投与を行った。結果〕 （1）精神的サポートが重要視された。（2）1 年以上経 過後も有意にコンプライアンス, 最大耐容量, 便意発 現最小量は低く，直腸肍門角は高かった。バルーン拡 張術，ＢＩＯを行ない3例が退院した。（3）2例に吻 合部狭窄を認め, バルーン拡張術により排便回数が減 少した。（4）7例に吻合部口側腸管の運動六進による 機能的狭窄とマーカーの結腸口側部で停滞を認めた。 腸管運動抑制剂を投与したが 4 例で効果がそしかった。 〔結語〕術後頻便症例の腸管は吻合部か硬化し，残存 腸管も含め直線状となり，それより口肛側の機能的狭 窄が加わって, 腸内容が少量つつ残存值腸に移動し頻 便を来たすと考え，これをBＩＯ等により改善できた。

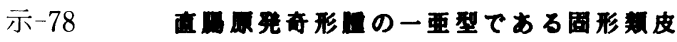

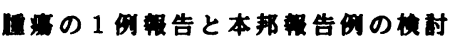
松田痛院外科"，，神戸大医学部保健 ${ }^{2}$

常見幸三”，松田起功”，多洲芳救"

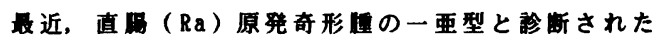

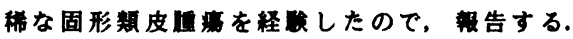

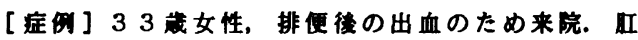

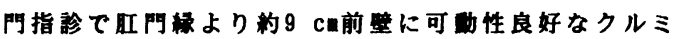

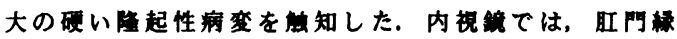

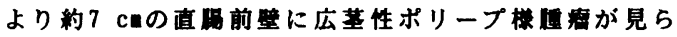

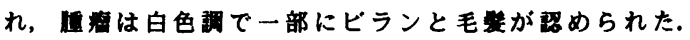

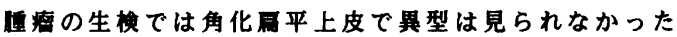
ため,内視鏡的に摘出した。墒出梅本は $2.5 \times 2.1 \times$

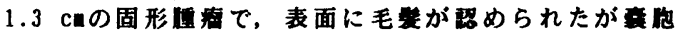

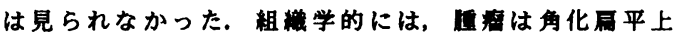

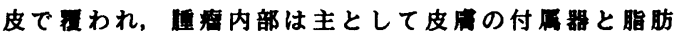

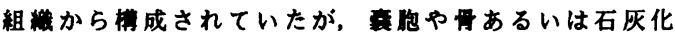
は見られなかった．以上の所見より，直间原発の成篎

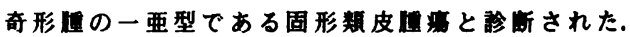

[結浯] 本邦では，1914年以降本例を含め12湖の直

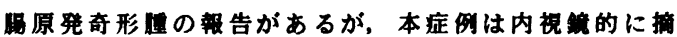

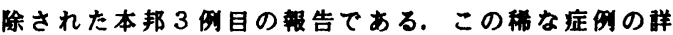

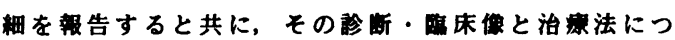

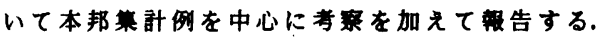

示 79

直腸原発M A L T リンパ腫の一例
因岛紹合病院外科、岡山大学第一病理*
奥村武弘、松原淳、岡野和雄、杉本誠起
荻野哲也*

M A L T (mucosa associated lymphoid tissue)リン パ腫は、1983年にその概念が提唱された低覀性度群に 分類される消化管原登覀性リンパ腫である。近年、胃 原発例の報告は增加しているか、、直晹原発は本邦にお いて 2 例しか報告されておらず、極めて稀である。今 回我々は出血性胃潰福により下血を呈した患者の精㚗 中偶然に大晹内視鏡によって小結節状隆起を発見、病 理学的にMA L T リンパ腫と診断し、低位前方切除を 施行した症例を経験した。その病変は、肛門㖮より約 $10 \mathrm{~cm}$ 口側の R a 領域に存在し、表面、性状ともに不整 で、易出血性を認めない小結節状隆起の集族を呈して いた。切除標本では、生検時と同様に中型の腫的細胞 が粘膜深層から粘膜下層にかけて増殖し、一部に lymphoepithelial lesionの形成を認めた。病理的に 完全切除と考えられた。本症例は、両鼠佳部を除いて 表在リンパ節を触れず、胸・腹部 C Tでもリンパ節腫 大を認めなかった。また鼠经リンパ節生検で覀性所見 を認めないことから、直腸原発と考えられた。本症例 をMALTリンパ腫の治療を中心に、若干の文献的考 察を加えて報告する。

\section{示-80 ダグラス窩腹膜原発CA-125産生腺 癌の 1 症例}

\section{公立昭和病院外科}

岡田晋吾, 祁答院尚嗣, 坂本直弘, 山崎健, 荒深景一, 森田恒治, 河原正樹, 矢羽野壮光, 前田正之，浅倉禮治，荒木駿二，北條慶一

【症例】54歳, 女性. 以前より排便困難があったが 1993年 1 月より便秘がひどくなったため当院受診さ れ，注腸検查にて直腸の後方よりの圧排が著明に認 めらたため婦人科疾患疑われて，入院となった。

【入院経過】一般血液検查では特に異常を認めなか めなかったか， CA-125は17,401U/ml と異常高値で あった．またC Tでダグラス蒚に大きな ma s s を認めたため, 卵巣腫瘍之診断された.

2 月 11 日に婦人科にて開腹し，術中の所見で外科 にて人工肛門造設術のみを行った．その後検査を行 い再度 3 月 11 日に開腹し, 後方骨盤内脿全摘術 行った． 組織学的検索では腺癌の像を認め，またCA -125の産生が免度染色で確認された。婦人科䐬器に 異常は認めず，直腸も穿孔を認めただけのためダグ ラス窝腹膜原発の腺癌と診断された.

【結語】今回我々はタグラス窝腹膜よりでたCA125産生腺癌の珍しい1例を経験したので若干の文 献的考察を加えて報告する. 
示 -81

後腹嗼原発の著明な下大静脈佩位を伴う

alveolar soft part sarcomaの切除例

国立大阪南病院外科

过毅、田伏克惇、杉本患洋、森一成、

岡正已、朝野挖、尾崎敬、平井久也

（目的）後腹䀧に原発し著明な下大静胉の偏位と肝尾

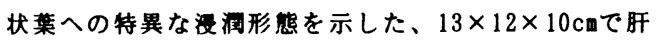
尾状葉も含め770gの切除し得た、alveolar sof t part sarcomaの㱏例を释験したので報告する。

（症例）63盛女性、主訴は悪心を伴う上腹部痛で、腹 部CT、MRIでは、後腹䀧の石灰化を伴う内部不均一な榊

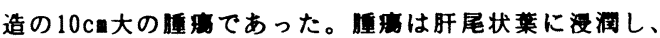

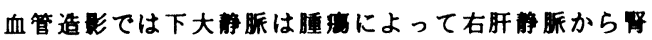

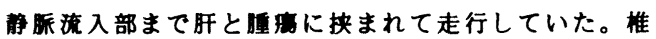

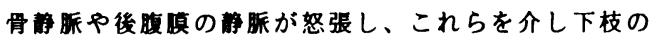
血流が循㻓していた。1994年4月、biopump・体外灌流

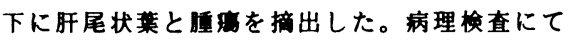

alveolar soft part sarcomaと參断した。

（考察・結語）本疾患は後腹瞙腫捣の 2 3 的にeosin好性から明るい細胞爱をもち、granule はPAS染色陽性で消化PASにて消化されず、骨格筇肉腫 に類似した軟部腫的で、若年の女性に多い。60成以上 での発定の報告は本例とともに2例で、遠隔転移もなく 特異的な発育を示した非常に稀な治呀例であった。

示-82外科治療により治意した大腸膀胱瘦の

3 治釦例（結晹点室资、クローン病、放線菌症） 越谷市立病院外科

三上陽史、渡部洋三、津村秀憲、松本文夫、石引佳郎

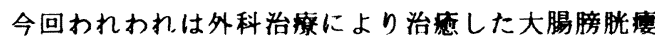
の 3 症例を経拿したので報告する。

症例 $1: 52$ 歳、男性。咩治性尿路感染症の診断で必 尿器科で投薬治療を受けていたが、层中に食物残渣の 出現を認めたため晹管膀胱度を筑われ当科入院。膀腅 鏡、注晹造影、大晹内視鏡検査の結果、結晹㕰室炎に

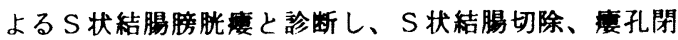
鎖術を施行した。

症例 $2: 23$ 葴、男性。クローン病の診断で他院で保 存的治療を受けていたが症状改善せず当科入院。注腸 造影、大腸内視镜検直の結果、クローン病による回腸 㹟窄、S 状結腸膀腅瘦と診断し、S 状結切除、回晹部 分切除、度孔切除術を施行した。

症例 $3 \because 46$ 瓷、男性。覲治性尿路感染症の診断で泌 尿器科で投菜治療を受けていたが症状改善せず、膀胱

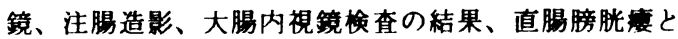
診断され当科入院、低前方切除、瘦孔切除術を施行し た。病理組筬学的検查にて放線菌症と診断された。

3 症例とも術後の経過は良好で、再発の勧候もなく 現在外来通院中である。
示-83結腸結晹雃を形成した大腸癌の 2 例

関東中央病院外科

杉下岳夫, 高田厚, 田中一成, 山下宏治

【症例 $1 】 81$ 墄女性。負血および左側腹部腫瘤を主 訴に来院した。注腸造影では下行結晹癌または横行結 晹癌で、両者の間に内撴が形成されていた。結腸左半 切除術を行ったが、切除標本の肉眼所見は 2 型の横行 結晹癌とそれに伴う横行結晹への内㾑形成だった。組 織所見では高分化腺癌でsen(-) 1y0v0だった。

【症例 $2 】 57$ 歳女性。発熱および腹痛を主訴に来院 した。術前の大晹内視鏡検査および注腸造影の結果、

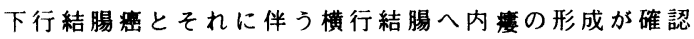
された。結腸左半切除術を施行したか、切除標本の肉 眼所見は 2 型の下行結晹癌でその潰瘍底から横行結腸 に続く内敦が確認された。組織所見では高分化腺癌で sen(-) 1y1v0だった。

【考察】大晹癌に内裳の形成が合併することは少な い。今回の 2 症例の組䢂所見において、はなはだしい 浸蘭像が認められるわけではなく、単純に癌が近接し た結腸に浸潤しただけで内陣が形成されたとは考えに くい。特に症例 2 は多発款室を有し、また、内瘦の組 織所見において筋層が欠如していたことから、䚑室の 関与が考えられた。

示-84大腸原発 paraganglioma（傍神経節腫）

の 1 切除例

高松赤十字病院外科 ${ }^{11}$, 婦人科 ${ }^{21}$

石倉久嗣 ${ }^{11}$, 三浦一真 ${ }^{1}$, 森田純二 ${ }^{11}$, 吉澤 潔 ${ }^{1}$, 高橋裕先 ${ }^{11}$, 新田次郎 ${ }^{21}$, 原田 攻 ${ }^{21}$

paragangliomaは, 副腎外の傍神経節由来の腫瘍で, 消化管からの発生は稀である。消化管発生のうちほと んどが十二指腸近傍からで, 大腸原発のものは文献上 報告されていない，今回我々は，本症の一例を経験し たので若干の文献的考察を加え報告する.

【症例】患者. 33歳, 女性. 主訴. 下腹部痛, 頻尿, 平成6年5月上句, 上記のため当院受診, 精査にて卵单 腫瘍と診断され入院. 6 月9日手術施行. 卵巣, 子宮に は異常なかった，腫瘍はS 状結腸の腸間膜付着部分よ り発生しており，術中迅速組織診にて肉腫が疑われた ため，腫瘍を含めた S 状結腸部分切除を施行した．腫 瘤は小児頭大で，割面では輁胞性部分と充実性部分が 混在していた。病理組織所見では，腫瘍細胞は核小体 明瞭で大きな核と広い好酸性顆粒状の胞体を持ってい た. 免疫組織化学より, paragangliomaと診断された。

【考察】消化管発生の傍神経節腫は良性腫瘍と考えら れているが，大腸からの発生の報告はないため予後な ど詳細は不明である。しかし，十二指腸発生で悪性例， 転移例の報告もあり，箃重な経過観察が必要である。 
示-85 30 年間に 4 回切除しえた異時性多発大 腸癌の 1 例

\section{国立岩国病院外科}

田中屋宏爾、小長英二、竹内仁司、漆原直人、 安井義政、柚木靖弘、吉岡 孝、西崎正彦、村上敬祥、 川嶋健、深澤拓也

【症例】61歳、男性。【現病歴】平成4年 12 月、大腸 癌術後の定期検査にて大腸隆起性病变を指摘され入院 した。【家族歴】兄：直腸癌、73歳。【既往歴】(1)昭 和 39 年 2 月、盲腸癌 : 回盲部切除術。(2)昭和 48 年 12 月、 横行結腸癌：横行結腸切除術。(3)昭和58年9月、S 状 結腸癌：S 状結腸切除術。【現症】特記すべき異常な し。【検査成績】一般血液検査：特記すべき異常なし。 $\mathrm{CEA}: 8.1 \mathrm{ng} / \mathrm{ml}$ 。肛門縁より $12 \mathrm{~cm}$ の直腸に径 $2.5 \mathrm{~cm}$ 大の 隆起性病变を認めた。生検の結果はGroup5。【手術】 直腸癌、Rs'、0’型、I ' $^{\prime} 、 S M^{\prime} 、 \mathrm{P}^{\prime}(-) 、 \mathrm{H}_{0}{ }^{\prime}$ 、 $N^{\prime}(-) 、 M^{\prime}(-)$ の術前診断にて、内視鏡的切除術 を試みたが遺残が疑われ、開腹下に腫瘍切除術を施行。 術中所見でリンパ節腫大は認められなかった。【組織 学的所見】高分化腺癌 (adenoma in carcinoma)、sm、 $1 y_{0} 、 v_{0}$ 。【経過】 4 回目の大腸癌術後 1 年半を経過し た現在も再発の徴候なく外来にて経過観察中である。

【考察】本症例の様に大腸癌術後に長期経過観察の必 要となる症例について文献的考察を加え報告する。

示-86腸重積を来した盲腸の転移性無メラニン色 秦性悪性黒色腫の一例 市立貝塚病院外科

川端雄一、川崎勝弘、岩本伸一、中野芳明、西 敏夫、相沢青志、森 武真

盲腸への転移病巣が晹重積を来したために診断がつ いた爪床部原発の悪性黒色腫の一例を報告する。

【症例】57歳女性。

【主訴】右季肋部有痛性腫瘤。

【既往歴】平成 4 年 2 月、左第 1 趾爪床部の小腫痹の生検 で転移性低分化腺瘦と診断された。同年4月、腫脹した 左大腿リンパ節を摘出、組織学的診断は転移性悪性黒 色腫であった。双方ともに原発巣不明であった。 【現病歴】平成6年1月頃より腹痛出現し、近医受款、精 查にて大腸痘による腸重積が疑われ手術目的で再入院 となった。大晹内視鏡にて、盲晹にBorr mann I 型の 腫演を認めた。転移性低分化腺磨の原発部位は盲晹と 考元右半結晹切除術を施行した。組織学的には、兔度 染色にて、EMA䧔性、S-100陽性、HMG-45陽性であり、無 メラニン色采性悪性黒色腫之確定晾断でき、爪床部腫 痹の組織の見直しでこれが原発柴と考えられた。 【考察】悪性黒色腫の消化管転移について、若千の文献 的考察を加え報告する。
示-87直得花を合併したCrohn 病の 2 例 福岡大学筑紫病院外科

長谷川修三,二見喜太郎,山崎宏一,岡本達生,有馬純孝

今回われわれはCrohn 病の診断後,各々,7 年,10年を 経て直腸癌を合併した 2 例を経験したので報告する. 症例 1 は44歳,女性.24歳時.37歳時,Crohn 病と診断され ている.1989年7月(44歳時), 外陰部痛および腔の腫瘤を 自党,1990年1月,腫瘤増大,当院入院となった.入院時,胵 よりカリフラワー様腫瘤が露出しており,下部直腸肛 門管前壁側中心に硬く可县性のない腫瘤を触知した.2 型直腸癌,膰浸润と診断し同年2月28日, 直腸切断術, 子 宮,腔合併切除を行った.病変はRb P,2型, 粘液变性を伴

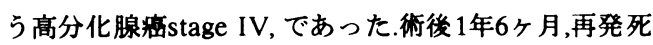
亡した.症例2は31葴,女性.21歳時,Crohn 病と診断され, 24歳時,右半結腸切除術をうけている.1990年(28歳時) 頃より肛門部腫瘤を自觉している.1993年6月,全身倦态 感,肛門部出血,発熱がみられ,10月26日,症状增悪し当院 入院となった.肛門部腫场はカリフラワー様隆起を呈 し、下部直腸・肛門管は長径 $11 \mathrm{~cm}$ にわたり,びまん性狭 窄がみられスキルス型虎と診断した.11月15日手術施 行,骨盤腔内に直腸,子宮,胵と一塊となり巨大腫瘤を形 成していた.直腸切断術, 子宮,胵, 尿道の合併切除を行っ た.組織所見では粘液癌 stage IV,であった.2症例とも組 織学的には非癌部には細胞異型はみとめなかった。

示-88結朋間膜内に穿破した特発性 $\mathrm{S}$ 状結膶破裂

の 1 例

新城市民病院外科 1)，同消化器内科 2)

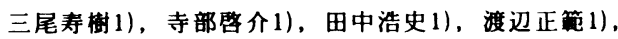
津荷龍生 1), 飯塚昭男2)

今回我々は術前の特徽的な画像所見から結間間膜内 に穿破した特発性 $\mathrm{S}$ 状䊅䦪破裂と診断した，きわめて 稀な1例を経鑍したので報告する。

症例は 67 歳, 女性で, 主訴は下腹部痛と下血であ る。4-5 日前より便通がなく, 平成 6 年 6 月 6 日市 販の浣晹薬を使って硬便を排泄，その後血便と眭度の 腹痛のため救急車で当院に来院した。入院時所見は高

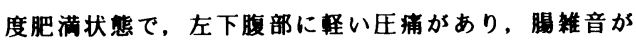
娍弱していた。䋈急内視鏡の結果, 肛門緑より $25 \mathrm{c}$ $\mathrm{m}$ の $\mathrm{S}$ 状結聞に大さな粘膜欠損とその欠損部には小血 管を含む脂肪組機が認められた。さらに注渴では $\mathrm{S}$ 状 結渴の部分から造影剂が流出し, 円形の㩊放样陰影を 形成した。以上から結閶間膜内に穿破した $\mathrm{S}$ 状結晹破 裂の診断で緊急手術を行い, S 状結晹の切除術とHart mann手術を施行した。特発性 S 状結渴破裂のほとんど が腹腔内への遊崔穿孔であり，本症例のように閶間膜 内へ破裂した症例はきわめて稀である。また，本例は 来院時監床所見に乏しく，特徽的な内視鏡所見と注珹 像が術前診断に有用であった。 
示-89白血病治寮中の骨触抑制期に発应した急 性腹应に手術的治度を施行した 2 例 町立木曾川病院外科 ${ }^{11}$ ，汥阜大学第 1 外科 ${ }^{2)}$

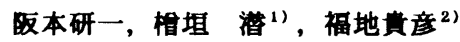

【はじめに】骨触抑制期にある造血器圆薄に併発した 急性腹应では手術䢔応の決定が困萦である。今回, 白 血病経週中に発症した大渴想室炎と急性虫垂炎を各 1 例経臤したので報告す。【症例 $1 】 46$ 虔，女性。白血

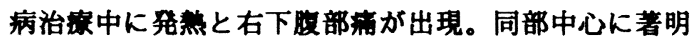
な压痛, Blunberg氏徵侯，助性防御を認め, WBC 2000 $/ \mathrm{m}^{3}$, Ht $21.4 \%$, Plt $3.1 \times 10^{4} / \mathrm{m}^{3}$, CRP $18.3 \mathrm{mg} / \mathrm{dl}$, 出血時間 1 分30秒, 固時間 6 分30秒。止血は良好で 右半結鹏切除術を施行。上行結腗口俔部に数個の穿通 性仮性息室を認めた。【症例 2】68歳, 女性。白血病

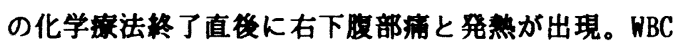
$400 / \mathrm{m}^{3}$, Ht $25.3 \%$, Plt $2.2 \times 10^{4} / \mathrm{m}^{3}$, CRP $8.1 \mathrm{mg} / \mathrm{dl}$ 。 急性虫垂炎と診断し虫垂切除術を施行。【考察】両例 とも骨垥抑制期に発症したまれな症例で，沉発性腹膜 炎への進展を危惧しクリーンルームで手術を施行し術 後管理もクリーンルームで行った。いずれも白血病治 㾣が再閒でき手術的治案は有效であつた。病期を問わ

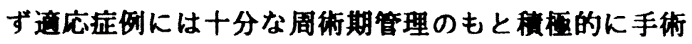
的治察を施行することが必要であると考えられた。

示-90较扼性腸閉塞を発症した成人回盲部消

化管重複症(分触型)の1例

爱媛県立中央病院外科

根津賢司、酒井堅、河崎秀樹、喜安佳人 木村誉司、重松 授

奥島病院

奥島伸治郎

【緒言】成人の回盲部の消化管重複症で较扼性腸閉塞を 発症した1例を報告する。【症例】27歳、男性。主訴は腹痛 で現病歴では1994年3月24日早朝から心召部痛があり、 腹部全体に広がり絞扼性腸閉塞を疑われて当院を紹介 された。腹部局所所見、腹部X-P、CT scanで絞扼性腸閉 塞を疑い緊急手術を施行した。手術では回盲部の晹間 膜上に腸管とは離れた位置に半透明の薄い膜様物を有 するソーセージ様の亚腫があり、この膜様物に裂孔があ り回腸末端が約 $60 \mathrm{cn}$ 陷入し絞扼されていた。袁腫を摘 出し埭死腸管を切除して手術を終えた。言腫は7.0×2.0 cmで腸管と同じ外钼で、内部に半透明の粘液様物質が あった。病理組樴所見では素腫壁は小腸の棈造と一致 していた。【考察】Laddらの定義に池田らの定義を加味 して考えると、本例は回盲部の分䧻型消化管重複症と 考えられた。結語】稀な成人回盲部分離型消化管重複 症の1例を経质したので文献的考察を加えて報告した。
示-91 Segmental 01 igoganglionosisたよる成人

巨大結暍症の 1 例

石川具済生会金沢病院外科

川上和之、川浦幸光、川上卓久

下行結鹃のSegmental 01 igoganglionosisによると考

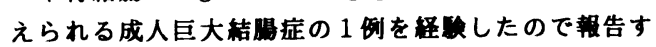
る。症例は 27 瓷男性。平成 6 年 1 月より訶因なく便 䂗となり、1 カ月间排便を彯めず近医入院し保存的治 暴を受けた。その後も便秘傾向は綂き、7月に再び 1 力月间排便を琵めず、当科绍介された。初喰時展部は

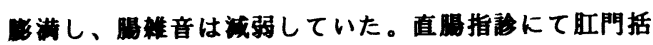

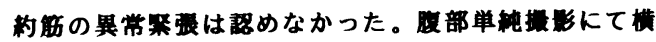

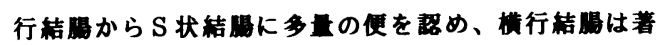

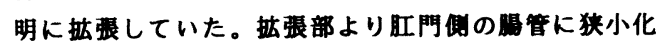
は琴めなかった。直岛粘莫の生检にて異常を認めなか つた。入院後の保存的治康にても排便はみられず、特 発性巨大結量症を策い平成 6 年 7 月 28 日結量左半切

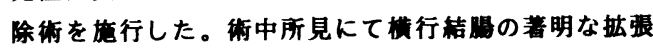
を㑇めたか、これより肛門僋の筍に著变を瑟めなか

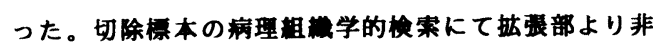

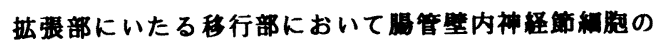
着明な娍少が琴められSegnental 01 igoganglionosisに

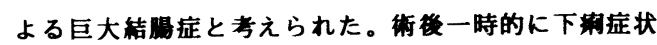

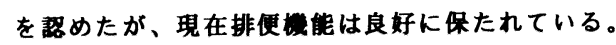

\section{示-92結腸脾彎曲部捻転症の一例 山口赤十字病院外科}

大谷和広、島田和生、安部健司、的場直行

藤井瓶正、佐藤和洋、增田弘志、井上 強

症例は49才、女性。受診1週間前より排便がなく、腹 痛、嘔吐が出現したため入院となった。腹部は全体に著 明に膨渵し、左季肋部に圧痛を認めた。腹部単純撮影で 脾彎曲部より口側の結腸の著明な拡張、逆行性大腸透視 で脾彎曲部直下の下行結腸に「鳥のくちばし」様の狭窄 を認め、イレウスの診断にて同日䋈急手術を施行した。 開腹すると、結腸が脾彎曲部において反時計回りに約 180 度捻転し、横行結腸は径 $9 \mathrm{~cm}$ と著明に拡張していた。 胃結腸、脾結腸靶帯は久如し、横隔結腸勒带も内側へ童 引され菲薄化していた。結腸の捻転を整復したのち、疫 痕化した捻転部での屈曲を防ぐため下行結腸を一部、後 腹膜より遊離した。術後2、4週目に、脾彎曲部での通過 障害が原因と考えられるイレウスを起こしたが、いずれ も保存的に改善した。その後は緅下削にて排便をコント ロールし、術後20ケ月経過した現在、再発は認められて いない。脾篔曲部での結腸捻転は極めて稀で、本邦でも 2 例が報告されているにすぎない。遇去の報告では、捻 転の整復のみを行い切除を行わなかった症例に再発例が 認められているが、本例では排便をコントロールするこ とによって、良好な結果が得られている。 
示-93 PTHRPによる高カルシウム血症をおこし た肛門管癌の一例

柏市立柏病院外科 ${ }^{1)}$, 同内科 ${ }^{2)}, \mathrm{PCL}$ 病理 ${ }^{3)}$

延澤 進 ${ }^{1}$, 松本日洋 ${ }^{1}$, 佐藤彰治 ${ }^{1)}$, 山田隆司 ${ }^{2}$, 田中 昇 ${ }^{3)}$

症例は 60 才男性で, 注腸造影, 大腸内視鏡で, $\mathrm{Rb}$ $\mathrm{P}$ の直腸癌と診断した。1993年 12 月に, 腹会陰式直腸 切断術, 頝部リンパ節郭清, 大動脈カニューレーショ ンを施行. 手術診断は, $\mathrm{Rb}-\mathrm{P}, 3$ 型, $\mathrm{Ai}$ (前立腺), $\mathrm{P}_{0}$, $\mathrm{H}_{0}, \mathrm{~N}_{4}(+)$ : 傍大動脈リンパ節, $\mathrm{M}(+)$ : 頚部リン パ節の直腸癌. 組織象は, Cloacogenic Anal Carcinoma のTransitional Cell Typeで, 多数の核分裂像 を認め, きわめて高い悪性度を示した. 術後約 70 日で, 血清カルシウムが急激に上昇し, 補液, カルシトニン, ステロイド, 利尿剂等の治療にもかかわらず, 術後約 100 日, 高カルシウム血症発症後約 1 カ月で死亡した. 血漿 PTH-intact は著減し，血漿PTHRPは著明高値 を示し，免疫組織染色で癌細胞にPTHRP が陽性を示 した事より, 腫㾴細胞が産生した PTHRPによりひき おこされた体液性高カルシウム血症 (HHM) と判明し た．大腸癌の HHM は非常にまれで，直腸癌の HHMは 世界で 3 例の報告を見るのみであり，肛門管癌の報告は 本例が世界で第 1 例目である.

\section{示-94 $\mathrm{S}$ 字結腾癌の同時性副骨転移の 1 切除侧}

国立水戸病院 外科

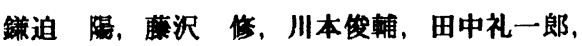
柴崎信悟，俣野一郎，村上程

【はじめに】大胆癌の同時性副骨転移で，根治的切除 可能例は極めて稀と思われ報告する，【应湖】71才，女 性. 現病歴：94年4月初頃より腹痛みられ来院入院す。

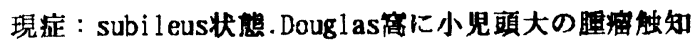
す. CEA $24.3 \mathrm{ng} / \mathrm{nl}$. C T像：右等上極に接して所後 区域に一部骎濯のみられる6x5 cnのSOLあり.血管造影

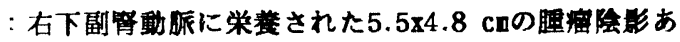

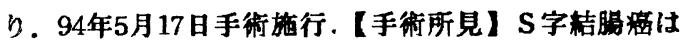
直腈(Rs)および子宮に直接浸澗みられ, en-blocに合併 切除す。右副等腫激は右等脂肪被膜および肝後区域を 一部合併切除して摘出す．【切除標本所見】S 字結渴: $6.5 \times 5.0 \mathrm{~cm}, 2$ 型, circ，高分化膰癌，si（子宮）, INF $\gamma$, $\mathrm{n}_{1}(1 / 15), 1 \mathrm{y}_{2}, \mathrm{v}_{2}, \mathrm{P}_{0}, \mathrm{H}_{0}$, 右副等: $6.5 \times 5.0 \times 3.5 \mathrm{cr}, \mathrm{M}(+)$, stage $N, D_{3}$, 根治度B.【術後経遇】術後3个月CEA 0.2ng /田1と低值で健在.【まとめ】大腸癌の副骨転移は剖検 例ではしばしばみられるが，切除例の報告は，過去3年 間に界atatani et alの異時珄の输移3佃の報告がみら れるのみで，同時性の転移の切除例は柾めて稀と思わ れ，文献的考察を加え報告する。
示 -95

癌の 1 例

国立只病院外科、同呼吸器外科*

船津俊宏、中場寞行、濱路政靖、越智昭博、 長岡道希夫、中室 誠、北川 透、水島恒和、 金 釾国、盤井成光、中村憲二* 、鳥 正幸 ${ }^{*}$ 同時性:肝肺転移を指摘された若年者直腸癌症例に対 し、直腸、朋、肺同特切除を行い、良好な経過を得た ので報告する。症例は28才女性、主訴は下腹痛及び便 秘。約1年前より時々下腹痛を白覚したが妊娠中で放 置していた。しかし出主後も下腹痛が続いたため来院 した。注腸、大腸内視鏡にて、目門縁より約 $15 \mathrm{~cm}$ 口 侧の直腸に不完全閉塞を認め、生検により中分化腺癌 と診断した。またCEAは7500と異常高值を示した。腹 部 C Tにより肝 S 5に径 $8 \mathrm{~cm}$ 大の転移性腫瘍を認め、 また胸部 X線写真では肺右葉 S 8に径 $3 \mathrm{~cm}$ 大の転移性 腫瘍を認めた。いずれも単発病変であり、若年者で全 身状態も良好であることから、直腸高位前方切除、肝 S 5 亚区域 S6部分切除、肺右葉 S 8 部分切除の同時手 術を施行した。原発巣周辺No241リンパ節および縦隔 No7、No8リンパ節に転移を認めた。術後経過は良好 で、肝動注ルートから5FU-Leucovorinによる化学療法 を2クール施行した。術後経過は良好で2力月経過した 現在、CEAの急速な正常化をみている。

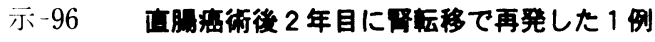
水戸中央病院外科 川本微、小野陸、仁高学

同 泌尿器科岩崎明郎

筑波大学盟床医学系病理 萰池正数

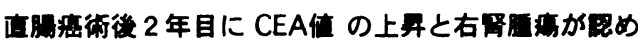

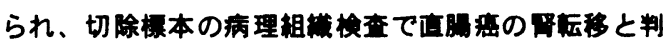

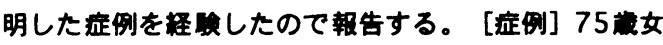

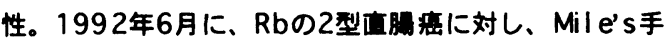

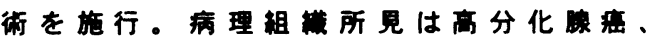
ai , $v_{1}, l y_{2},, n_{1}(+), a w(-), o w(-), e w(-)$ 。街後 2 年目に

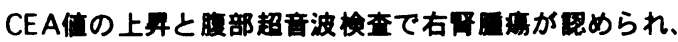

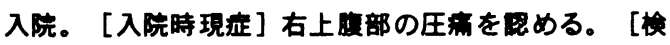

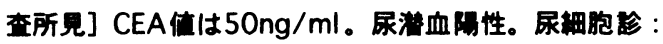

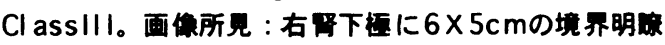

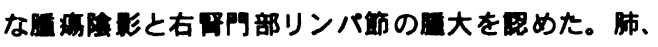
肝に枟移所胃なし。[手術所見］1994年8月手術施行。

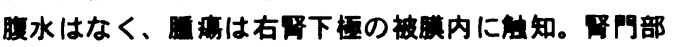

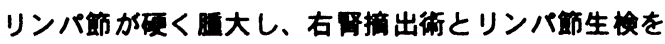

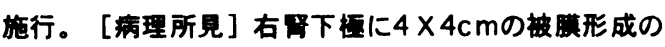

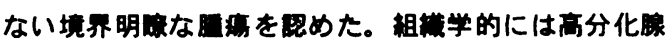

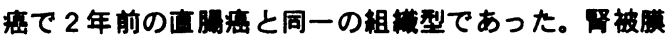

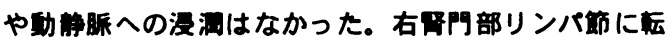

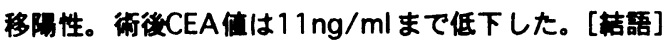

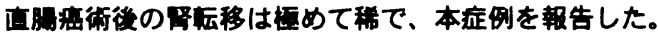




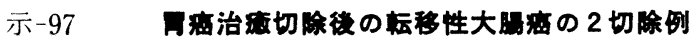

国家公称員等共済組合連合会名城病院外科 久納孝夫 土江健嗣 大島 章 西本和生 世古口英 鵜飼克行

大腸への癌の転移は少なく、転移の多くは重性腹膜炎のた め切除可能症例は少ない。最近、胃癌治庱切除後の転移性大 腸癌の 2 切除例を経験したので報告する。

【症例 1】58歳、女性。主訴は下腹部膨満感。2年8力月前、4型 胃癌にて胃全摘勝脾合併切除、 $\mathrm{D}_{2}$ 郭清施行。低分化型腺 癌、 $\mathrm{P}_{0} 、 \mathrm{H}_{0} 、 \mathrm{se} 、 \mathrm{n}_{0}$ で根治度 $\mathrm{B}$ であった。腹部 $\mathrm{X}$ 線、CTにて 右側結腸の拉張があり注腸検査で横行結腸に収束型狭窄像 を認めた。横行結腊切除、Roux-en-Y空腸切除、2個の腹膜播 種を合併切除した。術後 1 年再発死亡した。【症例 2】55歳、 男性。主訴は、腹部㵙感。4年7カ月前、胃体上部の3型胃癌 にて胃全摘脾合併切除、 $\mathrm{D}_{2}$ 郭清施行。中分化型腺癌、 $\mathrm{H}_{0}$ 、 $\mathrm{P}$ o、ss、 $\mathrm{n}_{0}$ で根治度 $\mathrm{A}$ であった。腹部 $\mathrm{X}$ 線、CTで横行結腸の 㹡張を認め、注腸検查では脾沙曲部の下行結腸に全周性の狭

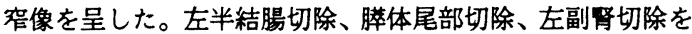
施行。術後 10 力月再発の兆候なく健在。【考察】1、再発形 式は、微少な腹膜播種ないしリンパ管内の癌串残か implantationが考えられた。2、腹部膨満感の検索時、腹部 $\mathrm{X}$ 線やCT で結腸の拡張像に注意し、注腸検查を行うことが 大切である。

示-98右半結榪食道再建例に突発した逆行性閶

重積症の 1 例

皮見市民病院外科 ${ }^{1}$ 、周渴科 ${ }^{2}$

○元文彦 ${ }^{1}$ 、吳哲彦 ${ }^{1}$ 、牧野哲也 ${ }^{1}$ 、村田修一 ${ }^{1}$ 、

清崎克美 ${ }^{1}$ 、中坪直樹 ${ }^{2}$ 、若狭林一郎 2

今回我々は、右半結渴、胸骨後経路による食道再建 術後、妁 1 年目に渴重糟症により急性腹症を呈し、開腹、 整復術を要した例を経した。さらに、空渴出出脚の 空晹一空渴一結腈伆合部というきわめて希な逆行性の重 積状態であり、術後に行った諸梌査に於いても器覓的 異常を認めず、かかる状態の発症機転が不明のため、 諸般のこ意見を同いたく症例を提示し報告する。

症例は、68藏、女性で、䄪1年前に胸部中部食道癌を 指接され、術前照射後に右開胸開腹法にて胸部食道全 摘、残胃全揞と回渴末端を含む右半結閶による食道再 建行を行い経㝵良好にて外来加瘦中であった。突然発 症した濑のため、救急車にて来院した。来院時、血 压は保たれていたものの、呼吸、腺拍は促迫し、冷汗 を伴い前ショック状態を呈していた。自発腹痛ととも

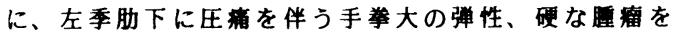
知し、直ちに行った腹部超音波像と監床所見より皎 括性閶閉塞と診断し、直ちに全身麻醉下に開腹術を施 行した。開㙏時、左季肋下に手拳大に膨した結晹を

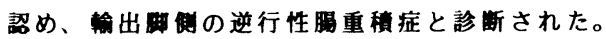

示-99重複腸管内容が興味深い所見を呈した 成人の回腸重複症の一切除例

新潟県厚生連中央綜合病院 外科 野村達也 加藤英雄, 新国恵也, 吉川時弘, 佐々木公一

消化管重複症は比較的まれな疾患であり，乳幼児期 に発見されることが多い。今回我々は成人の回腸重複 症を経験したので若干の文献的考察を加えて報告する。

患者は 61 歳, 男性。主訴は右下腹部痛。某医を受 診し, 精查の結果, 回盲部腫瘍を疑われ, 手術目的に 当科へ入院した。腹部エコー, 腹部 C T $\mathrm{T}$ て回盲部に 直径 $5 \mathrm{~cm}$ 大の軎腫を認めた。注腸造影では終末回腸か ら上行結腸にかけて内側からの压排所見を認めた。回 盲部腫瘍を疑い開腹手術を施行した。虫垂には異常な く, 終末回腸に接して腸間膜側に $5 \mathrm{~cm}$ 大の囊胞性腫瘤 を認め, 回盲部切除を行った。切除標本では終末回腸 に腫瘤による圧排を認めたが粘膜に異常はなかった。 腫瘤の内容は $20 \mathrm{ml}$ ぼの黄色桨液性の液体であり, 内容液の腫瘍マーカーはCEA 1702ng/ml,CA19-9 2369U $/ \mathrm{ml}$ 著明に高値であった。正常の腸管との交通は見ら れず, 内面は正常の腸粘膜と思われる上皮に被覆され ていた。病理学的には囊胞壁には固有筋層が存在し, その上皮はCEA染色, CA 19-9染色陽性であったが,PA $\mathrm{S}$ 染色, アルシアンブルー染色ともに陽性であり, 幼 弱な腸上皮を持った回腸重複串腫であった。

\section{示 -100 成人晹重積 7 例の経験}

茅ヶ崎徳洲会総合病院 外科

样口倫代, 椞浦多賀雄, 青木重害, 三陯博久

（目的）成人の腸重積は奻児のそれとは，原因，部位治療 方針とも異なる。別の疾患と考兄るべきであるが我々は

' 85-'94の間に 7 例の幼児以外の腸重積症を経験し, こ れを検討したので報告する。

（方法）患者リストに診断を"腸重積 "と記録されている 症例から幼児を除外し, カルテ, 手政記録, 剖検記録を reviewした。

（結果）年令は 10 オー70才まで, 男性 6 例, 女性 1 例 であった。確認診断は，手術によるもの6 例. 剖唡によるも の1例であった。

原因別では，腫瘍によるもの 4 例，（5ち 1 例が悪性）， 瘏着によるもの 2 例，医原性のもの 1 例であった。部位別に は，小腸一小腸が 3 例，小腸一大腸（回盲部）が 4 例であった。 手術を施行した 6 例中, 筑着による2 例は解除術のみを行ない, 腫 歾による 4 例は回盲部の腸重積で，回盲部切除術又は右半結腸切除術 を行なった。6 例中, 術前に腸重積と診断されていたものは 5 例であ った。

（結語）成人の腸重積は，80\%に明らかな原因を認め，部位は， 小腸と大腸がほほ半数ずつといわれている。また, 成人では, 全例, 手術による治療が原則である。今回我々の経験した 7 例中剖検例以外 で，手術を施行し，経過は良好であった。 
示-101成人腸重棈症の 3 例

市立池田病院外科、同中検病理 ${ }^{2)}$

横山茂和 ${ }^{1)}$ 下向博洋 ${ }^{1)}$, 完山裕基 ${ }^{1}$, 福島幸男 ${ }^{1)}$

奥 邦彦 ${ }^{1}$, 柴田邦隆 ${ }^{1}$, 松田泰樹 ${ }^{1)}$ 松下 豊 ${ }^{1}$

中山 賢, 大井 守 ${ }^{2}$

小児と異なり比較的稀と言われている成人腸重積症 の 3 例を経験した。症例 1 は 43歳、男性。繰り返す腸閉 塞症状があり注腸検査にて右側結腸の腸重積と診断し 開腹、回腸の脂肪腫を先進部とする回腸結腸腸重積で結 腸右半切除術を施行した。症例 2 は 62 歳、男性。多発 性肺腫瘍の経過中に腸閉塞、消化管出血出現し開腹、 肺癌の小腸転移病巣を先進部とした空腸空腸腸重積で 小腸切除術を施行した。症例 3 は 49 歳、女性。腸閉塞 症状出現し腹部 C T 検查にて右側結腸の腸重積と診断 し開腹、回腸結腸腸重積で上行結腸に癌を認め結腸右 半切除術を施行した。

成人腸重積症は比較的稀であるが小児腸重積と異な り経過が長く、器質的疾患が存在するてとがほとんど である。また、上記 3 例のような開腹歴のない腸閉塞 症例では、ほとんどに外科的処置が必要で、迅速な術 前管理、術前検查の上、病変に応じた治療が必要であ る。

\section{示-102 小腸腫瘍による成人腸重積症 3 例の検討}

群馬大学第一外科

木下照彦、内田 聡、東海林久紀、金古 康、

杉山博之、篠崎 啓、浅尾高行、小板橋宏、

竹之下誠一、長町幸雄

【症例 1】36歳、男性。Peutz-Jegers症候群。平成6年

8 月 13 日早朝より腹部膨満感、心窝部痛及び喝吐が出現。 腹部US、CT検查にて㹡張、肥厚した小腸と2個の径 $2 \mathrm{~cm}$

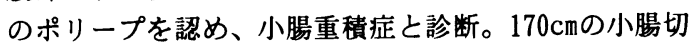
除術、5個のポリープ切除術を施行。組織学的に過誤腫。

【症例 2 】 60 歳、男性。CLL治療中。平成2年2月13日よ り突然幐周囲部痛、喝吐が出現、1時間程で轻块。2月 15日、同症状のため当科受診。右腹部巨大腫瘤を触知。 腹部US、CT検查にて腸管壁の肥厚、拡張と内部に腫瘤 を認め、小腸重積症と診断。 $80 \mathrm{~cm}$ の小腸切除術を施行。 切除標本ではパイエル板に一致する小豆大〜拇指頭大 の腫大リンパ節を認めた。病理学的に悪性リンパ腫。

【症例 3 】46歳、男性。平成2年8月下旬より右下腹部 痛が出現。9月上旬より下血を絽り返すため9月17日近 医を受診。注腸造影を施行。右半結腸の著しい短縮を 認め、当科紹介受診、入院。腹部US、CT検查にて右下 腹部に重積する腸管を認め小腸大腸型の腸重積症と診 断。回盲部切除術を施行。病理学的には脂肪腫。

【結語】術前診断には腹部US、CT検査が有用であった。
示-103 DMH誘発マウス大腸癌における䔬便中胆 汁酸の変動について

近畿大学医学部第二外科 ${ }^{11}$ ，塩野義製薬 株式会社 2 )

上田省三 ${ }^{1)}$, 中谷公一1), 今野元博 ${ }^{1)}$, 注田昭男 ${ }^{1)}$, 大柳治正 ${ }^{1)}$, 内田清久 2), 五十君裕玄 ${ }^{2)}$, 高瀬治登 ${ }^{2)}$, 野村泰治 2 )

目的：DMH誘発大腸癌について無菌動物は普通動 物に比較して発癌率が低く，また外因性胆汁酸投与 によりpromotionを受けることが知られている。そこ でDMH発㿋における内因性胆汁酸の関与を調べるた め, 普通マウスの便中胆汁酸を測定した。

方法：ICRマウスにDMH $30 \mathrm{mg} / \mathrm{kg}$ を20週投与し, 便中胆汁酸をガスクロマトクララフィーで測定した。 結果：鿓便1gあたりの総胆汁酸排泄量はDMH群で非 投与群の約 $1 / 4$ で, deoxycholic acidは1/7, chenodeoxycholic acidは検出されず, lithocholic acidは1/5， cholic acidは1/2であった。

考察：DMH投与による便中総胆汁酸量や発癌 promotorとされてきた胆汁酸の隇少から，マウス DMH発癌においては, 内因性胆汁酸による promotion作用は強いものではなく，むしろDMH自 身がより強力な発癌物質に変換されることが発癌の 本態であると考えられた。

示-104 DMH 誘発ラット大晹腫䓪における Spermidine / spermine $\mathrm{N}^{1}$-acetyltrans ferase活性の意義 大阪市立大学第一外科, 第二生化学 ${ }^{1)}$, 大阪市立粉 合医療センター外科 ${ }^{2}$

繁澤 晃, 鄭容錫, 中西一夫, 佐藤成, 仲田文造, 西口幸雄, 池原照幸, 奥野匡有 ${ }^{2}$ ， 大谷周造 ${ }^{1)}$, 兽 和融生

〔目的〕ODC同様ポリアミン代謝に関わる酳素で, その分解系の律速酝素であるSATについて1,2Dimethylhydrazine（以下DMH）誘発ラット大腸癌モ デルを用い，大腸腫清発生でのSATの意義をODCとと もに経時的に測定し検討した. 〔方法〕Sprague-

Dawley系雄性ラットを用いDMH $20 \mathrm{mg} / \mathrm{kg} /$ weekを連続 20 回, 背部の皮下に注射した. 投与開始後 5 週，10週， 15週，20週，25週，30週目に屠殺し近位大腸，遠位 大腸の肉眼的正常部を採取し各々SAT活性, ODC活性 を測定した。〔成䋶および結論〕腫场発生は近位で20 週より，遠位では25週よりみられた。SAT活性は投与 群で高值を示す傾向であり，近位では20週より，遠位 では25週より有意に高値を示し, 腫㘯発生時期と一致 した，ODC活性は投与群で高値を示す傾向であった。 このDMH 誘発ラット大腸㿋モデルにおいて腫場発生 にODC活性が高值を示す状態においてS AT活性の上昇 が重要な役割を果たしている可能性が示唆された。 
示-105 Azoxymethane誘発大腸腫瘍に対するアッ プルペクチンの抑制効果 (第2 報) 一蔂便中短鎖脂肪 酸拄よび腸内細菌丵からみた考察—

富山医科薬科大学第二外科、同薬学部衛生化学* 大上英夫、田沢賢次、山下篇、坂本隆、山下 芳朗、唐木芳昭、村井健二*、小橋恭一* 、藤巻雅夫

【目的】第43回本学会で、水溶性食物織維である アップルペクチンが、Azoxymethane（以下AOM）誘 発大腸発癌に対し抑制効果を示したことを報告した。 今回、 2 種類のペクチン [アップル (以下AP) およ びシトラスペクチン（以下CP）] を用い、AOM誘発 大腸発癌に対する効果を、䔬便中短鎖脂肪酸（盲腸 内）および腸内細菌丵の面から検討した。【結果、 考察】対照群に対してAP群において有意な腫演誘発 抑制、および腫瘍数の減少が認められた。水溶性食 物織維は腸内細菌により発酵を受け、筫便中短鎖脂 肪酸量が増加し大腸癌の発生や增殖を促進すると言 われている。今回、ペクチンにより短鎖脂肪酸棇量 は変化せず、大腸癌抑制との関与は明らかではなか った。腸内細菌叢は両ぺクチン群ともL Lactobacillus、 Bifid obacteriumが増加傾向にあったが、アップルペク チンに特異的ではなかった。短鎖脂肪酸との関連も 含めて、アップルペクチンの腸内細菌に対する影響 は、今後さらなる検討が必要と思われた。

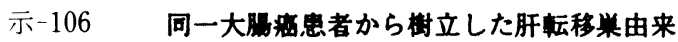
腹膜播種性㡖移学由来の細胞株の性状の䢖いについて 秋田大学第一外科

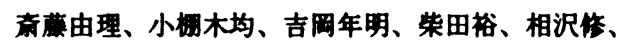
小山研二

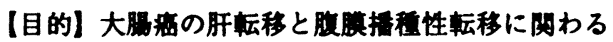

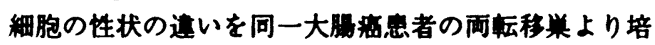

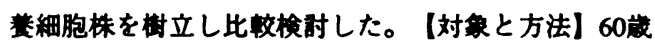

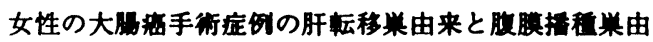

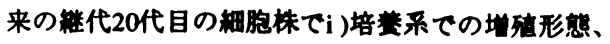

ii)電影像、ii)渞殖速度、iv)ヌードマウス皮下可桔性、 v)フローサイトメトリーによる絧胞表面执原(CEA、 シアリルLeりの発現を比較した。【結果】i)培荃系での 增殖形㮩: 肝伝移栄由来細胞株は接首性の强い多角形 の細胞が島状に、胶渞括程性轱移紧由来細胞株では接 着性の弱い類円形の細胞が培菜面に均一に增殖した。 ii)奄影像：肝転移紧由来細胞株に分泌頪粒がより多かっ た。iii)增殖速度iv)ヌードマウス皮下への可植性は差は なかった。 v XCEA 発現は肝枟移紧由来細胞株でより强 く、シアリルじ発現は両株ともなかった。【まとめ】

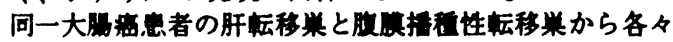

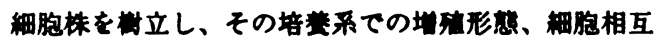

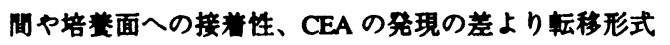
に接首因子が井与していると考えられた。
示 -107 ラミニンを用いた大腸癌肺転移巣基底膜

の検討

近幾大学医学部第一外科

大塚浩史，久保隆一，待寺則和，喜多岡雅典 進藤勝久，安富正幸

[目的］基底膜を形成する大腸癌が高率に肝転移をき たすことより，肝転移に基底膜が重要な役割を果たして いることが明らかになってきた。一方、肺転移に関して の詳細な検討はほとんどなされていない。 そこで，肺転 移巣の基底膜を免疫組織学的に検討し，大腸癌基底膜と 肺転移との関係について検討することを目的とした。

[対象・方法] 転移巣が手術的に切除され, 原発巣と の比較検討が可能であつた24例を，ABC法による Laminin (LN)染色で検討した。 また対象を肝転移合併症 例(7例) と単独肺転移症例(17例)に分けて検討した.

[結果・考察] 肝転移合併例では，原発巣基底膜形成 癌4例中4例( 100\%)が，非形成癌3例中2例(66.7\%)が肺転 移巣において基底膜を形成していた。一方, 単独肺転移 例では，原発巣基底膜形成癌8例中7例(87.5\%)が肺転移 巣で基底膜を形成していたが、非形成癌9例中転移巣で 基底膜を形成していたのは2例(22.2\%)のみであつた。

転移経路として経門脈的と考えられる肝転移合併例で は，原発栄基底膜形成癌のみならず非形成癌でも肺転移 巣で基底膜を形成しており、基底膜がその転移形成に強 <関係していると考えられた。一方, 単独肺転移例では 原発巣と肺転移巣での基底膜形成の有無はよく相関し， 癌基底膜の検索は大腸癌単独肺転移機構の検討に有用で あると考えられた.

示-108直腸癌の前方切除術における手縫い吻合 法と器械吻合法との比較検討 京都府立医科大学第 1 外科

下間正隆、市川大輔、大辻英吾、北村和也、谷口弘毅、 萩原明於、山根哲郎、山口俊晴、沢井清司、高橋俊雄 【目的】直腸煰前方切除術の際の手释い吻合と器械吻 合の合併症について検討したので報告する。

【刘象と結果】当科で前方切除術を施行した60例を 対象とし、吻合の種類による合併症を比較検討した。 (1)吻合法は層首吻合による手縫い吻合 34 例、自動器 械吻合器のみによる器械吻合 19 例, Double Stapling Techn ique法 7例であった。手縫い吻合のうち2 例 (7.7\%) は自動器械吻合失敗からの変更例であった。 (2)縫合不全は手縫い吻合 5 例 $(14.7 \%)$ 、自動器械吻合 器のみによる器械吻合 1 例 (5.3\%)に発生した。

(3)吻合部狭窄症状は自動器械吻合器のみによる吻合 2 例（Rs 1 例、Ra 1例）（10.5\%）に発生したが、経 肛門的バルーン拡張術にて改善した。

【考察】手縫い吻合法に比べて器械吻合法での縫合不 全の発生率は低かったが、自動吻合器のみによる器械 吻合法で吻合部の軽度の狭窄症状が出現した。器械吻 合は簡単で迅速であるが、手技に失敗したときの修復 のためには、手縫い吻合法を修得しておく必要がある と思われた。 
示-109 大鹗実験溃渴モデルにおける粘膜筋板再生 治庶過程の形態および生化学的篗察

産業医科大学第一外科

岡崎啓介、永田直幹、平田敬治、原一生、伊藤英明 創傷治癒における直腸粘膜筋板再生治癒過程に関与し ている、多潜能性線維芽細胞群 $(\mathrm{MFb})$ の動態ならびに既 存平滑筋細胞の有系分裂增殖による再生への関与の有無 について観察を行うとともに、創傷治獑に関与する $\mathrm{MFb}$ のフィブロネクチン $(\mathrm{FN}) 、 I \cdot I I I$ 型コラーゲンの産生と 放出について、生化学的および免疫組織化学で検討し、

さらにBromodeoxy uridine (BrdU)を用いてその細胞動態 を観察した。

成熟雄家鬼の直腸粘膜に直腸鏡で実験的潰場を形成 し、経時的に摘出した。光顕試料はホルマリン固定・パ ラフィン包埋、電顕試料はKarnovskyとOsmic酸の二重 固定、エポン包埋した。免疫組織化学は光顕切片をBSA 標識免疫染色を行った。なお屠殺 1 時間前に $\operatorname{BrdU}(50 \mathrm{mg} / \mathrm{kg})$ を腹腔内へ投与後BrdU染色を行った。

創傷治猲過程における平滑筋組織の再生について $\mathrm{MFb}$ の重要性が示唆され、またFN、I・III型コラーゲン、 BrdU染色の陽性反応がそれらの細胞群に認められ、ま た生化学的にも創傷早期より mRNAレベルの上界がみら れた。今回の観察結果は既存の粘膜筋板平滑筋組織から 再生が起こるのではなく、MFbが創傷早期より FNやI · III型コラーゲンを産生放出し、平滑筋細胞へ分化し、平 滑筋組織を再生していることを示唆する。

示-110 大腸手術の術前処置としての Bowel Preparationが患者の水・電解䓄バランスに及ほす影䨘 関西医科大学 第 2 外科

高田秀穂、岩本慈能、越路みのり、吉田 良、 中川州幸、森田美佳、川西 洋、吉岡和彦、日置紘士郎

〔目的〕Bowel Preparationが患者の水・電解質バラ ンスにいかなる影響を及ぼすかについて検討した。 【方法】腸管に完全閉塞のない待機大腸手術患者 35 例 に Picolax $^{\circledast}$ (10mg sodium picosulphate $/ 13 \mathrm{~g}$ magnesium citrate) を用いる Bowel Preparation を行った。Picolax ${ }^{\circledast} は 2$ 回投与を行い、患者には充分

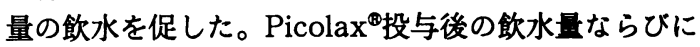
排泄した䔬便および尿量を測定して水分バランスを計 測し、さらに排泄された鿓便ならびに尿中の電解質䨿 失量を計測した。また Bowel Preparation 前後に採 血を行い、血清電解質、 $\mathrm{Hb}, \mathrm{Ht}$ ならびに酸塩基平衡の 変化についても検討した。

[結果] Bowel Preparationによって大量の水・電解 質の衰失があったが、ほとんどの症例において血液検 查上の変化は軽微であった。

[結語] Bowel Preparationによって大量の水・電解質 が寝失するが充分量の飲水によって、多くの場合に生 体はホメオステイシスを保ちうるが、老人や循㻴器系 に障害のある場合は注意を要する。
示-111大腸癌術前处置の比較検討 - T PN法と Polyethylen glycol電解質液法との比較

鳥取大学第一外科

牧野正人, 久光和則, 菅村健二, 中村誠一, 倉吉和夫, 木村 修, 貝原信明

大腸術前処置として Polyethylen glycol電解質液法（PG 法）と, TPN法とを腸管内清浄度，腸内細菌数の面か ら比較検討した。（対象・方法）TPN群（n=6）では， 術前 1 週間絶食，水分のみでTPNを行い，手術前日に マグコロール p 1 袋，プルセニド2錠を投与し，手術当 日はグリセリン浣腸を行った。 PG 群 $(n=8)$ では, 手 術前々日プルセニド2錠，手術前日にPG液を $2 \mathrm{~L}$ 服用さ せた. 3例ずつで直腸洗浄液内の細菌数を測定した。

(結果) 平均排便回数はTPN群で6回, PG群で10回, 平均排便所要時間はTPN群で4時間, PG群で7時間と PG群で回数が多く時間も長かった。PG群での飲用所 要時間は平均 3 時間30分であった。腸管の清净度は, TPN群の1例を除いて良好であった，直腸洗浄液の細菌 学的検査ではTPN群では絵菌数平均 $4.1 \times 10^{5}$ 個/mlであ ったのに対して, PG 群では $3.4 \times 10^{3}$ 個 $/ \mathrm{ml}$ と細菌数が少 なかった。（まとめ）PG法はTPN法に勝るとも劣らぬ 腸管内の清浄化が得られ，QOLの面からも有用な大腸 前処置法の一つである.

示-112 大腸癌手術における術前腸管処置法と術 後感染

滋賀医科大学第 1 外科

遠藤善裕、谷 徹、田畑貴久、花澤一芳、小玉正智 (目的)大腸手術に際し、術前腸管処置は、術中術後 経過に関連すると考えられる。機械的前処置として、 Niflecが従来法に変わり用いられることが多くなった か、術前腸管処置方法と術中の腸管清浄度、術後創感 染との関連につき検討した。（対象,方法)平成4年よ り平成6年5月末までの大腸癌手術83例につきNiflecを 用いた群(Niflec群 $n=33$ ) と他の下剂によった群(非 Niflec 群 $n=39$ )と下剤を全く投与しなかった群(無下 斉群 $n=11$ )に分け検討した。（結果）1)腸管清浄度 良の創感染率は2/58で、清浄度不良では5/19で、腸管 清浄度と創感染には相関を認めた。 2)前処置法と腸 管清净度: Nif l ec群(良:不良=30:1)、非Niflec群(良： 不良=23:13)、無下剤群 (良: 不良=5:5)で、Niflec群 は、腸管清浄度が良好であった。3)前処置と術後創 感染:Niflec群(33例全例が感染なし)、非Niflec群(感 染有:無=7:32）、無下剤群では、（感染有:無=1:10） で、Niflec群は、術後創感染が少なかった。（結論） 腸管清浄度と、術後創感染には関連がみら、Niflecを 用いた術前腸管処㯰は手術時の腸管清浄度に優れ、術 後創感染が有意に減少した。 
示-113 大腸癌同時性肝転移に対する間欠的動注 療法の検討

国立金沢病院外科,同放射線科 1 )

竹川茂,松本尚,小島靖彦, 木下睦之,道場昭太郎, 浅井伴衛,津田宏信,小林昭彦1)

【目的】過去10年間に経験した大腸癌肝転移症例を対 象に、皮下埋め込み式動注リザーバーを用いた間久的 動注療法を試みてきたのでその効果について報告する。 【対象と方法】1984年1月から1993年12月に当科で経 験した大腸癌症例は結腸癌259例、直腸癌 138例、計 397 例であり、うち結腸癌35例、直腸癌 13例、計48例 (12.1\%)に同時性肝転移を認めた。このうち他䑏器重 複癌を有する5例を除く43例について、肝転移程度別 に動注療法群と抗癌剂の全身投与群との間で奏効率、 術後生存期間を比較検討した。

【結果】 H 2,3症例32例中15例に対し術後間欠的動注 療法が行われ（動注療法群）、17例に対しフッ化ピリ ミジン系薬剂の全身投与のみが行われた(全身化療群)。 有効例は動注撩法群では 2 例認められたが、全身化療 群では 1 例も認められなかった。予後に関しては、動 注療法群では、全身化療群に比し有意に良好であった （一般化ウィルコクソン検定、 $\mathrm{p}<0.05$ )。

【結語】肝転移以外の非治瘾因子が存在しない症例で は、間欠的動注療法が有効であると思われた。

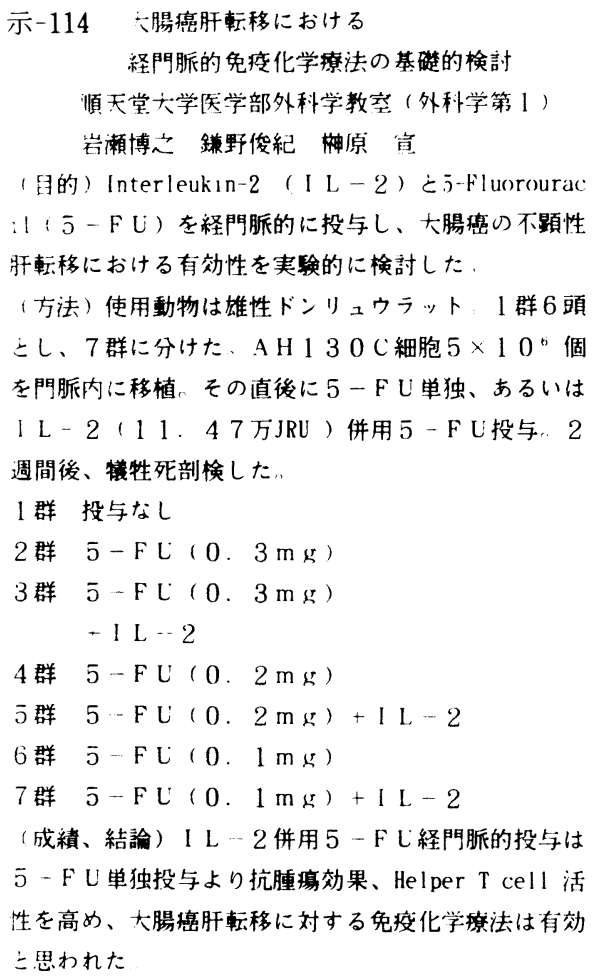

示-115肝動注カテーテル留置中の合併症に関する 検討

防衛医科大学校第一外科

山本哲久，別宮慎也，望月英隆，中村栄秀， 初瀨一夫, 吉村一克, 横山幸生, 玉熊正悦

【目的】肝動注療法の中止原因となるカテーテルト ラフルルについて検討する.【対象】大腸癌肝転移症例の うち皮下埋め込み式カテーテルを留置し肝動注療法を 行った43例を対象とした.肝切除後の残肝再発予防が 20例, 切除不能転移巣に対する治療が23例であった.

【結果】(1)動脈の閉塞やカテ先の逸脱等, 器質的問題 の為，動注を中止した例は21例 $(48.8 \%)$ で，閉塞が14例 と最も多く, 次いで逸脱が6例あった. (2)逸脱先は, 肝 動脈以外の血管が4例, 十二指腸内腔が1例, 総胆管内 が1例であった.症状は，十二指腸への逸脱例が叶血を， 総胆管内例と血管内3例が背部痛や心窩部痛を呈したが， 残り1例は無症状であり，検診で指摘された胃潰瘍を契 機に逸脱が判明した。 (3)閉塞カテーテルの開存期間は 平均226日（30-632日）で，左鎖骨下動脈と胃十二指腸動 脈の2挿入法の間に差を認めなかった.【結語】1:肝動 注留置カテーテルの約半数に動脈閉塞等のトラブルが 発生した. 2: 背部痛や心窝部痛発生時は勿論のこと, 無症状であっても定期的にカテーテル造影を実施して トラフルを早期に回避する必要があると考えられた。

\section{示-116 大腸多発癌の検討}

国立舆病院外科

中室誠、濱路政靖、盤井成光、金鏞国、船津俊宏、 水島恒和、北川透、中場寛行、越知昭博

[目的］大腸内視鏡診断の普及と大腸癌の治療成績の 向上により、同時性ならびに異時性多発癌を経験する 機会が増加している。［対象および方法］1969年から 1994年 7 月までの25年間に経験した大腸癌手術症例 1201例の内で多発癌症例を検討した。第一癌と第二癌 の発現間隔が 1 年以上を異時性とした。 [結果] (1)大 腸多発癌の頻度は、全手術症例1201例中70例(5.8\%)、同 時性は41例(3.4\%)、異時性は31例 $(2.6 \%)$ 、同時性かつ異 時性は2例(0.2\%)であった。(2)多発癌70例に対する73回 の手術を年代順にならへて、大腸癌手術全体に占める 比率の增加をみると、'70年代までは2.5\%、'80年代には $5.3 \% 、 190$ 年代は $10.3 \%$ であった。(3)大腸多発癌症例の 手術時平均年㱓は、異時性第一癌のそれのみ、単発大 腸癌のそれより有意に若年であった。(4)術前診断率に つい: : 同時性多発大腸癌の術前診断率は70.4\%であっ た。異時性における第二癌発見の動機で定期的な検診 の占める割合は $13.6 \%$ 、異時性第一癌から第二癌までの 間隔は平均 7 年 3 力月であった。(5)累積生存率の比較 : 京時性、異時性、および単発癌の間には有意差が認め られなかった。 
示-117同時性大腸多発癌症例の検討

長崎市立市民病院外科

池松禎人、天野実、兒井和裕、北島知夫、

蒲原行雄、井上啓爾、前田潤平、中田剛弘、宮田昭海、

森 英昭

（目的）同時性大腸多発癌症例の臨床病理学的な検

討を行う。

（方法）過去8年8カ月間に当施設で手術した大腸 癌342例中、同時性多発癌 10例 (3\%) )対象とした。

(結果) 男女比 1.5:1。平均年齡65歳。有症状 8 例、 健診発見2例。主病巣の局在部位は右側結腸 2 例、左 側結腸 5 例、直腸 3 例。病理組織診は高分化 -中分化 腺癌各5例。全例に根治的な切除術を施行した。副病 巣は2症例で3重複癌のため計12病変。局在部位は主 病巣と同側 10 病変（83\%、直腸を左側に含む）、対 側 2 病変 $(17 \%)$ 。病理組織型は主病巣と同じもの10病 变 $(83 \%)$ 、異なるもの2病変 $(17 \%)$ であった。術後は2 年4 カ月目に癌死した1例を除き、全例生存中である。

(考案) 同時性大腸多発癌は同一機序、または管腔 内播種により発生した可能性があり、存在を念頭にお き検査を行うことが重要である

示-118直腸中分化型腺癌の臨床病理学的特徵と治 療成績に関する検討

富山市民病院外科 角谷直孝広野禎介 小西一朗 上田順彦 黒阪慶幸 太田長義 吉光 裕 根塚秀昭 同病理 高柳尹立

(目的) 直腸中分化型腺瘦の臨床病理学的特徵と治療 成績について検討し、外科治療上の問題点を明らかに する。(対象) 当科で手術された直腸跑299例を対象と した。直腸癌の部位別内訳は、Rs77例、Ra81例、Rb 137例、P4例であった。組織型別内訳は、高分化型84 例(31\%)、中分化型167例(61.6\%)、低分化型10例(3.7\%)、 粘液癌10例(3.7\%)その他、不明28例であった。

(結果) 直腸中分化型腺癌は高分化型に比べ壁深達度、 リンパ節転移、脈管侵售の高度な例が多く、肝転移や 腹膜播種の頻度も高い。根治度A症例の部位別 5 年生存 率も中分化型は高分化型に比べ有意に不良であった。 ただし、stage3 aまでの同一stage内では高分化型と中分 化型の5年生存率に差を認めず、 stage3 b症例の大部分 が中分化型であること、stage3 b症例の生存率の不良さ が両者の生存率の差となっていた。中分化型直腸疾の 治療成績向上にはstage3 b (n2,3症例) の治療をいかに 行うかが重要である。
示-119 イレウス症状を呈した大腸㿋症例の臨床 病理学的検討

豊橋市民病院外科

本野泰司, 鈴木一男, 千木良晴ひこ，加藤岳人 柴田佳久, 栗野 浩, 岡本好史, 鬼頭 靖 関 知子, 吉田克同, 神谷 諭, 平松聖史 安部哲也

【目的】イレウス症状を呈した大腸癌症例の䂏床病理 学的特幑について検討した。

【対象及び方法】1989年 1月〜1994年 7 月に当院で行 われた大腸癌手術症例 506例中イレウス症状を呈した 症例（イレウス群）50例 (9.8\%)を対象とし, イレウス 症状を呈さなかった症例（非イレウス群）456例と偟 床病理学的に比較検討した。

【結果】性比, 年齡は両群間で差は認めなかった。イ レウス群は, 非イレウス群に比べ以下の特徽を認めた. (1)横行結腸, S 状結腸に多い. (2)肉眼的には 3 型で全 周性が多い。(3)組織学的には深達度, リンパ節転移, リンパ管侵襲が高度でstageVが多い，(4)切除率, 治 瘏切除率は低いが, stage II 以上の治瘡切除例では生 存率に有意差は認めない.

【結語】イレウス症状を呈する大腸癌は高度進行例が 多いが，治瘜切除できればイレウス症状を呈さない大 腸癌とほほ同じ予後が期待できる.

\section{示-120直腸 $\mathrm{m} \mathrm{p}$ 我手術症例の検討}

大阪府立病院消化器一般外科 ${ }^{1 !}$, 同病理 ${ }^{2 \text { ? }}$

本多正治 ${ }^{1}$ ，井上善文 ${ }^{1)}$, 田中康博 ${ }^{1)}$, 伏見博彰 ${ }^{2}$ 高尾哲人"

【目的】固有㬳層における壁深達度と再発との関連 を明らかにするために直渴 $\mathrm{mp}$ 癌の臨床病理学的特幑を 検討した。【対象】1981年から1992年までに、治切除 手術を施行し、1年以上の経過観察が可能であった直腸 $\mathrm{mp}$ 癌30症例を対象とした。【方法】固有筋層を3等分し、 浅層より mp1群 (14例) - mp2群 (11例) - mp3群 (5例)に分類 した。再発はmp2群3例とmp3群2例の5例に認められた。 そこで対象症例を、mp1群とmp2+3群の2つに再分類し、 術前CEA值・腫疸最大径·肉眼分類·組穖型・リンパ管侵 襲·静脈侵裝・リンパ節転移について比較し、再発に関 連する因子について検討した。【結果】リンパ管侵襲 と再発率は、mp2+3群において有意に高率であった。他 の項目には有意差を認めなかった。再発形式は肝転移 1例、局所再発4例(会陰再発2例、仙骨前面再発2例)であ った。この4例はいずれもリンパ節再発と考えられた。

【結語】直腸 $\mathrm{mp}$ 癌症例において $\mathrm{mp} 2+3$ 群症例はmp 1群症 例より再発动が有意に高率であった。mp2+3群において は、リンパ管侵熟が高慗に見られることにより遭残リン パ節における micro metastasis が高率に起こっており、 このことが再発に関与している可能性が考えられる 


\section{示-121肛囲Paget病を伴う亩䐦瘦の1例 市立宇和岛病院 外科}

本田五郎、八木草彦、上原微也、藤山求二、坂尾着彦、 岡上量猛、梶原伸介、山绮信保、木下研一

【症 例】83蝔、男性。平成6年6月27日、肛門出血 を主訴に当科受診し、肛門周囲の径的 $2 \mathrm{~cm}$ の瘦痕状病 変と共に肛門管内の7時の方向に内痔核とその奥にポ リープ様の硬い缰瘤を認めた。生梌にて肛門管内病变 はgroup5、肘門周囲病变はPaget病の款断を得た。 【手 術】平成6年7月13日、囬肠切断術を施行した。 【病 理】(1)肛門管内病変：well differentiated adenocarcinoma (Rectal type) sm INF $\beta>\alpha$ ly0 v0 ow(-) aw(-) n(-) (2) 肛門周囲皮应病变 : Paget's disease (carcinoma in situ)

【考察】肛囲Paget 病ではPaget 細胞は印㺺細胞 样であり大脗に多い杯細胞に類似することが指摘され ている。しかし亩嵒瘦との正接的な関係は明らかにさ れていない。その病型も監床的な分類として(1)肛囲限 局表在型、(2)汗管または汗腺癌を伴う肛囲限局表在型、 (3)亩渴.肛門癌を伴うものに分類され、(3)は更に亩腸 原発型、肛門周囲（Paget 病）原発型、亘椱型に分 類されるにとどまる。しかし肛囲P aget 病は亩膈瘦 を高率に合併することには変わりなく、臨床的には十 分な注意を要する。

示-122横行結腸に発生した腺扁平上皮密の一例 京都府立与謝の海病院外科

閑啓太郎, 内藤和世, 鶴田淳, 大森浩二, 鈴木茂敏, 大森吉弘, 岡隆宏

大腸に原発する悪性腫㥁は肛門，直晹下部を除くと ほとんどが腺嵒であり腺扁平上皮息の発生頻度は非常 に稀とされている。今可、我々は横行結腸原發の腺扁 平上皮密の一例を経験したので若干の文献的考察を加 えて報告する。症例は70歳女性。全身僚息感を主訴に 来院。注腸検查、大腸内視鏡検查にて肝弯曲部より肛

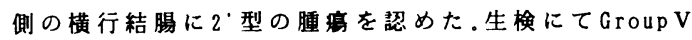
(poorly differentiated adenocarcinoma)が証明され た。手術はR3 リンパ節郭清を伴う右半結腸切除術を施 行した。腫㾇は大きさ $14 \times 6.5 \mathrm{~cm}$ 、全周性の2 型の虚で あり、組辕学的には扁平上皮虫成分がほとんどであり 一部腺管形成を呈する腺密成分が混在する腺扁平上皮 臭と部断された。リンパ節はN0.221および222が晹性で あった。\{s, n2 (+), PO, HO, M(-), stageIV\}。大腸の腺扁 平上皮密は全大腸密の0.1-0.5\%とされており、本邦で ち60例あまりの報告例をみるにすきない。右側結腸に 発生が多い傾向があり進行密がはとんどである。その 組織発生については現在のところ腺密の扁平上皮化生 説が最も有力とされている。
示-123手術侵襲による血中 IL-6・IL-8・IL-1ra・ G-CSF澧度の変動

大阪大学第二外科 1）・和歌山医大第二病理 2)

村田厚夫, 登田仁史, 田中伸生, 加藤健志, 林田博人 1), 松浦成昭 2 )

【目的】我々はこれまでサイトカインと活性化好中球が 術後合併症や多臟器不全に涑く関与していること、手術 侵襲によって炎症性サイトカインの一つであるIL-6が誘 導され手術侵襲度と強く相関し、術後合併症発症とも関 係していることを明らかにしている。今回はIL-6以外に IL-8・G-CSF更に抗炎症性サイトカインであるIL-1raの 術後血中浱度変動について IL-6 と比較検討を行った。 【方法】胸部食道癌患者・大腸癌患者で根治手術を受け た症例を対象に術後経時的に血中IL-6 - IL-8 - IL-1ra・ G-CSFをEIA法で測定した。【結果】す心゙ての血中サイト カインは術中から上昇し始め、術直後に一過性のピーク を示した。またそれぞれの変動のパターンはほぼ同様の 経過をとった。比較的手術侵襲の小さいと考えられる大 腸癌手術例の術後最大値は胸部食道癌根治術例の最大值 の約 $1 / 4$ であった。術後㫶下性肺炎からARDSに陷った 食道癌手術症例では IL-8・IL-1ra・G-CSFの上昇度は低 かった。【結論】手術侵襲により血中IL-8・IL-1ra・GCSFはIL-6と同様に上昇し、生体反応としてのサイトカ インネットワーク誘導が起こっていることが示唆された。

示-124 サイトカインレベルからみた手術侵襲の 評価とその対策

岐皋大学第 2 外科

杉山保幸、佐治重豆、国枝克行、山田城 [目的]サイトカインレベルでの手術侵襲程度の評価を 試み，手術に伴弓生体防御能低下の対策を娭討した。 [万法と結果]1)因瘦手術後に末梢血単核球のIL-6道伝 子の発現が消失または減弱する症例がみられたが、そ の動向之手術優熟の程度・病期との間に関連は認めら

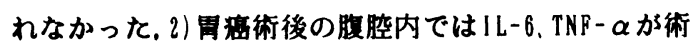
後6時間目で取高值を示し、以後渐減した。一方、成腹時 にBRMを投与すると抗腫物性サイトカイン(TNF-a、INF-

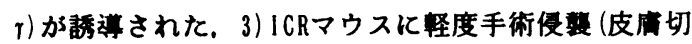

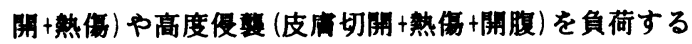
之、血消中 IL-6湠度は術後6時间以内に有意に增加し、 24 時間後に処而前值に回得したが, IL-6湌度のピーク值

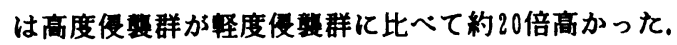
4)手術传襲負荷前のPSK経口投与により 処亚後のIL-6 湌度の上䄯は抑制され、特に高度侵熟群ではその程度 が顕著であった。 [結語]手術優意程度の評価の指标之 して血清中IL-6筫度は有用である。また、周術期のBRM 投与が高度手術侵襲によるサイトカインの過制産生を 制御したり抗腫場性サイトカインを誘迹して、担癌生 体に有利な免疫応答を惹起する可能性が推察された。 
示-125手術侵襲による炎症性サイトカインの変 動とその制御 一特にIL-6の㡅動とステロイドの効果 山形大学第一外科

久津 裕, 石山秀一, 塚本 長

【目的】侵襲に際して鋭敏に反応するIL-6に着目し， 肝切除症例を中心に周術期の血清IL-6の変動および遇 剩生体反応制御の可能性を検討した。【対象・方法】 肝切除 31 例, 非肝切除25例を対象に周術期の血清IL-6 をELISA法にて測定した。非硬変肝切除例に対し, 術 前にmethylpredonis olone $250 \mathrm{mg}$ を投与( $S$ 群: $n=6) L$, 非投与群( C 群: $n=7$ ) とで術後のIL-6值を比較, 合併症 発生との関係等を検討した。【成績】血清IL-6は術後 早期にビークをもつ一峰性の変動を示し，ビーク值は 術中出血量と相関を示した。対象56例中術後合併症発 症は22例でそのIL-6ピーク值は非発症例に比し有意に 高かった(686士214 vs $175 \pm 208 \mathrm{pg} / \mathrm{ml}, \mathrm{p}<0.001)$ 。S 群 のIL-6ピーク値はC 群に比べ有意に抑制されていた ( $159 \pm 214$ vs $691 \pm 515 \mathrm{pg} / \mathrm{ml}, \mathrm{p}=0.026)$ 。術後合併症の 発症は $\mathrm{S}$ 群 2 例(33.3\%), C 群 5 例(77.4\%)であった。 S 群ではRespiratory Indexが低值を維持し, 術後GOT, GPTの上昇が抑えられる傾向がみられた。【結語】周 術期の血清IL-6值のモニターは生体反応の大きさを把 握し合併症の予知に有用である。ステロイド術前投与 による過剩生体反応制御の可能性が示唆された。

亦-126各種手術侵襲下における血中サイトカイン の変動と周術期ステロイド投与の影響

広島大学第 1 外科 ${ }^{1)}$, 同総合診療部 ${ }^{2)}$

村上義昭 ${ }^{1)}$, 横山 隆 ${ }^{2)}$, 今村祐司 ${ }^{1)}$, 児玉 節 ${ }^{1)}$, 竹末芳生 ${ }^{1)}$, 松浦雄一郎 ${ }^{11}$

[目的］各種手術侵襲下における血中サイトカイン の変動と周術期におけるステロイド投与が血中サイトカ インの動態におよほす影響について検討した。

[方法］食道癌、胃癌、結腸直腸癌、潰瘍性大腸炎 （ステロイドカバー施行）において、術前、術後経時的 に血中 G-CSF · IL-6 - IL-8值、末梢血好中球数を測定し、 臓器障害との関連について検討した。

[結果] 食道癌術後では、他の症例に比べ術後早期 より血中G-CSF、IL-8值の著明な高値が認められ、肺、 肝などの臓器障害が高率に認められた。ステロイドを投 与した潰瘍性大腸炎症例では、血中G-CSF - IL-6は、他 の症例に比べ低值を推移する傾向にあった。

[結語］食道癌術後では、著明な血中サイトカイン の高值が認められ、それにより活性化された好中球によ り臓器障害が発症すると考えられた。また、周術期のス テロイドの投与により、血中へのサイトカインの放出は 抑制されることより、過大な手術侵歳下におけるステロ イドの術前よりの投与は、術後の高サイトカイン血症を 防止しうる可能性が示唆された。
示 -127 超高齢者の術後合併症・外科侵褩反応と その管理

神戸大学第一外科

宇佐美真、笠原宏、小谷稖治、磯篤典、阪田和哉、 平井昭博、曹遠明、孫凱、太田恭介、金丸太一、

山本正博、斎藤洋一

【はじめに】超高柃者の術後合併症の実態と動物モ デルでその病態を検討した。【対象および方法】1982 年から92年までに教室及び関連施設で手術を施行した 65歳以上85歳未満（高齢群）の消化管、肝胆膵癌及び 胆石症3052例と85歳以上の86例（超高齢群）の術前後 合併症の頻度を比較した。また、高齢ラットを用い、 LPS投与後のmediator分泌との関連を検討した。【結 果】超高齢群の疾患分布は、胃癌、大腸癌、直腸癌、 肝胆膵癌、胆石症が、38、30、11、2、5例で、食道癌 はなかった。術前合併症は、肺、心、堅、糖尿病が多 く、また、術後合併症例は46/35で、不整脈23/9、心不 全10/3、肺炎17/7、腎障害17/9、多䑏器不全 $12 / 4 \%$ が多 かった。 $(p<0.01)$ 。また、高澮ラットでは、生存率が 低く、血中PGI $2 / \mathrm{TxA}_{2}$ 比は高値で、M $\phi$ blocker投与 で生存率が改善し $(\mathrm{p}<0.01)$ 、侵裴下反応の加踰に伴う 変化が示された。【まとめ】超高齢者は、若年と異なっ た侵襲反応を示すことから、病態に応じた慎重な術前 後管理が必要である。

示-128手術侵㜔に対する生体反応における高齢者 の特異性一サイトカイン、急性相反応物留、好中球工 ラスターゼーの変動からー

熊本大学第2外科、・国立熊本病院

別府 透、小川道雄、池井 聰、片㴊茂、江上寞

【目的】外科手術前後の血中サイトカイン、急性相 反応物筫、好中球エラスターゼの変動を、同一術式に おいて年齡別に解析することにより、生体反応におけ る年齡因子の関与を検討した。【対象】食道癌根治術 37 例、愺頭十二指腸切除術35例、肝切除術60例、胃全 摘術45例を対象とした。【万法】手術前後に血中サイ トカイン(IL-6)、急性相反応物兵 (CRP、PSTI)、好中球 エラスターゼ(PMN-E)の測定を行い、得られたデータを 術式別、年踥別に検討した。【結果】(1)血中IL-6は術 後6時間をピークに推移し、手術侵竡が大きい術式ほど 高値を示した。(2)年齡別の検討では、術後全経過にお いて高龄者ほど血中IL-6、CRP、PMN-Eが高値を示す傾 向にあった。(3)胃全摘術では75歳以上、愺頭十二指腸 切除術では65歳以上と、それ以下にわけると、高龄者 において術後いー-6が有意に高値を示した。【結論】同 一侵震に対して高龄者が過鄱に反応している可能性が 示唆された。高サイトカイン血症は術後合併症に結び 付いている可能性があり、高龄者の手術にあたつては 低侵襲な術式を選択する必要がある。 
示-129高秢者におりる手術侵襲に対するサイト カインの反応ードレーン渗出液中interleukin- 6 及び interleukin-8 を中心に

群馬大学第一外科

塚田勝彦，竹之下誠一，長町幸雄

【目的】高齢者における手術侵億に対するI L-6及び I L-8の反応について ドレーン渗出液中で検討を加 えた。【対象及び方法】当科の消化器手術症例 52 例を 対象に 70 才以上の群 21 例（ $\geqq 70$ 群）と70才未満の 群 31 例 (<70群)に分け, 併存疾患及び術後合併症に ついて検討を加えた。更にIL-6及びIL-8 と手術時間 (OT)及び出血量 (BL)の相関について検討を加えた。 【結果】併存疾患では $\geqq 70$ 群 11 例 (52\%)と<70群 2 例 $(6 \%)$ に比し有意に多くみられ，術後合併症でも $\geqq 70$ 群 8 例(38\%)と<70群の 3 例 $(9 \%)$ に比し 有意 に多くみられた。IL-6，IL-8ともに<70群ではOT 及び B L と有意の相関を示したが $\geqq 70$ 群では有意の 相関はみられず $\mathrm{r}$ はく70群に比し有意に低下していた。 殊に 270 群では $\mathrm{BL}>1,000 \mathrm{ml}$ の患者 4 例全例が術 後合併症を併発していた。【結語】(1) $\geqq 70$ 群では $<70$ 群に比し併存疾患及び術後合併症が有意に多くみられ た。(2) ミ70群では手術侵襲に相関した IL-6及びIL8 の反応がみられず, てれが術後合併症の発生に関与 しているととが示唆された。

\section{示-130 消化器外科における手術リスクの確事式} 九州大学医学部 第一外科、*附属病院医痘情報部 吉田煩一、大谷和広、大友冝橵、赤湿宏平*、千々岩一 男、田中雅夫

く目的〉消化器外科の手術リスクを客钼化するため にその確率式を作成した。く対象と方法〉对象は消化器 疾㭧の手術を受けた121人とした。背最因子として米国

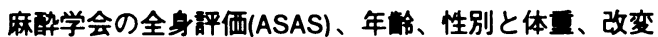
Oxfordスコアとステロイドの投与、呼吸指数をみた。結 果因子は合併症の有無とした。ロジステック回㛿法にて 有意な因子によるリスクスコアいを求め、手術リスク磼 率を $\mathrm{P}=\exp (u) / 1+\exp (u)]$ とした。く結果 $>$ 柽度以上の合 併症 $(n=46)$ に対しては $u=0.8667 \times(A S A S)+0.0043 \times$ (手術 時问)+2.626x(術刢)-8.950 となった。Pは合併症例にて $0.51 \pm 0.25$ 、非合併症例 $(n=75)$ にて $0.30 \pm 0.17$ となり、 $\mathrm{P}=0.62$ を足切り点として最も合併症の有無の予测度が 高かった。中度以上および重度の合併症についても ASAS は典要な予測因子であった。く考察〉轻症を含む 全合併症例については術㓣の大きさが䒼墨因子であり、 腹胵鏡などを用いて術㓣を縮小する努力が必要と考えら れた。く結語〉上記の確率式は手術冝後に評価可能であ り、術後管理に筑するものと思われる。
示-131 サイトカイン, 急性相蛋白からみた

Lapa-choleとOpen-choleの代期反忘の比較 姬路聖マリア病院外科

曾田益弘, 植村忠廣, 菅正人, 丸山修一郎, 吉貫憲, 村上正和, 大谷順, 唐土善郎, 山本雅彦

腹空鏡下手術は術後疼痛が少なく回復が速いなどの 利点が認められているが，その理由の解明は十分でな い。今回, Lapa-chole と Open-choleの術後の代誎反応 の比較を行った。

方法：Lapa-chole（L群）12例とOpen-chole（0群）10 例を対象とした。術前, 術後1 5日間に窒素出納, 尿 中カテコラミン，尿中 3 メルヒスチジン（3MH）， IL-6, 急性相蛋白, 安静時熱消费量, 体構成成分, 血 液ガスなどを測定した。

結果：手術時間はL群は0群より有意に長かったが, 窒 素出納および3MH排泄注L群が有意に良好で体蛋白の崩 壊の诚少が示唆された。尿中カテコラミンはL群で低 值であったが差はなかった。IL-6はL群では術後1日目 $(14.8 \pm 8.1$ vs $48.4 \pm 43.0 \mathrm{pg} / \mathrm{ml}, \mathrm{P}<0.05)$ ，3日目 $(5.5 \pm 9.0$ vs $15.9 \pm 15.4 \mathrm{pg} / \mathrm{ml}, \mathrm{P}<0.05)$ に低值を 示し, 急性相蛋白のCRP, a 1 ATも同様に低值であった。 結語 : ラパコレは開腹胆摘に比べサイトカインおよび 体蛋白の崩裹が抑制され，代謝への影繁が少ないこと が術後回復の有利な原因の一つと考えられる。

示-132 サイトカインの変動からみた肝硬変併存 肝癌切除後の病態とその問題点 大阪市立大学医学部第 2 外科

金沢景繁，木下博明，広橋一裕，久保正二 田中宏

【目的】肝硬変併存肝稳例では比較的小さな手術侵襲 にもかかわらず，術後管理に難渋することが少なくな い。そこで，これら症例におけるサイトカインの変動 からみた手術後の病態とその問題点について検討した。 【対象と方法】肝部分切除施行肝癌17例を対象とし, 周術期にサイトカインおよび急性相反応物質を測定し, それらの術前の諸因子と術後経過との関連について検 討した。【結果】肝硬変併存肝澢例の術前IL-6 值は 非併存例に比較し高值であった。術後IL-6 最高值は 術前肝予備能の不良例ほど高く, 術前IL-6 值, 総ビ リルビン, GOT, GPT の各值やICGR15分值と正の相関 が認められた。さらに術前IL-6 值が異常値を示した 症例に術後合併症が多くみられた。【結語】術前肝硬 変併存肝癌例におけるサイトカインの異常 は, 術前 から好中球やマクロファージ系細胞がすでにpriming されているか，あるいは肝細胞のサイトカインに対す る応答能が低下した結果であると推測される。このよ うな病態下では, 肝切除がsecond attackとなり, 術 後過剩なサイトカインが多臓器に影響を及ぼす可能性 が示唆された。 
示-133肝切除術後における血中IL-6の変動と その意義について

北里大学医学部外科

木村 徹、高橋 毅、飯野善一郎、伊藤義也、

古田一徳、吉田宗䄫、比企能樹、柿田 章

サイトカインは、侵襲時における生体反応発動の情報 伝達物質と考えられているが、肝切除後の変動やその 意義に関しての報告は少ない。今回我々は、障害肝、 非障害肝における肝切除術後の血中IL-6值の変動を非 障害肝非肝切除術後を対照として検討した。対象は 40 例で障害肝（A群9例）、非障害肝（B群20例）、非障 害肝非肝切除群（C群11例、全例胃切除）に分類し、 術前、術後1、3、7、14日目の血中IL-6値をELISA法

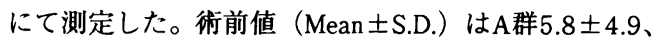
B群 $5.8 \pm 4.0 、 C$ 群 $5.8 \pm 2.3 \mathrm{pg} / \mathrm{ml}$ であった。各群とも 術後1日目にピークがみられ、それぞれ189.0土165.0、 $181.7 \pm 141.0 、 125.7 \pm 167.6 \mathrm{pg} / \mathrm{ml}$ て各群間に有意 差を認めなかった。その後各群ともに術後3日目には 速やかに減少、14日目にはほほ術前値に復した。術後 3日目の血中IL-6值はA群がB、C群に比べ高値を示す傾 向が見られた。また、術後合併症を呈した症例では血 中IL-6値の高値が持続した。今回の検討から、肝切除 術後における血中IL-6值の変動パターンは術前肝障害 や術後合併症の程度を反映することが示唆された。

示-134 肝切除症例における血中サイトカイン、 IL-6から考察した手術侵襲の評価についての検討 順天堂大学第二外科

行方浩二、岩田豊仁、須郷広之、吉本次郎、藤沢稔、 松本力雄、渡邊心、奥山耕一、渡邊勇、览島邦明、 松沢正樹、別府倫兄、二川俊二

【目的】肝切除前後のIL-6濃度の推移を測定しその有用 性を検討した。【対象・方法】肝切除症例 32例を対象と した。末梢血中のIL-6濃度 (ELISA法) を術前、術直後、 術後1、3、5、7 病日に測定した。【結果】全症例での IL-6濃度の変動は術後早期に上昇し以降減少した。IL6濃度の変動を非硬変群、硬変群別にみると両群間で変 動に差は認めなかった。IL-6濃度の変動を開胸群、非 開胸群別に見ると両群間で変動に差は認めなかった。 臨床病期別にIL-6 濃度の変動をみると臨床病期 II の症 例で、I の症例に比べて第 1 、第7病日で有意にIL-6濃 度が上昇した。術前IGCR15 と IL-6濃度の変動をみると 術前IGCR15が $15 \%$ 以上の症例で第1、第5、第7病日で $15 \%$ 以下の症例に比べて有意にIL-6濃度が上昇した。 【結語】 1 : 肝切除後、血中IL- 6 濃度は術後 1 病日に peakを示し、術後7病日目に術前值近くに復した。2： 硬変群、非硬変群または開胸の有無で、術後のpeak IL6濃度及び変動に有意差は認めなかった。3：IGCR15及 び臨床病期は術後の血中IL- 6 濃度の上昇に相関した。
示-135 サイトカインからみた手術侵墏の制御： 肝切除における周術期ステロイドパルスの効果 国立福岡東病院外科

島田光生、斉藤 純、狩野 律

【目的】今回ステロイドによる手術唚襲の制御の可能 性を肝切除例において検討した。【対象および方法】 肝切除症例19例を、対照群 $(\mathrm{n}=11)$ 、非黄疸肝群 $(\mathrm{n}=6$ : 胆汁うっ滞無くステロイド使用あり)、黄㾝肝群 $(\mathrm{n}=2$ : 胆汁うっ滞ありステロイド使用あり)の 3 群に分け、血 中の IL-6值変化および周術期の臨床パラメーターを比 較した。ステロイド使用法はメチルプレドニゾロンを 術前 3 時間前に $30 \mathrm{mg} / \mathrm{kg}$ 、術直後および術後 1 日目に 1000 mg 静脈内投与した。【結果】背景因子には差を認 めなかった。非黄㾝肝群の IL- 6 值は術直後、術後 1 日、3 日目において対照群に比し有意に低值であった (70vs 304,21 vs 227,13 vs 94 pg/ml : a ll P<0. 05 )。 一方黄疸肝群の IL - 6 值は対照群と比べ同等かむしろ 高値であった。非黄疸肝群におけろ術後 3 日目 C R P 值は対照群に比し有意に低值であった。また術後ビリ ルビン值および術後合併症においても非黄疸肝群で対 照群に比し低い傾向を認めた。【まとめ】黄疸肝の場 合を含め投与法には検討の余地があるが、ステロイド パルスにより肝切除におけるサイトカイン産生が㧕制 されるとともに手術侵襲の軽減が可能であった。

示-136輸血は胃癌術後の繾合不全を増加させる か? —多重ロジスチックモデルによる検討一 京都府立医科大学第 1 外科

大原都桂，沢井清司，金光敬祐，湊 博史，矢田裕一， 藤岡嗣朗，棉原次夫，下間正隆，北村和也，谷口弘毅， 萩原明於, 山根哲郎, 山口俊晴, 高橋俊雄

【対象と方法】対象は根治手術を行った胃癌758症例 である。方法は繾合不全を基準変数とし，(1)性，(2)年 齿, (3)術前合併症の有無, (4)病期, (5)郭清度, (6)胃の 切除範囲，(7)手術時間，(8術中出血量，(9)周手術期の 輸血の有無の 9 項目を独立变数とした。単変量解析で 有意の相関を示した独立变数を選んで, 多重ロジスチ ックモデルによる多変量解析を行った。【結果】年歯, 手術時間, 術中出血量の 3 項目について, Studentの $\mathrm{t}$ 検定を行ったところ, 手術時間 $(\mathrm{P}<0.0001)$ と術中出 血量 $(\mathrm{P}<0.0001)$ が有意の相関を示した。残る 6 項目に ついて $\chi^{2}$ 検定を行ったところ、有意の相関を示した のは輸血の有無 $(\mathrm{P}<0.0001)$ と胃の切除範囲 $(\mathrm{P}<0.0001)$ のみであった。有意の相関を示した 4 項目を独立変数 として多重ロジスチックモデルによる多変量解析を行 ったところ, 標準化係数は胃の切除範囲 $(0.4878)$, 輸 血の有無 (0.4255), 手術時間 (0.1999), 術中出血量 $(0$. 0991)の順となり, 胃の切除範囲と輸血の 2 項目が縫 合不全を增加させる有意の因子であることが判明した。 


\section{示-137消化器外科における貯血式自己血輸血 \\ 施行上の障害因子について}

秋田大学渝血部、第 1 外科*

面川 進、三浦 亮、浅沼義博k 小山研二*

[目的]同種血輸血による副作用の防止のため自己血軨血が荅入 されているが消化器外科手術で行われることは少ない。貯血式 自己血輸血施行上の問題点、障害因子を明らかにする。[対象・ 方法]貯血式自己血輸血を開始した91年7月から3年間の消化器 外科手術例。自己血貯血は予想出血量 $500 \mathrm{~m}$ 1以上、70歳以下、

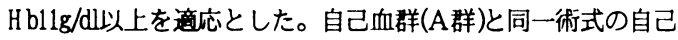
血未施行群(B群)とで術式別に比較検討。[成暴]全手術606例中 貯血式自己血輸血は $9 \%$ 、52例に施行。これらで同種血輸血例は 5例、9.6\% のみであった。胃全摘、直腸切除及び切断、肝部分 切除のA群で同種血輸血は全て回避されたがこれら手術のB群 では3380\% で同種血を使用。肝区域以上切除のB群で同種血使 用は $81 \%$ 、一方 $\mathrm{A}$ 群 $38 \%$ と有意に低い。術中出血量は全ての術 式で両群間に差はない。術前Hb値は胃全摘のA群で $14.2 \mathrm{~g} / \mathrm{dl}$ と $\mathrm{B}$ 群 $10.3 \mathrm{~g} / \mathrm{dl}$ と有意差を認めたが他の術式で差はない。B群で 末施行の理由は術前貣血か胃全摘、直腸切断で50\%にあるか、 高齢、短期術前期間などの理由は少ない。担当医の認識不足な ど患者に起因しない理由か直腸切除、肝切除で多かった。 [結語] 消化器外科でも術前貯血は術前2週間以内に $400-800 \mathrm{ml}$ 可能であった。胃癌、直腸福の術前負血以外、消化器外科で自 己血施行を障害する患者側因子は少ない。自己血輸血の推進で 消化器外科での同種血輸血は極めて高事に回避可能となる。

示-138胃癌切除手術を対象とした自己血輸血の 問題点とその解決策

滋賀医科大学第 1 外科 ${ }^{1}$ 、同麻酔科 ${ }^{21}$

寺田信國 ${ }^{1}$ ，佐野晴夫 ${ }^{1}$ ，川口 晃 ${ }^{\prime}$ ，

水谷幸之祐 ${ }^{1}$ 、柴田純祐 ${ }^{1}$ ，小王正智 ${ }^{1}$ 、

佐井義和 ${ }^{2}$ ，萬代良一2)、天方義邦 ${ }^{2}$

胃癌症例について自己血輸血の際の問題点を解析 し、その解決策を検討した。【症例】胃癌切除手術症 例209例(平成1-5年)を対象とした。これには自己血輸 血54例を更にrEP0併用症例13例を含む。貯血法27例、 希釈法24例、両者併用3例であった。【結果】(1)進行 程度が進むにつれて術前Hb値は减少し、術中出血量、 同種血輸血量は増加した。(2)自己血輸血施行群は非 施行群に比較し明かに同種血輸血量の節减ができた ( $p<0.01)$ 。(3)rEP0は軽度分血症例の同種血輸血回避に 有用であった。(4)自己血輸血を試みない症例では、 1000m1以下の術中出血でも19.1\%に同種血を施行した が、自己血輸血施行で1例のみとなり、rEP0併用で 1760ml出血例以外は同種血なしで乗り切れた。【結 論】(1)術後のQOL向上に自己血輸血およびrEPOの併用 による同種血回避は有用であり、特に進行癌を対象と して施行されるべきである。
示-139消化器外科における遺伝子組み替えヒト エリスロポエチン（r-HuEPO）を用いた眝血式自己血 輸血の試み

東京厚生年金病院、筑波大学臨床医学系外科* 野田泰永*、石原聡一郎、望月能成、武井芳樹、 坂佳奈子、松本政雄、増田幸蔵、志田晴彦、今城朋洋、 町田武久、山本登司

近年整形外科、心臓外科領域では、術中輸血として、 自己血輸血を行う症例が増えつつあるものの、消化器 外科領域においては、まだその頻度は少ない。我々は 消化器外科待機手術患者を対象に、遺伝子組み替え七 トエリスロポエチン（r-HuEPO）6000単位を週 2 回 2 週間皮下投与し、400〜 $800 \mathrm{ml}$ の自己血を術前に貯 血した。自己血貯血開始前のへモグロビン濃度は11.9 $\pm 2.1 \mathrm{~g} / \mathrm{dl}$ であったが、自己血貯血後手術前日のへモ グロビン濃度は $11.2 \pm 2.1 \mathrm{~g} / \mathrm{dl}$ で、術前の貯血にもか かわらず、貧血の進行は軽度であった。同種血輸血回 避率は80\%であり、輸血を必要とした 2 例は、術中出 血量が $600 \mathrm{ml}$ 以上の症例であった。 $\mathrm{r}-\mathrm{HuEPO}$ 投与およ び自己血輸血に関係する明らかな副作用、合併症は認 められなかった。r-HuEPOの投与量、投与方法ある いは眝血期間にはまだ検討すべき問題はあるものの、 r-HuEPOを用いての自己血貯血は、手術に必要な自 己血を限られた期間に貯血できる有用な方法であった。

示-140 術後獲得性抗組織因子抗体による prothrombin time異常症の一症例

滋賀医科大学集中治療部、同第一外科 ${ }^{11}$

江口 豊、花沢一芳 ${ }^{11}$ 、小玉正智 ${ }^{1}$

体外肝切除後、ウシ真皮由来コラーゲン製剂が免疫 原と考えられるprothrombin time (PT)異常症が報告さ れた(Blood 82:96-102,1993)。我々も同様の症例を程 験したので報告する。症例は82才男性で、喉頭癌と早 期胃癌に対し手術を施行、術中脾損傷部にウシ真皮由 来コラーゲン製剤を使用した。術後11日目より著名な PTの延長(18.8秒，19\%)が出現したが出血傾向はなく、 FFP製剂、ケーツー投与にても改善せず、15ケ月後に 術前値に回復した。PT測定を通常用いるrabbit-

tissue factor(TF)を使用すると、PT補正試験は補正 されず、患者IgGを精製 Lrabbit或はbovine-TFのTF活 性に対する阻害効果を検討すると、患者IgGはrabbit ではほぼ100\%,bovineでも78\%抑制したが、human-TFに 対しては全く抑制しなかった。精製bovine-TFをSDSPAGE後、患者IgGにてimmunoblotしたところ、42kDaの バンドを認識した。【まとめ】このPT値異常はウサ ギ、ウシは認識するがヒト組織因子は認識しない抗体 によるもので、測定上の異常なので臨床上問題はない か、PT異常時に再度の使用は禁忌と考えられ、注意が 必要と思われる。 
示-141消化器癌術前後における血中および局所の サイトカイン値の変動

大阪市立大学第一外科

池田光慶、西口幸雄、山下隆史、曾和融生

[目的]近年、サイトカインが侵襲時の生体反応の情 報伝達にきわめて重要な役割を果たしていることがわ かってきた。今回我々は、消化器瘦手術例を対象とし て、術前後の血中およびドレーン排液中の I L -6 , I L -8 を白血球数、C R P とともに測定し検討した。 [対象] 消化器癌 11 例（胃瘦 7 例、大腸㾔 4 例）を 対象とした。術後血清およびドレーン排液を探取した。 I L - 6、I L - 8はE L I S A 法にて測定した。 [結果] 血中 I L -6 値は、術当日に最高となり、そ の後すみやかに下降した。ドレーン排液も血清値と同 様の変動を示したが、その䈨度は血清よりはるかに高 かった。I L - 8は血清、ドレーン排液共に应例によ って変動が大きかったがその発現はI L - 6よりやや 遅かった。合併症をきたした例については、術後 I L -6、8ともに高値を持続した。一方 C R P は、サイ トカイン、白血球数の上昇より遅れて上年し、白血球 数の正常化の後にサイトカイン、C R P は正常化した。 [結論]サイトカインの測定は、手術侵媓の程度なら びに術後の経過とも相主し、生体への侵襲の程度をよ く反映しているものと思われた。

示-142 消化器外科症例における炎症性サイトカ インと細胞外マトリックスーフィブロネクチンの功怎 関西医科大学第 1 外科 ${ }^{1)}$, 大塚製薬株式会社工 場 ${ }^{2)}$, 大阪府母子医㞠センター研究所 ${ }^{3)}$

平松義文 ${ }^{1)}$, 豊川秀吉 ${ }^{1)}$, 豊島 茂 ${ }^{1)}$, 北出浩章1), 中川 学 ${ }^{1)}$, 上山泰男 ${ }^{1)}$, 宮下鳘—2), 坂下栄治 ${ }^{2}$, 関口清俊3)

[目的] 手術侵摬に伴う炎症性サイトカインと細胞 外 FN との相互作用の一端を解明すへく, 消化器外科 症例を対象とする臨床的検討と, ヒト正常肝細胞培羑 を用いての基礎的検討を併せて報告する。

[方法] 1994年1月以降, 当科にて手術が施行された 消化器外科症例を対象として, 術前より術後 14 日目ま での細胞型および血獎型 FN の血中濃度を測定した。 また, 初代肝細胞培䖯法によりヒト正常肝細胞での FN 合成に及ぼす炎症性サイトカイン（IL- $1 \alpha, \mathrm{IL}-1 \beta$, TNF $\alpha$, IL-6）の影謇について検討を加えた。

[結果と結論] 血漿型FN は術後推移は負の急性相蛋 白としての動態を示したが, 細胞型 FN は術後第 2 4 病日をピークとする正の急性相蛋白としての動態を呈 した。一方, ヒト正常肝細胞では細胞型 FN と血漿型 FN ともに合成されるが, 細胞型FNの合成はIL- $1 \alpha$ と IL- $1 \beta$ により有意に促進された。血漿型FN 合成は全 ての炎症性サイトカインで有意に抑制された。
示-143 外科侵撉下でのIGF-1投与の効果に対する分 子生物学的アプローチ

千葉大学第 1 外科杉浦敏之、田代亜彦、山森秀夫、 高木一也、石躍譜、下田直史、熊野祐司、大坪義尚、林 永规、古川勝規、中島伸之

【目的】熱侮ラットモデルにおけるIGF-1の肝满、小腸、 横隔膜、骨格筋の蛋白合成に対する効果をノーザン解析 により検討する。【対象と方法】7用睎の雄性SDラットを TPN管理とし、 5 日後背部皮夙に約20\%の 3 度熱䅞を作成 後、IGF-1 $4 \mathrm{mg} / \mathrm{kg} / \mathrm{day}$ を持䊦投与する群（IGF-1群, $\mathrm{n}=11$ ) としない群（対照群, $\mathrm{n}=11$ ）に分けた。2日後に镜死せし め、肝满、小腸、横隔膜、大腿四頭筋の一部を検体とし た。肝閔ではアルブミ、プレアルフミン、 $\alpha$ チュブリ ン、小腸については $\alpha$ チュブリン、横隔膜と骨格筋では 構造蛋白（ミオシン重鎖、ミオシン軽鎖、トロポニンT、 aアクチン）についてのノーザン解析を施行した。【結 果、考察】肝鹳ではアルフミンの発現量はIGF-1群で有意 に増加 $(\mathrm{P}<0.001)$ したが、プレアルプミン,$\alpha$ チュブリン は両群間に差はなかった。小腸では $\alpha$ チュブリンはIGF-1 群で有意に增加 $(\mathrm{P}<0.001)$ した。横隔膜の各々の構造蛋白 はIGF-1群で有意に增加した（ミオシン軽鎖のみP<0.05、 他はP<0.001）。一方、骨格筋ではいずれの構造蛋白の発 現量もIGF-1群で減少する傾向にあった。今回の検討によ クIGF-1の効果が㖑器、或いは各蛋白により特異性のある ことが示された。この様な分子生物学的検討によってよ り梁い病態生理の解明が可能となると思われる。

示-144手術侵㜔に伴う末梢血単球HLA-DR抗原 の変化

広島大学医学部第一外科 ${ }^{1)}$ 同 総合診療部 ${ }^{2)}$

今村祐司", 横山 隆2), 水流重樹", 佐々木 茂"), 宮本勝也"), 村上義昭 '), 山東敬弘"), 新原主計"), 桧山英三”), 竹末芳生", 坚玉 節", 松浦雄一郎'

[目的] Polkらは多発外伤患者では末梢血単球のHLADR抗原陽性率に変化が認められ，感染症の発生率や予後 と高い相関を示すと報告している。今回,消化器手術例 を対象に手術侵慗と末梢血単球のHLA-DR抗原の変化に ついて解析を行ったので報告する。

[方法]対象は胃切除術 (GC) 群4例,羘頭十二指腸切除 (PD)群5例, 食道癌根治術(EC)群5例で, 術後7日目まで単 球のCD14およびHLA-DR抗原の発現をFlow cytometryに て解析し比較検討した。

[結果] CD14抗原に各群で有意な変化を認めない。 HLA-DR陽性率はGC群で有意な変化を認めないが,PD群 $+\mathrm{EC}$ 群では術前91.7士2.3\%(mean士se)に対し,術後4時間 で79.4士9.4\%へ低下し,HLA-DR陽性単球においても術 後24時間から発現量の滅少を認めた( $<<0.02)$ 。PD,EC群 の比較でHLA-DR陽性率で術後7日目にEC群74.1 $\pm 9.0 \%$ に対し,PD群では89.3土5.1\%と回復する傾向を示した。

[結語] 手術侵裴後,末梢血単球のHLA-DR発現は一過 性に低下し,侵襲が大きくなるに従い長期間持続する。 